\author{
Silvia Laban \\ H.B.A in Architecture and Fine Art
}

University of Toronto, 2013

\author{
A Major Research Paper \\ presented to Ryerson University \\ In partial fulfillment of requirements for the degree of \\ Master of Planning \\ in \\ Urban Development
}

Toronto, Ontario, Canada, 2019

(C) Silvia Laban, 2019 


\section{Author's Declaration for Electronic Submission of a MRP}

I hereby declare that I am the sole author of this MRP. This is a true copy of the MRP, including any required final revisions.

I authorize Ryerson University to lend this paper to other institutions or individuals for the purpose of scholarly research.

I further authorize Ryerson University to reproduce this MRP by photocopying or by other means, in total or in part, at the request of other institutions or individuals for the purpose of scholarly research.

I understand that my MRP may be made electronically available to the public. 


\title{
WHERE CAN MILLENNIALS AFFORD TO LIVE WITHIN THE CITY OF TORONTO
}

\author{
(C) Silvia Laban, 2019 \\ Master of Planning \\ in \\ Urban Development \\ Ryerson University
}

\begin{abstract}
This research examines housing affordability as it pertains to millennials living in the City of Toronto. It explores literature, resale market data and planning policies to address the affordability crisis of housing in the City. It begins by a literature overview of the various definitions of affordability and examines the different historical economic methodologies used by different levels of Canadian governments. This discussion is followed by a millennial demographic analysis of the City of Toronto as a whole, and of the 25 City Wards. Housing market trends are also discussed by considering central principles and potential implications for housing affordability. An income analysis to determine affordability within select Wards is also addressed using the residual income ratio method and economic market constraints. The paper concludes by addressing the issues of affordable housing through planning policies and makes recommendations for policies that relate to the issue on all levels of government.
\end{abstract}

Key Words:

1. A paper on housing affordability issues in Toronto, used the key words: Housing, Ownership, Rental, Affordable, Resale, Toronto, Millennial, Income 


\section{ACKNOWLEDGEMENTS}

I would like to thank both my supervisor, Professor David Amborski and my second reader Kristy Shortall for their encouragement, valuable guidance, support and input throughout the process of writing the Master Research paper.

I would also like to thank Steve Keyzer and lan Gragtmans from Toronto Urban Redevelopment Advisory (TURA) at Colliers International Inc. for providing me with the support, tools and input required for the market data analysis and completion of this paper.

In addition, much regards and gratitude to all the professors, family and friends who assisted me until the end. I truly appreciate your continuous unfailing support and encouragement throughout my years of study and throughout the process of writing this research paper. This accomplishment would have not been possible without them. Thank you

Silvia Laban 


\section{Table of Contents}

1. Introduction 1

1.1 Rationale for Research 22

$\begin{array}{ll}\text { 2. Background } & 3\end{array}$

2.1 Literature Review 3

$\begin{array}{ll}2.1 .1 \text { Housing } & 3\end{array}$

2.1.2 Affordable Housing $\quad 5$

2.2 Demographic Analysis $\quad 8$

2.2.1 Millennials in the Greater Toronto Area (GTA) in 2016

2.2.2 Millennials within the City of Toronto 11

$\begin{array}{ll}2.3 \text { Housing Market } & 14\end{array}$

$\begin{array}{ll}\text { 2.3.1 Housing Market in Canada } & 17\end{array}$

2.3.2 Housing Market in Ontario 19

2.3.3 Market Analysis of the City of Toronto 23

2.3.3 (A) Ownership in the City of Toronto 23

2.3.3 (B) Rental Market in City of Toronto 25

3. Income $\quad 27$

4. Analysis and findings $\quad 30$

4.1 Affordability Analysis City Wide 36

4.2 Millennial affordability within Wards 9,10,11,13 and $18 \quad 42$

4.2.1 Ward 9 - Davenport $\quad 43$

4.2.1(A) Ownership Analysis $\quad 44$

4.2.1(B) Rental Analysis $\quad 46$

4.2.1(C) Income Ratio Analysis $\quad 48$

4.2.1(D) Ward New Housing Supply Analysis 49

4.2.2 Ward 10 - Spadina - Fort York 50

4.2.2(A) Ownership Analysis $\quad 51$ 
4.2.2(B) Rental Analysis $\quad 53$

4.2.2(C) Income Ratio Analysis $\quad 55$

4.2.2(D) Ward New Housing Supply Analysis 56

4.2.3 Ward 11 - University Rosedale $\quad 57$

4.2.3(A) Ownership Analysis 58

4.2.3(B) Rental Analysis $\quad 60$

4.2.3(C) Income Ratio Analysis $\quad 62$

4.2.3(D) Ward New Housing Supply Analysis 63

4.2.4 Ward 13 - Toronto Centre $\quad 64$

4.2.4(A) Ownership Analysis $\quad 65$

4.2.4(B) Rental Analysis $\quad 67$

4.2.4(C) Income Ratio Analysis 69

4.2.3(D) Ward New Housing Supply Analysis $\quad 70$

4.2.5 Ward 18 - Willowdale $\quad 71$

4.2.5(A) Ownership Analysis $\quad 72$

4.2.5(B) Rental Analysis $\quad 74$

4.2.5(C) Income Ratio Analysis $\quad 76$

4.2.5(D) Ward New Housing Supply $\quad 77$

$\begin{array}{ll}\text { 5. Conclusion } & 78\end{array}$

6. Recommendations - Planning Policy 79

6.1 Redefining the Term 'Affordability' to Reflect Market conditions and consistency among $\begin{array}{ll}\text { Policies } & 79\end{array}$

6.2 Addressing Shortage of Serviced Land to Increase Housing Supply in the Short Term 80 6.3 Integrating Local Market Data and Policy Density Targets to Allocate Growth BAsed on Demand

6.4 Redefining Local (City of Toronto) Planning Policies and Procedures to Address Shortage of Supply 
6.4.1 Re-assessing The Development Approval Process To Speed Development Process And Increase Supply

6.4.2 Re-Zoning Single Detached Zones Using Gentle Density to permit A Mix of Housing Typology

6.4.3 Re-Assessing Development Costs Increases Affect Development PACE and Working Through Public Private Partnerships To Increase Supply

Appendicies

Appendix A: Ward 9 Ownership Analysis

Appendix B: Ward 9 Rental Analysis

Appendix C: Ward 10 Ownership Analysis

Appendix D: Ward 10 Rental Analysis

Appendix E: Ward 11 Ownership Analysis

Appendix F: Ward 11 Rental Analysis

Appendix G: Ward 13 Ownership Analysis

Appendix H: Ward 13 Rental Analysis

Appendix I: Ward 18 Ownership Analysis

Appendix J: Ward 18 - Rental Analysiis 


\section{List of Figures}

Figure 1: Percentage of Millennial Population (aged 15-34) of the total population by Region, 2016.........9

Figure 2: Millennial Population (aged 15-34) percentage in the Greater Toronto Area (GTA), 2016.......10

Figure 3: Total Millennial Population (aged 15-34) Percentage in Toronto by Ward, 2016 ...................... 12

Figure 4: Above Average Millennial Population (aged 15-34) by Ward highlighted in red ....................... 12

Figure 5: Change in Millennial Population (aged 15-34) by Ward Between 2006 and 2016 ................... 13

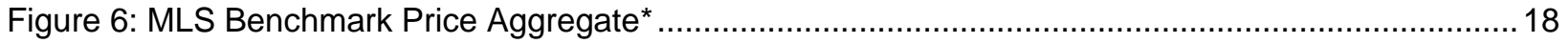

Figure 7: Sales and Average Resale Price by Major Home Type for December 2018 .........................20

Figure 8: Purpose Built Rental Vacancy Rates 1990 to 2018..............................................................21

Figure 9:Number of Market Transactions, by Dwelling Type ........................................................... 24

Figure 10: Number of Residential Units Approved and Built in Toronto from 2012 to 2016 ....................27

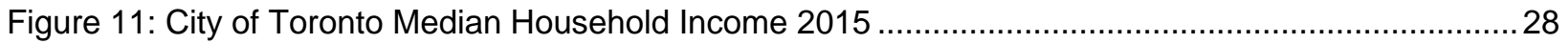

Figure 12: Comparison of Income and Wealth of Owner and Renter Households in Canada, 1984 and 1999

Figure 13: Average Net Worth of Canadian Households by Tenure Between 1984 and 2012 .................30

Figure 14: Detached House Sale Price by Submarket, Ward and Millennial Population ..........................31

Figure 15: Semi-detached House Sale Price by submarket, Ward and Millennial Population ...................32

Figure 16: Condominium Townhouse Sale Price by Submarket, Ward and Millennial Population .............33

Figure 17: Condo Apartments Sale Price by Submarket, Ward and Millennial Population .......................33

Figure 18: Row Townhouse Sale Price by Submarket, Ward and Millennial Population ..........................34

Figure 19: Co-apartment Sale Price by Submarket, Ward and Millennial Population .............................. 35

Figure 20: Co-ownership apartment Sale Price by Submarket, Ward and Millennial Population................35

Figure 21: Affordable Mortgage Based on After Tax Income Decile 2017 and Average Market Sale Price

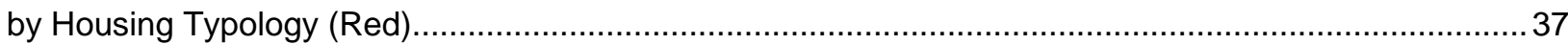

Figure 22: Affordable Monthly Rent Based on After Tax Income Decile 2017 and Average Market Rental

Price for Apartment (Red) and Townhouse (Green). 38

Figure 23: Affordable Monthly Rent Based on 2019 AMR Versus Monthly Rent Based on Q4 TREB 2018.

Figure 24: Ward 9 Profile with Overlaid TREB Submarket Boundary

Figure 25: Affordable Typologies at Average Ward 9 Income by Submarket as Recorded by TREB Market Watch 2018

Figure 26: Affordable Typologies at Average Ward 9 Income by Submarket as Recorded by TREB Market

Watch 2018.

Figure 27: Affordable Rental Typologies by Submarket as Recorded by TREB Market Watch 2018 at $30 \%, 50 \%$ and $70 \%$ of Average Ward 9 Income and Average Millennial Income. 49

Figure 28: Ward10 Profile with Overlaid TREB Submarket Boundary 
Figure 29: Affordable Typologies at Average Ward 10 Income by Submarket as Recorded by TREB Market Watch 2018.

Figure 30: Affordable Typologies at Average Ward 10 Income by Submarket as Recorded by TREB Market Watch 2018.

Figure 31: Affordable Rental Typologies by Submarket as Recorded by TREB Market Watch 2018 at $30 \%, 50 \%$ and $70 \%$ of Average Ward 10 Income and Average Millennial Income. 56

Figure 32: Affordable Typologies at Average Ward 11 Income by Submarket as Recorded by TREB Market Watch 2018. 59

Figure 33: Affordable Typologies at Average Ward 11 Income by Submarket as Recorded by TREB Market Watch 2018.

Figure 34: Affordable Rental Typologies by Submarket as Recorded by TREB Market Watch 2018 at $30 \%, 50 \%$ and $70 \%$ of Average Ward 11 Income and Average Millennial Income. 63

Figure 35: Ward13 Profile with Overlaid TREB Submarket Boundary .65

Figure 36: Affordable Typologies at Average Ward 13 Income by Submarket as Recorded by TREB Market Watch 2018.

Figure 37: Affordable Typologies at Average Ward 13 Income by Submarket as Recorded by TREB Market Watch 2018. 68

Figure 38: Affordable Rental Typologies by Submarket as Recorded by TREB Market Watch 2018 at $30 \%, 50 \%$ and $70 \%$ of Average Ward 13 Income and Average Millennial Income. .70

Figure 39: Ward18 Profile with Overlaid TREB Submarket boundary .72

Figure 40: Affordable Typologies at Average Ward 18 Income by Submarket as Recorded by TREB Market Watch 2018.

Figure 41: Affordable Typologies at Average Ward 18 Income by Submarket as Recorded by TREB Market Watch 2018.

Figure 42: Affordable Rental Typologies by Submarket as Recorded by TREB Market Watch 2018 at $30 \%, 50 \%$ and $70 \%$ of average Ward 18 Income and Average Millennial Income. .77

Figure 43: Map of Lands Designated Neighbourhood in the City of Toronto .84 Figure 44: Examples of Different Types of Homes. 'Missing Middle' Housing Can Come In The Form of Mid-rise Buildings, Stacked Townhouses, Townhouses, and Semi-detached Houses, and Can be for Sale or for Rent. .85 


\section{List of Tables}

Table 1: Toronto Average Asking Rents Compared to Average Prevailing Rents Rported by the City of

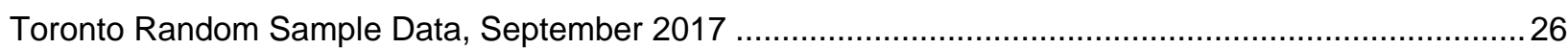

Table 2: Affordable Mortgage Based on After Tax Income Decile 2017 ................................................ 36

Table 3: Affordable Monthly Rent Payment Based on After Tax Income Decile 2017 ........................... 37

Table 4: Affordable Monthly Rent and Mortgage Payment Based Greater Toronto Area AMR 2019 ........ 39

Table 5: Income limit rates based on Greater Toronto Area AMR 2019 ................................................. 40

Table 6: Initial Income Limit Rates Based on Greater Toronto Area AMR 2019 ..................................41

Table 7: Toronto Percentage of Units Below Affordable Threshold by Unit Type, 2017 ........................ 42

Table 8: Affordable Typologies by Submarket as Recorded by TREB Market Watch 2018 at 30\%, 50\%

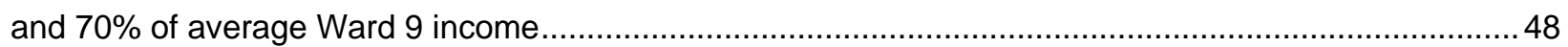

Table 9: New Housing under Construction Inventory by Dwelling Type by Neighbourhood 2018 ............50

Table 10: Affordable Typologies by Submarket as Recorded by TREB Market Watch 2018 at 30\%, 50\% and $70 \%$ of Average Ward 10 income : Affordable Typologies by Submarket as Recorded by TREB Market Watch 2018 at $30 \%, 50 \%$ and $70 \%$ of Average Ward 10 Income ...............................................55

Table 11: New Housing Under Construction Inventory by Dwelling Type by Neighbourhood 2018 ..........57

Table 12: Affordable Typologies by Submarket as Recorded by TREB Market Watch 2018 at 30\%, 50\%

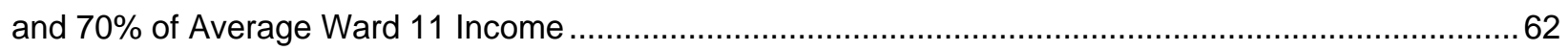

Table 13: New Housing under Construction Inventory by Dwelling Type by Neighbourhood 2018 ..........64

Table 14: Affordable Typologies by Submarket as Recorded by TREB Market Watch 2018 at 30\%, 50\%

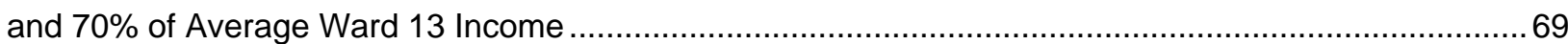

Table 15: New Housing under Construction Inventory by Dwelling Type by Neighbourhood 2018 ...........71

Table 16: Affordable Typologies by Submarket as Recorded by TREB Market Watch 2018 at 30\%, 50\%

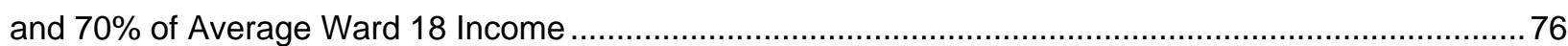

Table 17: New Housing under Construction Inventory by Dwelling Type by Neighbourhood 2018..........78 


\section{INTRODUCTION}

Housing is the single most expensive and the largest item that households have to budget for. Regardless of tenure, housing is seen to make important contributions to the current and future economic health and to the foundations of a healthy community by improving quality of life, social cohesion, and diversity balance. Not having a place to live or a home means being excluded and even exiled from the mainstream social patterns of day to day life (David $F$ Clapham, William Clark, 2012). It also means that all effort is directed towards physical survival rather than other activities, which affects the overall economic health. Thus, current and future residents must be able to access affordable housing as a measure of maintaining adequate quality of life.

This paper explores the literature relating to the concept of affordable housing and the different methods used to define it, including both ownership and rental tenures. It specifically explores affordability for millennials within the City of Toronto. Millennials in this paper are defined as those in the 25-34 age cohort, as the population growth of this cohort has experienced the most significant growth pace within the Greater Toronto and Hamilton Area (GTHA) (Petramala et al., 2018). As the population ages, their needs for affordable space over amenities and access to transit takes priority. It is expected that as this generation of millennials moves up the economic and social ladder, their needs will be similar to that of previous generations in terms of home ownership. This however has been put on hold for many due to limited housing choices caused by increase in housing cost and lack of supply (Petramala et al., 2018). This paper looks at the resale housing market trends in the City of Toronto as a major driving factor to the housing economy, while focusing on Wards that have higher than average concentration of millennial population. There are five main City Wards that were identified; Ward 9, Ward 10, Ward 11, Ward 13 and Ward 18. Using these Wards as focal points within the City of Toronto, affordable housing options by tenure and building typology are explored. Affordability of housing is tested against the average millennial income, the average Ward income, as well as income deciles as recorded by Census data 2016 using current economic and policy regulations.

The overall intent of this paper is to raise awareness and understanding of the importance of affordable housing as an important part of the overall urban economy and offers recommendations that can guide more effective bridging the gap between the market and policy in addressing the crisis at hand. 


\subsection{RATIONALE FOR RESEARCH}

Affordable housing is an essential element to the economic health of cities. While many consider increasing housing prices a consequence or a side effect to their economic success, it is in fact a myth (Bertaud, A., 2018). Unaffordability and high housing prices creates a misallocation of economic resources towards real estate which can significantly slow down economic growth and may lead to a housing bubble to burst or a freeze of investments in the economy (Bertaud, A., 2018). High housing prices also causes a lot of hardship for the welfare of households as it is one of the most significant investments a household pays for. Hence It is important to understand the role of planning policies in the way they shape and form the current state and future of our cities. In this research the City of Toronto is used as a case study to examine the question of affordability. The importance of this research is to determine how severe the affordability issue in the city of Toronto is, where is it located and how does it affect millennial. It also aims at informing readers of the gap between the planning policies and the reality of the housing market. The recommendations offered in this paper are intended to guide the city of Toronto and other levels of government to the issue of housing affordability for millennial and the greater population in general. 


\section{BACKGROUND}

\subsection{LITERATURE REVIEW}

\subsubsection{HOUSING}

In order to address the concept of housing, it is important to first define it as a term. According to the Merriam Webster dictionary, housing which originates from the term house is defined as 'shelter', 'lodging', 'dwellings provided for people'(Webster, n.d.). Similar to freedom of expression; economic, social and cultural rights, housing is considered one of the most essential basic needs of humans. According to United Nations Human Rights housing is recognized as the "basis of stability and security for an individual or family. The centre of our social, emotional and sometimes economic lives, a home should be a sanctuary; a place to live in peace, security and dignity."(United Nations Human Rights, 2019a) In fact the Universal Declaration of Human Right (UDHR) and International Covenant on Economic Social and Cultural Rights law, recognize not just housing but 'Adequate Housing' is as an inherent human right. Article 11 of the International Covenant on Economic Social and Cultural Rights law states "The States Parties to the present Covenant recognize the right of everyone to an adequate standard of living for himself and his family, including adequate food, clothing and housing, and to the continuous improvement of living conditions" (United Nations Human Rights, 1966).

The term adequate housing is defined as "more than just four walls and a roof. It is the right of every woman, man, youth and child to gain and sustain a safe and secure home and community in which to live in peace and dignity" (United Nations Human Rights, 2019b). The following are the minimum criteria and standards to which the implementation and progress of the term adequate housing is measured across the globe; (United Nations Human Rights, 2019b)

- Security of tenure: housing is not adequate if its occupants do not have a degree of tenure security which guarantees legal protection against forced evictions, harassment and other threats.

- Availability of services, materials, facilities and infrastructure: housing is not adequate if its occupants do not have safe drinking water, adequate sanitation, energy for cooking, heating, lighting, food storage or refuse disposal.

- Affordability: housing is not adequate if its cost threatens or compromises the occupants' enjoyment of other human rights. 
- Habitability: housing is not adequate if it does not guarantee physical safety or provide adequate space, as well as protection against the cold, damp, heat, rain, wind, other threats to health and structural hazards.

- Accessibility: housing is not adequate if the specific needs of disadvantaged and marginalized groups are not taken into account.

- Location: housing is not adequate if it is cut off from employment opportunities, healthcare services, schools, childcare centres and other social facilities, or if located in polluted or dangerous areas.

- Cultural adequacy: housing is not adequate if it does not respect and take into account the expression of cultural identity.

One of the most common misconceptions about the right to adequate housing is that the government is required to build housing for all the population, or that it is only related to marginalized groups (Office of the United Nations High Commissioner for Human Rights, 2014). The right to adequate housing is simply a measure that governments at various levels can use to ensure tenure for all. This can exhibit itself in legislative, administrative, policy or spending priorities.

Although Canada has signed a number of human rights treaties that support the right to adequate housing, the domestic law in Canada i.e. the Canadian Charter of Rights and Freedoms does not recognize adequate housing as a right. However, in 2012, MP Marie-Claude Morin introduced Bill C-400, which is a National Housing Strategy bill that ensures "secure, adequate, accessible and affordable housing for Canadians"(Parliament of Canada, n.d.). It also included provisions regarding providing affordable housing, which was defined as "housing that is available at a cost that does not compromise an individual's ability to meet other basic needs, including food, clothing and access to health care services, education and recreational activities" (Parliament of Canada, n.d.). But Bill C-400 was defeated in February 2013 (Canada Without Poverty, 2019). In 2018 Federal Government announced "Canada's first ever National Housing Strategy (NHS)" a $\$ 40$ billion plan that recognizes the importance of access to housing for all Canadian while being affordable and safe. The strategy also recognized housing rights as a human right. The plan aims to implement the principles of accountability and participation through setting of targets and evaluation of outcomes and recommend solutions to systemic barriers faced by Canadians in accessing affordable housing. The Strategy is grounded in principles of inclusion and non-discrimination through diverse participation, funding, and highlighting the benefits of inclusive communities (Government of Canada, 2018). On a micro 
level, the City of Toronto's Official Plan (OP), does not state that housing is a right; however it does state that "adequate and affordable housing is a basic requirement for everyone.... Current and future residents must be able to access and maintain adequate, affordable and appropriate housing"(City of Toronto, 2006). Also, the City of Toronto's housing charter states; "all residents should have a safe secure, affordable and well-maintained home from which to realize their full potential" (City of Toronto, 2017b).

In Canada almost 80 per cent of Canadian households have their housing needs addressed through the open market (Canada Mortgage and Housing Corporation (CMHC), 2018a). But since this is the case not everyone has the financial means to compete in the housing market. As the affordable housing crisis started growing within the region, on November 22, 2017 the federal government announced a ten year national housing strategy establishing that "Housing rights are human rights, everyone deserves a safe and affordable place to call home" (Peter Zimonjic, 2017). The strategy is not expected to kick in until after the next federal election, which constitutes a risk factor on if it will be implemented by the new government. The plan looks at "building 100,000 new affordable housing units, repairing 300,000 affordable housing units, cutting chronic homelessness by 50 per cent, protecting 385,000 households from losing an affordable home, providing 300,000 households with financial assistance through the Canada Housing Benefit and removing 530,000 households from housing need"(Peter Zimonjic, 2017). Hence the question arises of considering housing as a right and a commodity - what is considered affordable? How is affordability measured?

\subsubsection{AFFORDABLE HOUSING}

According to definitions form English dictionaries, affordability is defined as the state of being cheap enough for people to be able to buy (Cambridge Dictionary, n.d.), ability to afford, inexpensiveness (Oxford Dictionaries, n.d.), to manage to bear without serious detriment, to be able to bear the cost of (Merriam Webster, n.d.). Although affordability is a term often used to refer to affordable housing, these definitions demonstrate that the term affordability links people to the commodity which they wish to purchase. However, there is a distinction between market affordability and individual affordability. Market affordability is the median price of a general area, a measure that can be used by the industry to determine the feasibility of a project or predict profits. It is also useful for planners to recognize need for implementing policies to accommodate for affordable housing. Individual affordability is linked to the individual's ability to pay their mortgage without facing a cost burden (Melanie D. Jewkes and Lucy M. Delgadillo, 2010) 
According to housing literature there is no agreement on how affordability is measured (Julie Mah, 2009). Some measures of affordability are based on the household's ability to qualify for a mortgage. This method is criticized because of the leniency of mortgage rates and the credibility of lending sources (Melanie D. Jewkes and Lucy M. Delgadillo, 2010). Another way of measuring affordability is through the relative concept of housing affordability through history, also known as the relative concept measure. This method is widely used within the real estate and mortgage lending industry by basing affordability on prototypical measures from the market sales in relation to the median income (Stone, 2006). This method allows for speculation around the affordability of a house located within a given area is becoming more affordable. It also does not provide information about whether the housing is affordable or not, and which kinds of households can or cannot afford it (Cai, 2017).

Another method of measuring affordability is by looking at it from a subjective approach. This method assumes that households are rational and base their decisions on maximum efficiency. It also assumes that everyone needs a unit to live in that is considered affordable for them within their constraints. Following this logic, higher income households have more flexibility in allocating their income for housing and other needs, while low income households are constrained by their income on spending it on non-household items (Stone, 2006). Thus, all those who have a unit can afford the unit they live in and so are living in an affordable housing. This method does not advocate for any kind of policy intervention or debates for change (Cai, 2017)

A fourth approach of measuring affordability is by looking at the family budget, where Fair Market Rent (FAR) is used as the measurement for the housing expense beside all the other basic expenses which are measured against the aggregate household's income to determine if the basic income generated can support the expenses. This method is criticized to the fact that housing is "inhomogeneous" and varies in supply and price, thus a minimum standard cannot be determined. In contrast, food and other needs are elastic and can be represented by a standard monetary amount. Therefore, this methodology can specify a reasonably precise physical standard for housing, but it cannot establish a precise monetary standard (Stone, 2006).

The fifth approach is known as the residual income approach, like the family budget approach, this method is based on whether the household can afford to pay their expenses after paying their housing expenses. This implies that a household will have an affordability issue to face if it cannot meet the basic needs after paying for housing. This method is thus the difference 
between income and housing cost resulting in the residual income rather than a set ratio (Stone, 2006).

A new approach to affordability has emerged recently by the Demographic International Housing Affordability Survey, where affordability was rated for middle income housing using a method called the "Median Multiple". This method is widely used and recommended by leaders in the industry as well as by the World Bank, the United Nations and by the Joint Center for Housing Studies at Harvard University. The method uses the median house price and divides it by the median household income to determine affordability (Bertaud, A., 2018). The median multiple rating for affordable housing is at 3.0 or under, moderately affordable at 3.1 to 4.0 , seriously unaffordable at 4.1 to 5.0 and severely unaffordable at 5.1 and over.

It has become common practice to use housing cost as a ratio of income to determine affordability. The traditional rule of thumb that was used by people in the 1960s and 1970 was that people can afford to spend up to 25 of their income on housing without facing any crisis (Stone, 2004)In the 1980's this ratio increased to be 30 per cent of their income on housing. Coincidently affordable housing is defined by the Canadian Mortgage Housing Commission $(\mathrm{CMHC})$ as housing that costs less than 30 per cent of a household's before tax income. It does not only refer to rental tenure but also to ownership. This means that if households spend more than 30 per cent, they are likely to face affordability issues - the household is paying more than they can afford. On a Provincial level, the Provincial Policy Statement (PPS) 2014, affordable is defined as (Ministry of Municipal Affairs and Housing, 2014) ;

1. in the case of ownership housing, the least expensive of:

a. housing for which the purchase price results in annual accommodation costs which do not exceed 30 percent of gross annual household income for low and moderate income households; or

b. housing for which the purchase price is at least 10 percent below the average purchase price of a resale unit in the regional market area;

2. in the case of rental housing, the least expensive of:

a. a unit for which the rent does not exceed 30 percent of gross annual household income for low and moderate income households; or

b. a unit for which the rent is at or below the average market rent of a unit in the regional market area. 
The use of this ratio method has been attacked by a number of researchers such as David Hulchanski due to its limitations in accounting for factors such as household size and the relative prices of the household's other expenditures. Having a constant ratio assumes that all households are consuming households in the same manner. Although a good rule of thumb, in real life households may choose to spend more or less on housing, either out of preference or out of need for shelter. The ratio also does not consider quality of housing over time, household size and location (Melanie D. Jewkes and Lucy M. Delgadillo, 2010). Acknowledging the limitations of the ratio method, it is however used as the guiding principle for determining affordability in Canada. In Toronto it is estimated that 42 per cent of millennials pay more than 30 per cent of their income on housing cost (Janet Mcfarland, 2017)

In this paper affordable housing will be explored using the City of Toronto as a case study within a Canadian context. The concept of affordable housing is defined within the City of Toronto's Official Plan (2015) housing policies (3.2.1), the guiding policy document for the city's long-term and short-term development. The policies address affordable housing not only by defining what is affordable but also by distinguishing it by tenure - ownership and rental affordable housing. It also distinguishes between affordable rental or ownership housing, rental housing, midrange rents and social housing - refer to glossary (City of Toronto, 2006).

This paper will only address affordable housing within the City of Toronto from both a rental and ownership tenure only. The scope will not include social housing or assisted housing as affordable and will not include rental, midrange rents as part of the measuring metrics for determining affordability. However, whether buying or renting the affordability measures do not differ between who it applies to, which raise a series of questions; Affordable to whom? How much do you need to earn to afford it? in what physical standard - new or used/ resale? This paper aims to tackle these questions by looking at a specific population segment known as the millennials and adds on another layer of where these affordable units are geographically located within the City of Toronto.

\subsection{DEMOGRAPHIC ANALYSIS}

\subsubsection{MILLENNIALS IN THE GREATER TORONTO AREA (GTA) IN 2016}

The Greater Toronto Area (GTA) as a geographical boundary is comprised of the census divisions of Toronto, Durham, Halton, Peel and York. It is considered one of the fastest growing regions within the province of Ontario. According to the Ministry of Finance growth projections 
report, the GTA's population will account for over 65 percent of Ontario's net population growth to 2041 . The population within the GTA is projected to increase by 2.8 million, from 6.9 million in 2017 to reach almost 9.7 million by 2041 , which is equivalent to an increase of 33.5 percent. The forecast of the GTA's share of provincial population is projected to rise from 48.3 percent in 2017 to 52.3 percent in 2041 , passing the 50 percent mark in 2026 to 52.3 percent in 2041 (Ministry of Finance, 2017b)

Although growing at a very fast rate the GTA is expected to be one of the regions that has the youngest age structures in comparison to neighbouring regions as a result of strong international migration and positive natural increase. Growth within the region is projected to be strongest within the Central Region at 27 percent from 3.04 million 2017 to 3.87 million in 2041, which is an increase of 823,000 .

The average millennial population within each region in comparison to the total population recorded in 2016 is approximately $26 \%$, with the City of Toronto leading by 29 percent represented in Figure 1. Within the GTA, the City of Toronto's population is projected to rise from 2.93 million in 2017 to 3.91 million in 2041 , an increase of 33.5 percent, which is slightly higher than the provincial growth rate (Ministry of Finance, 2017b).

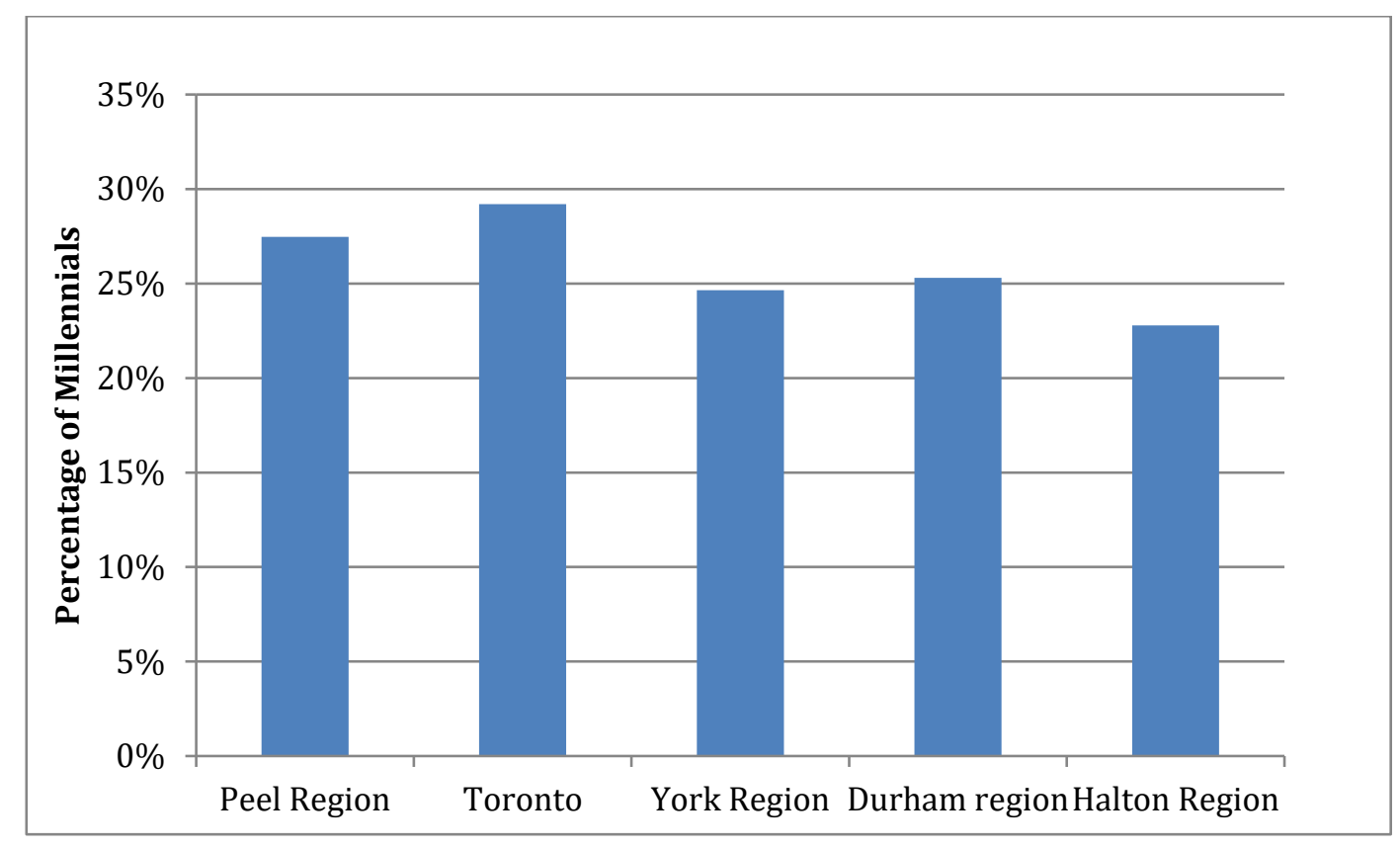

Figure 1: Percentage of Millennial Population (aged 15-34) of the total population by Region, 2016 Sources: Census Metropolitan Area Census Profile (CMA), 2016 
According to Statistics Canada -2016 GTA census profile, the total number of persons that are within the age cohort of 15-34 years old - Millennials, is estimated to be 1,739,335 million persons, which is approximately 50 per cent of the millennial population within the Province of Ontario. Figure 2 represents the percentage of millennial population by region of GTA population based on 2016 census data. In ranking the different regions within the GTA, shows the City of Toronto ranks highest in hosting the largest number of millennials $(797,800)$, followed by Peel Region $(379,585)$, and York Region $(273,605)$. Population change by age group in the City of Toronto indicates that the millennial population has increased from 704,575 to 797,800 which is approximately 12 per cent since 2006 and by 51,275 an increase of 6 per cent since 2011.

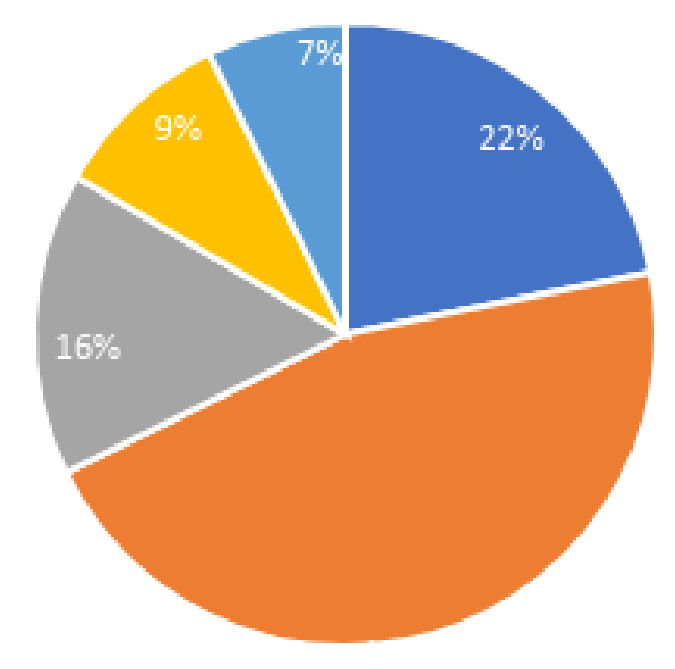

Peel Region $\quad$ Toronto $\quad$ Y York Region $\quad$ Durham region $\quad$ Halton Region

Figure 2: Millennial Population (aged 15-34) percentage in the Greater Toronto Area (GTA), 2016 Sources: Census Metropolitan Area Census Profile (CMA), 2016

Assessing the 2015 millennial population in comparison to the 2016 population, census demographics show a decline of 5 percent, which is approximately 41,200 people in the City of Toronto yet keeping it the highest ranking within the region. A demographic study on millennials in 2015, conducted by the Ryerson Centre of Research and Land Development stated that although the City of Toronto houses most of the millennial population, approximately 55 per cent live in the 905 regions (F. A. Clayton, 2015). 


\subsubsection{MILLENNIALS WITHIN THE CITY OF TORONTO}

Since the City of Toronto is leading in hosting a significantly high concentration of millennial population within the region, it becomes a very interesting case study in analyzing where within the City of Toronto millennials reside? Are there areas with higher concentrations than others? If so, where are these areas? This section will consider the 'where' questions by taking a deeper analysis of the newly formed 25 City Ward boundaries as the geographic boundaries. Ward Profiles are prepared by the Research and Information Unit of the Strategic Initiatives, Policy and Analysis Section of the City Planning Division. They contain information regarding population gathered from Statistics Canada Census of Population, which is conducted every five years. The Ward Profiles provide a portrait of the" demographic, social and economic characteristics of the people and households" within each City Ward (City of Toronto, 2019d). The 2016 Ward Profile information is based on custom tabulations of the long form questionnaire i.e. the 25 per cent sample of the population in private households who received the long-form questionnaire. The 25 Ward Profiles are reflective of the $2018-2022$ term of City Council, which came into effect December 01, 2018.

Based on the 2018 Ward profiles, the average percentage of millennials across the city is approximately 29 per cent. However they are not equally distributed across the city. Figure 3 represents the percentage of millennial population in each ward based on the 2016 census data. Ward profile analysis show that 5 Wards, which is 20 per cent of Wards have a higher than average concentration of millennial population, with Ward 10 leading at 52 per cent, Ward 13 at 41 per cent, Ward 11 at 39 per cent, Ward 9 at 34 per cent and Ward 18 at 33 per cent. Looking at this spatially, a clear pattern between Wards $9,10,11,13$, and 18 is seen as they are clustered together, while Ward 18 is an outlier - Figure 4. 
Figure 3: Total Millennial Population (aged 15-34) Percentage in Toronto by Ward, 2016 Sources: Ward Profiles, 2016 Census

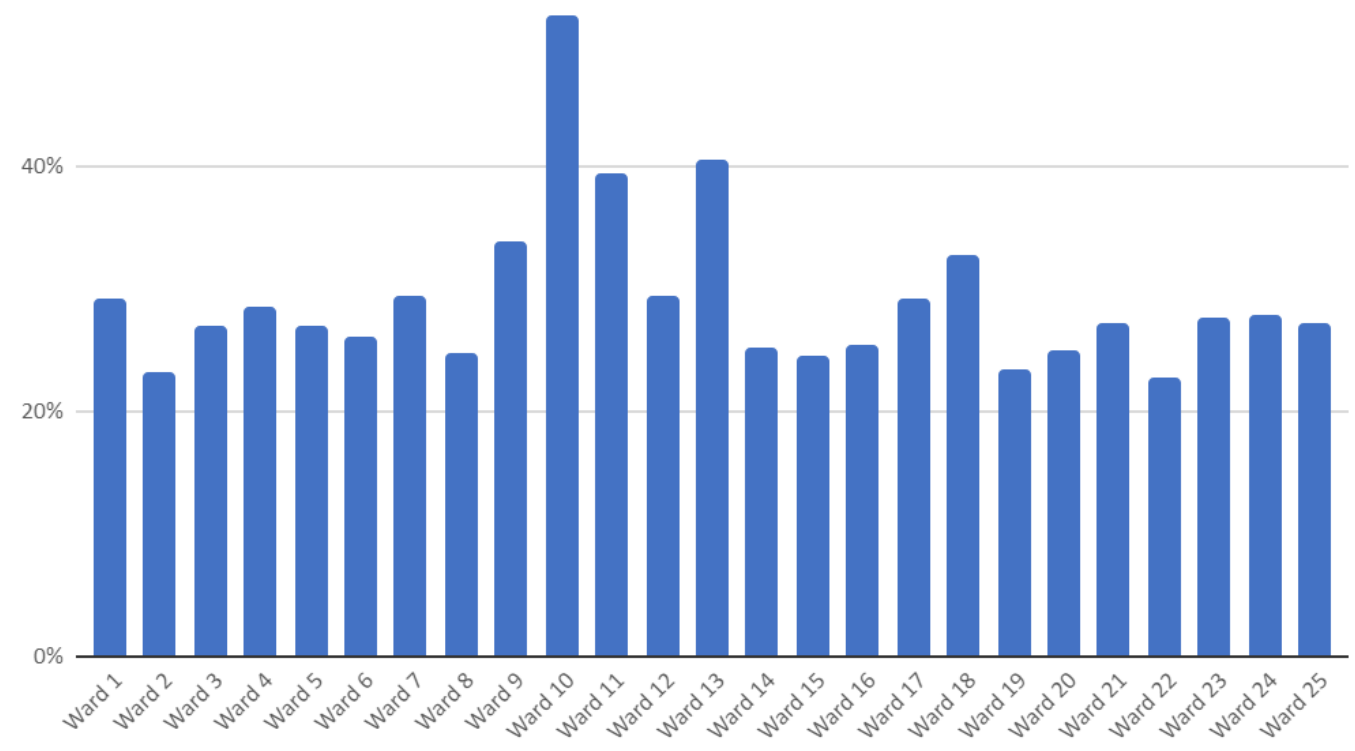

Figure 4: Above Average Millennial Population (aged 15-34) by Ward highlighted in red Sources: Ward Profiles, 2016 Census

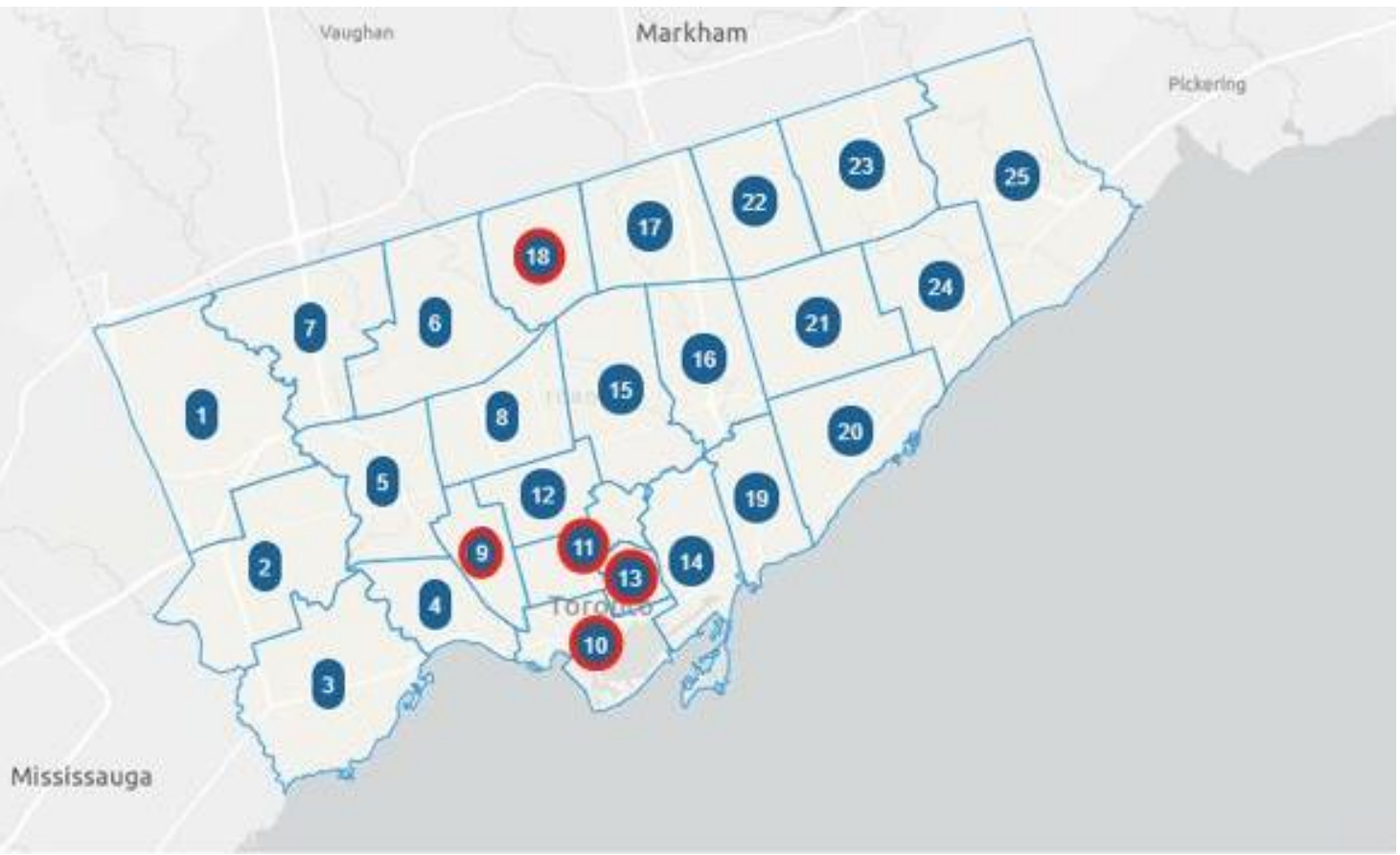

Comparing millennial demographics within the Ward from 2006 to 2016, it is evident that some Wards have seen a striking increase in populations while others have either remained constant or decreased. Figure 4 represents the change in millennial population (aged 15-34) between 
2006 and 2016. Interestingly Ward 10 has seen a significant increase of 10 percent of millennial population within the last 10 years. While Wards $13,11,9$ and 3 have seen relatively similar increase at 2 per cent to 3 per cent and Ward 14 is at a slightly higher rate at 4 per cent. Wards such as $24,21,17,2$, and 1 have seen a slight increase of only 1 per cent, while the remaining Wards; $5,6,7,8,15,16,18$ and 23 have been stagnant at 0 per cent change in growth rate.

Figure 5: Change in Millennial Population (aged 15-34) by Ward Between 2006 and 2016.

Positive Change in Millennial population above 4\% (Green), 1\% - 2\% (Orange), 3\%-4\% (Yellow), 0\% (Clear) and Negative (Red).

Sources: Ward Profiles, 2016 Census and 2006 Census

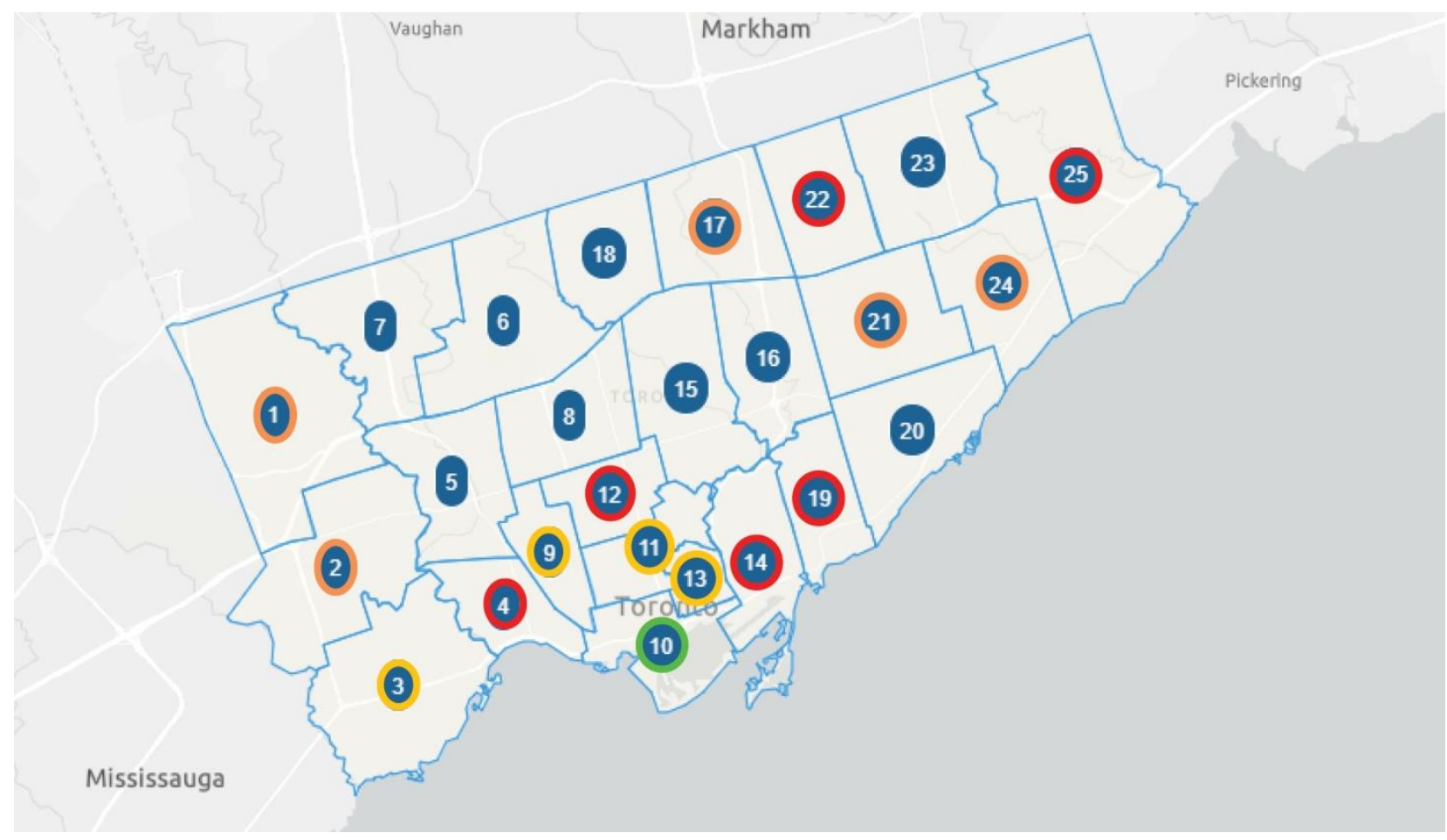

\begin{tabular}{|l|l|l|l|l|l|l|l|l|l|l|l|l|l|l|l|l|l|l|l|l|l|l|l|l|l|}
\hline Ward No. & 1 & 2 & 3 & 4 & 5 & 6 & 7 & 8 & 9 & 10 & 11 & 12 & 13 & 14 & 15 & 16 & 17 & 18 & 19 & 20 & 21 & 22 & 23 & 24 & 25 \\
\hline 2016 - Millennial population (\%) & 29 & 23 & 27 & 28 & 27 & 26 & 29 & 25 & 34 & 52 & 39 & 29 & 41 & 25 & 25 & 25 & 29 & 33 & 23 & 25 & 27 & 23 & 28 & 28 & 27 \\
\hline
\end{tabular}

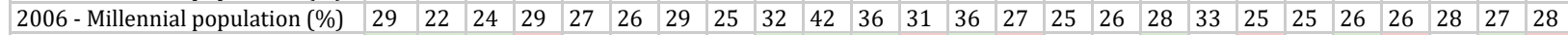

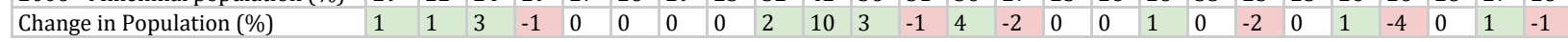

Analyzing this data spatially, it shows that the Wards experiencing the most growth are surrounded by those that are experiencing the decline. Figure 5 represents the change in population between 2006 and 2016 geographically. In other words, over the past 10 years, there has been a significant shift of millennial population towards the core which could be a result of many factors such as the availability of employment opportunities, gentrification and construction of new housing stock, quality of life, etc. 


\subsection{HOUSING MARKET}

Going back in history, the 'market' was traditionally referred to as a location or a venue through which goods were sold by sellers and bought by their prospective buys in exchange for payment. However, over time the idea of a single geographical location was challenged as markets began to develop and spread in different areas and products were created that relate to their consumers (David F Clapham, William Clark, 2012). Although in Canada, health and social welfares are recognized as systems. When it comes to housing it is recognized as a market. This implies a non-governmental activity, and treats housing as commodity, which exists in its current form due to public policies and programs (Young \& Leuprecht, 2006). In deconstructing the definition and identifying what is the housing market, it is fundamental to acknowledge that housing is a commodity within the market that is consumed by its users.

Similar to any commodity, from an economic perspective, housing is made up of a number of physical characteristics such as constructed space using different materials and components using capital, land and labour. It is complex in nature with multiple attributes and is consumed by its consumers jointly with the neighbourhood characteristics that surround it. One of the very common methods that have been used for the past decades where these characteristics are measured is the Hedonic pricing method. This method identifies the economic significance of the main characteristics and attributes which include (David F Clapham, William Clark, 2012);

1. Housing is heterogeneous, which means that it varies by size, style, layout, place, location and variety of provided amenities and location, which includes;

a. The costs of accessibility other locations used by household such as employment, shopping and leisure locations

b. The quality and availability of neighbourhood amenities, including neighbours

c. Access to both public and private local retail and service facilities

2. Housing is durable, which mean that its quality and asset value of the house is relative to potential gain and loss over time, as well as the quality and state in which maintenance is required for the asset.

The method is simply an estimation of the amount a buyer is willing to pay for each characteristic per square footage. The model takes into account non-market goods such as proximity to good views, schools and neighbourhood characteristics as goods that impact value. The heterogeneity characteristic that applies to housing has a number of implications on the 
market process and structures. The first implication is that a household's wellbeing is directly linked to the influence of these characteristics, which means that housing cost has a significant effect on household budgets. It is important to note that the characteristic of housing varies by type and place, which means that consumers will differ by age, income, preferences, etc. This raises the question of which product type is best for which type of consumers? (David $F$ Clapham, William Clark, 2012).

The second implication is related to the unique characteristics of housing being immobile, which means that its customers (renters or owners) are the ones that need to move around in order to consume the product. However moving is a costly process and requires capital and consumers to be well informed, thus making it a more complex equation for relocation. Consumption of housing may not only based on its characteristics or capital, it can be driven by the desire to own or occupy a specific structure or space within a specific neighbourhood, i.e. non market good, based on the neighbourhood character and social standing of the area. Many people tend to choose to purchase houses within neighbourhoods that have people with similar social attributes as themselves. Hence neighbours become a significant factor in determining neighbourhood quality. This specific attribute is specifically important as it is reflected in economic terms of vacancy rates, means of prices and neighbourhood demographic composition. The immobility of a dwelling combined with its durability means that owners face both the risk of depreciation and loss of the value of their home as well as the potential appreciation and gain in value, both of which are beyond the consumer's control. Hence geography and time are the elements used in combination to inform expected pricing of an area, an important feature of the way in which the housing system operates (David F Clapham, William Clark, 2012).

Urban economic analysis of the housing market explores two forms in which housing market operates; the asset market and the space market. In exploring the asset market, supply of new assets is promoted through the construction sector. The amount of assets supplied is typically dependent on the price relative to the cost of replacing or constructing an asset that is identical. In the long run the asset market should equate the market prices with replacement costs, including the cost of land. However in the short run the market price and replacement costs may diverge to factors such as change in preference for housing typology, increase in labour wage or construction material prices, governmental taxes etc. Supply pricing is elastic in nature, where an increase in the price of supply acts as an incentive to the increase the quantity supplied by encouraging the building of new stock due to its profitability, and increase 
maintenance or upgrade of existing building. The elasticity of housing supply is however impacted by the availability of developable land and land use regulations.

On the demand side, the most influential determinant is the income which a housing asset can earn. The price of the asset is equal to the present value of all future cash flows, i.e. rent payments. Demand is generated through the space market, by households demanding occupancy of space. The household demand for space is typically dependent on income and cost of occupying the space in relation to the cost of other non-housing commodities such as food, clothing, etc. Thus assuming all the variables are constant and supply is fixed, when the number of households increase, the demand for space will increase causing the price of housing to rise.

Similar to supply, demand pricing is elastic in nature and changes based on the impact of a change in housing prices on the quantity of housing purchased. As household's incomes or price of housing changes, households adjust to the amount of housing they can consume. Both housing prices and demand pricing change over time due to a number of factors such as household income, age, size, etc.

$$
=\frac{\% \text { change in quantity demanded }}{\% \text { change in price }}
$$

Thus one of the factors affecting affordable housing is the existing housing stock (supply) within the market. Lack of supply in the resale housing market may lead potential buyers to meet their housing needs through the new housing market. Reduced demand for existing homes results in excess supply even in the absence of new construction. Hence the resale market plays an important role in determining the pricing of housing within the market as it directly affects supply. As household compositions change or a shift in location occurs, a potential mismatch between supply and demand occurs. This mismatch will not be representative of the urban housing market but may vary at the neighbourhood scale (David F Clapham, William Clark, 2012). The issue thus varies by income and geography. The following sections of the paper will explore the housing market especially from a purely resale perspective and not new housing at different scales of geography, with a particular focus on the City of Toronto's re-sale housing submarket, in order to identify the issues and benefits of each submarket in relation to each other and to millennial income. 


\subsubsection{HOUSING MARKET IN CANADA}

In every country, housing systems have been dealt with in various forms with different levels of government. In Canada, federal and municipal governments have played major roles in shaping the way in which Canadians meet their housing needs. The Canadian Mortgage and Housing Corporation $(\mathrm{CMHC})$ is the federal crown corporation responsible for administering Canada's National Housing Act. It is the responsible authority for contributing to the stability of the housing market and financial system by helping Canadians meet their housing needs (Canada Mortgage and Housing Corporation (CMHC), 2019). CMHC has a long history of working towards providing housing to improve the lives of Canadians. CMHC was created in 1946 and was called the Central Mortgage and Housing until 1979. It was initially created as the successor of the Wartime Housing Corporation. After the Second World War, CMHC's goals were concentrated on providing housing for returning war veterans. From the 1950 s to the 1960s CMHC's mandate was to provide sufficient amount of housing and improve housing quality through urban renewal programs (Ann Mcafee, 2006). It focused almost exclusively on home ownership through the use of public funds. In 1954, the Mortgage Insurance Fund (MIF)was introduced, which helped most first home buyers to obtain a mortgage (David Hulchanski, 2003). In the 1970s maintenance and improvement of existing programs was conducted through neighbourhood improvement programs and residential rehabilitation programs. Managing the MIF remained until today as one of the major functions of CMHC (Ann Mcafee, 2006).

Today CMHC's goal is to "make housing affordable for everyone in Canada", by helping Canadians gain access to suitable affordable housing through providing services such as mortgage loan insurance, affordable housing, first nation housing (Canada Mortgage and Housing Corporation (CMHC), 2019). CMHC also publishes reports on assisted housing mortgage insurance, securitization and covered bonds activities, housing research and statistics. Through the first three quarters of 2018, CMHC reported the updated housing statistics across Canada to reflect the following (Canada Mortgage and Housing Corporation (CMHC), 2018b);

- Delivery of more than $\$ 1.9$ billion to create housing units for low and middle income Canadians including on-reserve;

- Provided mortgage insurance for 171,173 homes across Canada, including approximately 94,000 home buyers and more than 77,000 rental units. 
- Provided more than $\$ 118$ billion in guarantees through its various securitization programs.

- Continuing to implement the National Housing strategy initiatives to build research capacity in the housing sectors, while making surplus federal lands and buildings available for affordable housing.

In terms of resale market, statistics released by the Canadian Real Estate Association (CREA) on February 15, 2019 showed that the national residential sales activity in Canada between December 2018 and January 2019, increased by 3.6 per cent. The MLS Home price index (HPI) also increased by 0.8 per cent year over year in January, while the average sale price decreased by 5.5 per cent year over year in January. The national average stock was recorded at 5.3 months of inventory by the end of January 2019. Figure 6 represents the benchmark price by tenure. Price increase on a national scale was recorded by apartment units at 3.3 per cent, followed by townhouse/row units at 1.5 per cent, and two storey single family house at 0.1 per cent. In contrast one storey single detached was decreased by 1.1 per cent (Real Estate Association (CREA), 2019).

Figure 6: MLS Benchmark Price Aggregate* Sources: CREA National Statistics 2019

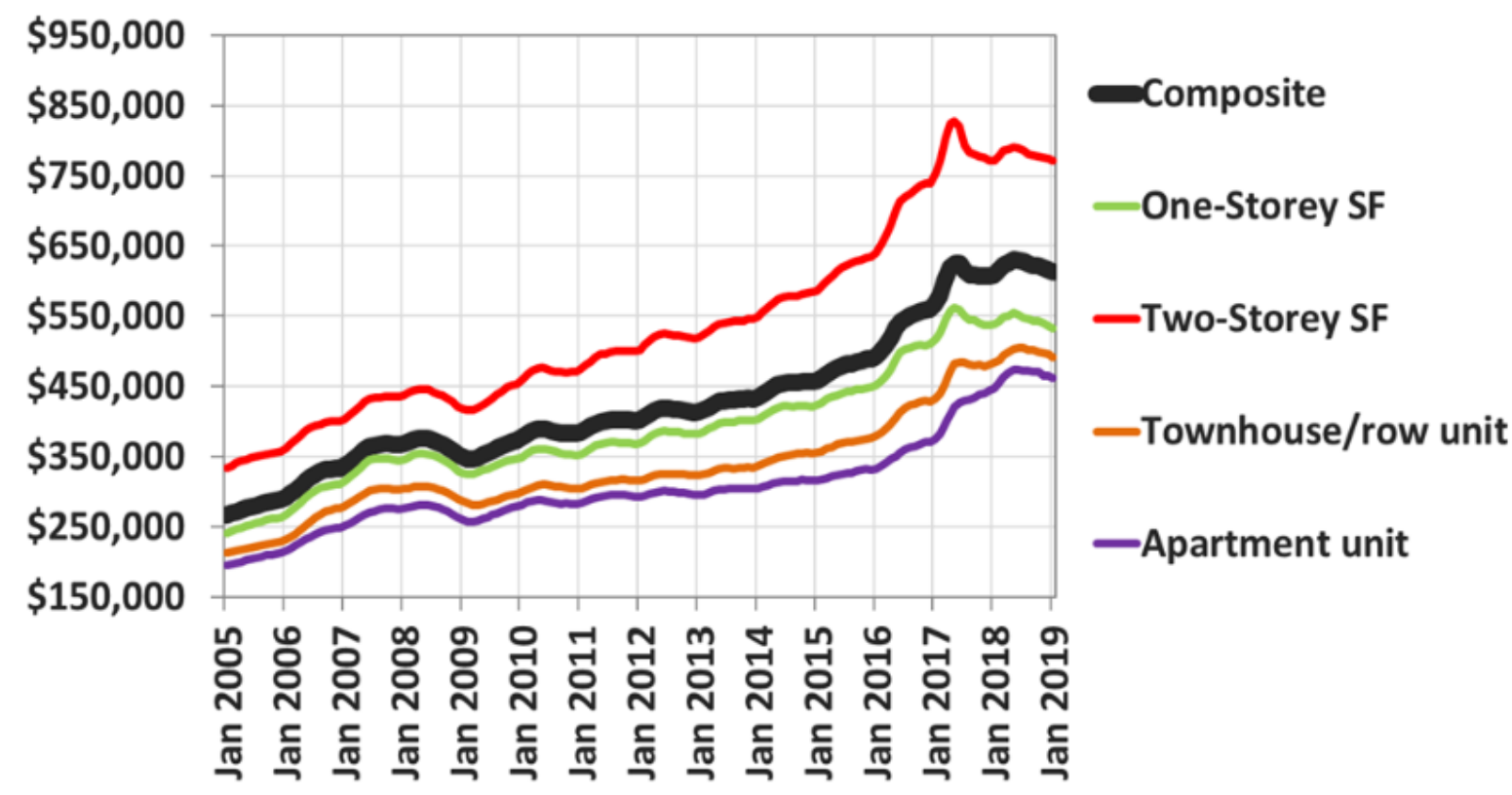

\footnotetext{
* Vancouver Island, Victoria, Greater Vancouver, Fraser Valley, Calgary, Edmonton, Saskatoon, Guelph, Hamilton-Burlington, Oakville-Milton, Barrie \& District, Greater Toronto, Niagara Region, Ottawa, Greater Montreal, and Greater Moncton
} 
According to a 2014 global investor pulse survey conducted by money manager BlackRock Inc., Canadians feel that they are "in a financial squeeze - hard pressed to save amid what they perceive as a high cost of living, including devoting much of their income to paying for their homes." (BlackRock Asset Management Canada Limited, 2014). Responders to the survey stated that on average, they spend 43 per cent of their income on housing costs. By the third quarter of 2018 the 43 per cent has increased to an average of 53.9 per cent of typical household income to carry through housing costs of an average home bought in the last quarter of 2018. Thus creating a housing affordability crisis on a national level (Wright \& Hogue, 2018). On a local level in the City of Toronto, the average share of income a household needed to spend to cover ownership costs was recorded at 75.3 percent.

\subsubsection{HOUSING MARKET IN ONTARIO}

The Ontario housing market is very reflective of the Canadian national market, where dramatic increase in pricing of housing market has been observed over the years. The provincial average price of homes rose by 29.5 per cent in March 2017 compared to 2016. In terms of housing supply, new listings made up an increase of 4.9 per cent from 2016, while on the demand side residential sales formed an increase of 20.8 per cent compared to earlier year. This left an inventory stock of approximately 1.3 months by March 2017, a decrease from 2.4 months recorded in March 2016. Thus it is no surprise that the average price for homes was recorded at $\$ 672,584$, which is an increase of 29.5 per cent from 2016 (Ontario Real Estate Association (OREA), 2019). According to the Toronto Real Estate Board (TREB) Market Watch released December 2018, the reported total sales of residential transactions were a total of 77,426 in the GTA. This is 16.1 per cent decline from the number of sales reported in 2017 at 92,263 . The average selling price across the region was at $\$ 787,300$, a reduction of 4.3 per cent year over year for all home types (Toronto Real Estate Board (TREB), 2018). 
Figure 7: Sales and Average Resale Price by Major Home Type for December 2018 Sources: TREB Market Watch 2018

\begin{tabular}{l} 
December 2018 \\
\cline { 2 - 7 }
\end{tabular}

The roots of the housing affordability issue within the market can be traced back to a number of sources. The first being historical supply of housing stock. In the GTA, the majority of the affordable rental housing was built prior to 1972. After 1972, the Federal Government imposed tax rules, deductions of upfront soft cost, and the practice of "pooling, which allowed rental owners to avoid the recapture of the Capital Cost Allowances (CCA)" (NBLC, 2016). In addition to that, 50 per cent of capital gains on rentals after 1972 were considered as income for tax purposes. The tax levies imposed were however only implemented on rental properties while owned properties were exempt (Ministry of Finance, 2017a). The tax treatments of soft costs were also changed, which have further reduced the appeal of investment in the affordable rental market. Accordingly since 1972 very little investment has been made in this sector, despite the increasing demand. In 1992 the government announced the introduction of the Home Buyer's Plan in the budget which allowed house buyers to use "up to $\$ 20,000$ in tax sheltered retirement savings as part of their down payment" (David Hulchanski, 2003).

The Federal government also ended all social housing programs in 1993 and introduced a temporary program called the First Home Loan Insurance program. This program allowed mortgage insurance to be issued by $\mathrm{CMHC}$ up to 95 per cent of the value of the house. This meant that the minimum down payment for first home buyer could be as low as 5 per cent instead of the previous 10 per cent. The program was later established to be permanent in 1998 and was no longer limited to first home buyers (David Hulchanski, 2003). This helped increase demand within the housing market dramatically but due to the lack of new supply being built at the same rate as the demand, the available stock increased in price, making it unaffordable with time. Figure 8 represents the purpose built rental rates from 1990 to 2018 demonstrating an 
evidence of supply shortage. Also with the recession in 2008-2009, housing supply became further in shortage, pushing housing prices to increase as competition for limited supply and increased demand prevailed. The average supply of single housing dwellings has decreased within the last 10 years by 74 per cent across the GTA (Toronto Region Board of Trade, 2018)

Figure 8: Purpose Built Rental Vacancy Rates 1990 to 2018

Sources: CMHC (Rental Market Survey)

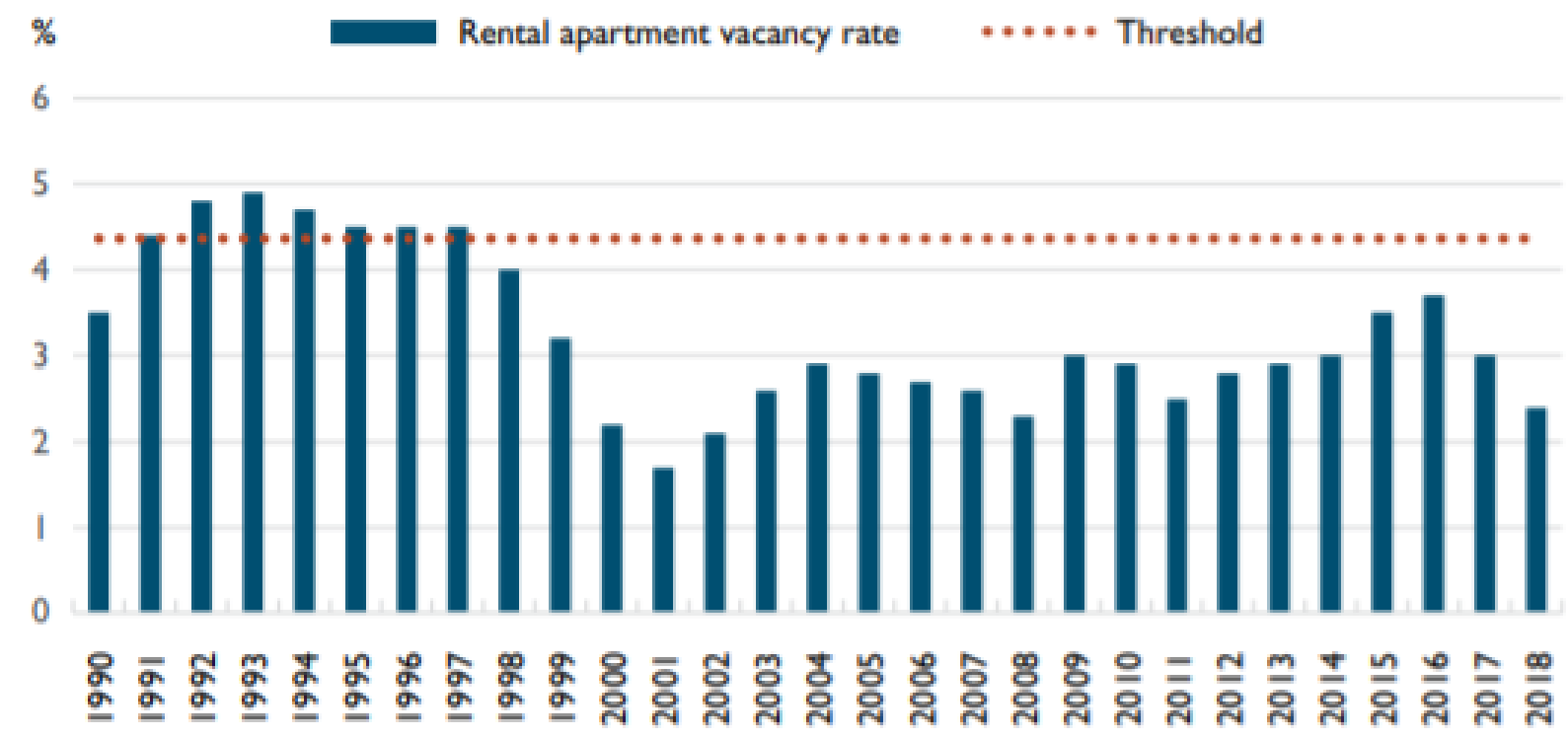

In reaction to the housing market in Ontario, the Ministry of Municipal Affairs and Housing introduced the Ontario Fair Housing Plan in April 2017. The Plan aimed at introducing measures to stabilize the real estate market by increasing housing supply to help people find affordable homes and to protect buyers and renters. To help support the supply and the demand side, the plan introduced a new 15 per cent non-resident speculation tax (NRST) on homes purchased within the Greater Golden Horseshoe (GGH) by non-citizens or foreign entities. The NRST also applied to transfer of land that contain at least one and not more than six single family residences, but does not apply to land including multi-residential rental apartment buildings, agricultural land or commercial/industrial land. The concept of the tax is to limit the demand of foreign buyers and give a chance to the local population to find more affordable and available housing stock (Ministry of Finance, 2017a).

Other actions developed by this plan to increase supply included; leveraging surplus land to develop a mix of market housing including affordable housing, introducing legislation that allows the City of Toronto and other cities to introduce vacant homes property tax. The Plan also 
amended the Planning Act and the Development Charges Act to support second units within existing housing to increase supply. On the rental supply side, the Plan introduced a targeted $\$ 125$ million five year Development Charges (DC) Rebate Program to encourage construction of new rental buildings (Ministry of Finance, 2017a).

The Plan also took into account a measure of protecting renters by expanding rent control to all private units within the province including those built after 1991. This means that landlords were only permitted to increase rent on annual basis to a maximum rate of 2.5 per cent as posted by the annual provincial rent increase guideline. It also modernized the current Land Transfer Taxes to reflect the market and doubled the maximum Land Transfer Tax Fund for eligible first home buyers to $\$ 4,000$. This meant that eligible first home buyers are exempt from paying the Land Transfer Tax in Ontario on the first $\$ 368,000$ of the cost of their housing (Ministry of Finance, 2017a).

Another major player that has greatly affected affordability today, are the increases in mortgage interest rates. This stems from the changes made to the Canadian mortgage and housing rules to introduce the Mortgage Stress Test. This change was a result of the rise of housing prices and household debt problem of purchasing houses that they cannot afford in the future. The stress test originally applied to people who made a down payment of less than 20 per cent and therefore required mortgage insurance. However as of October 17,2017, the stress test applied to all Canadians even if their down payment was 20 per cent or more (Loans Canada, 2019). The aim is to test if a potential homeowner would be able to pay their mortgage payments in the case that the interest increases without facing financial emergencies. The way that the stress test works is that if the purchaser qualifies for 20 per cent or more, the minimum qualifying rate will be based on the higher rate of either the bank of Canada's five year benchmark rate, currently at 5.34 per cent or the rate offered by the bank or lender plus 2 per cent (Bank of Canada, 2019). So to compare affordability prior to and after the stress test, if the household has an income of $\$ 87,000$ and made a down payment of 20 per cent, they would have been able to afford ( based on a maximum of 30 per cent of income affordability rate) a maximum house purchase price of $\$ 575,000$ ( based on 2.99 per cent rate). While under the stress test the same household can only afford a maximum purchase price of $\$ 425,250$, which is 21.3 per cent less than the purchase price under the old rules - see appendix (Bank of Montreal (BMO), 2018). 
According to TREB Market Year in Review \& Outlook Report 2019, on average the stress test meant that home buyers in 2018 had to qualify for an approximate $\$ 700$ monthly mortgage that what they would have payer prior to the application of the test (Toronto Real Estate Board (TREB), 2019). Although the Ontario Fair Housing Plan aimed to bring stability to the real estate market, the increase in housing prices and mortgage rates along with the stress test made home ownership out of reach for the majority of potential first-time buyers. As affordability in the ownership market diminishes the demand for rental housing has begun to increase.

\subsubsection{MARKET ANALYSIS OF THE CITY OF TORONTO}

The Canadian market data shows that the Canadian demography is divided into two major groups by tenure - Owners and Renters, each very different in nature and affordability yet complementing each other through a substitution effect. On average in 2016, 67.8 per cent of Canadian households own homes, with more than 40 per cent of the homes are owned by households under the age of 35 years old. In comparison to the national average, in the City of Toronto 66.5 per cent of the population owns households, with 38.9 per cent of households aged less than 35 years old. On a global scale the City of Toronto ranks second highest in home ownership rate at 66.5 per cent in 2016 second to Calgary at 71.9 per cent (Hogue, 2019). Considering the multiple factors affecting affordability of housing 63 per cent of the housing ownership market type is condo,20 per cent is home owner, while 17 percent is recorded rental (Canada Mortgage and Housing Corporation, 2019).

\subsection{3 (A) OWNERSHIP IN THE CITY OF TORONTO}

Homeownership is "one of the most significant investments made by individual Canadians" from 1980s to mid 1990's, ownership rates decreased for young adults due to high interest rates and recessions that took place in 1980's and 1990's (Hou, 2010). After the 1990's ownership rates saw an increase, as the interest rates were much lower and therefore individuals could afford the cost of borrowing. With CMHC making the First Home Loan insurance program and the Home buyer's plan in 1998 permanent, homeowners were able to obtain mortgages at a very small down payment. The programs insured mortgages up to 95 per cent of the value of the house. From 1971 to 2006 ownership rate for households whose primary maintainers aged 20 and over increased from 60 percent to 69 per cent (Ormiston, 2014). In terms of millennials aged 20-24 ownership rates for non-family individuals increased from 12.5 per cent in 1971 to 60.4 per cent in 2016, an increase of 48 per cent in 35 years (Hou, 2010). 
Income is also closely related to the increase in homeownership since 1971, where the trend increased in the upper-income quintiles and declined among households in the lower 20 per cent of the income distribution. This created a large gap between ownership across different income distributions especially among the age group of 20-34. In 1971, homeownership among the top quintile was higher by 23 per cent, and increased to 119 per cent in 1981, and finally reaching 300 per cent in 2006 (Hou, 2010).

According to TREB Market Watch December 2018, total sales of residential transactions for all home types in the City of Toronto, was recorded at a total of 29,863 , which is equivalent to 39 per cent of the region's total sales. The average re-sale price for all home types across the City in 2018 was at $\$ 835,422$ with a median price of $\$ 665,000$. Figure 9 represents the number of transactions average and median price by dwelling type. Of the total sales, 340 transactions were detached houses at an average sale price of $\$ 1,145,890,116$ semi-detached at an average sale price of $\$ 939,859,114$ condominium townhouses at an average sale price of $\$ 652,7787,848$ condominium apartment at an average sale price of $\$ 594,381,1$ link at an average sale price of $\$ 863,000,48$ attached/row/townhouse at an average sale price of $\$ 860,930,3$ co-op apartments at an average sale price of $\$ 889,167,0$ detached condominium, and 3 co-ownership apartment at an average sale price of $\$ 471,667$. According to $\mathrm{CMHC}$ Housing Market Information Portal both the detached and semi-detached tenure are experiencing decline in number of transactions from 2017 while row townhouses and apartments are experiencing growth. Figure 9 shows the average and median prices recorded by TREB for 2018 by tenure (Toronto Real Estate Board (TREB), 2018).

Figure 9:Number of Market Transactions, by Dwelling Type Sources: TREB 2018 Market Watch

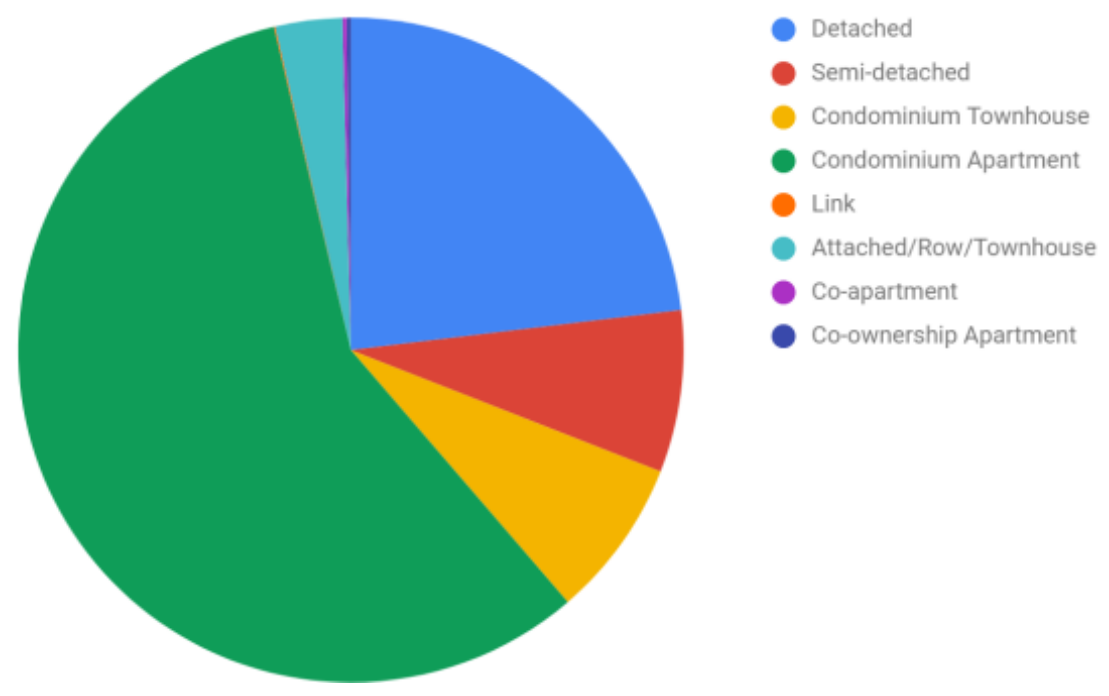




\subsection{3 (B) RENTAL MARKET IN CITY OF TORONTO}

According to a study conducted by Nepstick (a database for furnished apartment rentals) in 2017 on major cities around the world to determine the top 110 millennial dream destinations, the City of Toronto ranked $5^{\text {th }}$ best city. The study conducted looked at data provided by organizations like the UN, the WHO, Euromonitor, Crunchbase and the U.S. Bureau of Labour. Although ranked $5^{\text {th }}$, the City of Toronto scored a low of 2.7 out of 10 for housing, showing that the local housing crisis is now becoming known to the world (Nepstic, 2018). The 2018 Rental Toronto Housing Market Conditions in Toronto stated that 47 per cent are renters with an average of 47 percent of the renters spend more than 30 per cent of their income on housing. It also stated that only an estimate of 50 percent of the rental housing stock that is in the city is purpose built rental (City of Toronto, 2018a). One in five Toronto residents "live in housing they cannot afford, that is too small for their needs, or that requires significant repair" (Cohrs, 2014).

In 2016 CMHC Affordable housing market report stated that there was an increase of the average rental rate of a multiple family dwelling unit from 2015 by approximately 9 per cent which is higher than the 3.2 per cent in 2016 rental rate (Canada Mortgage and Housing Corporation, 2016). This resulted in a large gap between the cost of homeownership and rental. Rising costs of home ownership and increased difficulty for individuals to be approved for mortgages due to the increased rates encouraged them to shift towards the rental market for accommodation in 2018. As a result the vacancy rate of rental tenure across the GTA in 2018 is a low of 1.2 per cent, at an average rent of $\$ 1,359$. In comparison, the average vacancy rate in the City of Toronto in 2017 was estimated to be 1.1 per cent, which is the lowest recorded rate in the last 16 years and the average rent has increased by 4.5 per cent in 2017 in comparison to 3.1 per cent in 2016 (Canada Mortgage and Housing Corporation, 2017).

In 2015, the City of Toronto recorded to have more than half of Toronto's households rent, yet no new purpose rental housing is being built (City of Toronto, 2006). Since there is an increase in the demand and low supply of affordable rental housing, landlords charged new tenants significantly higher rents, averaging to be above 1.8 per cent in 2018 an increase of 0.3 per cent from 2017, which is above the provincial guideline. In 2018, CMHC recorded the vacancy rates for apartment units by bedroom type to be 1.6 per cent for bachelor units, 1.2 per cent for one Bedroom units, 1.0 per cent for two Bedroom units, and a low of 0.8 per cent for three Bedroom units. Secondary condominium suits were also recorded at a low 0.7 per cent vacancy rate (Canada Mortgage and Housing Corporation, 2019). 
As the pressure grew on demand within the City of Toronto for rental units, the average rents that were being charged for vacant units were approximately 18 per cent higher than those occupied. This also was translated in the decrease of unit turnover rate from 14.5 per cent in 2017 to 11.2 per cent in 2018 (Canada Mortgage and Housing Corporation, 2017). A Rental Market study conducted in 2018 by the City of Toronto showed that the asking rents were nearly 1.5 times above CMHC Average Market Rental Rate (AMR) and that the current affordable housing based on the set AMR was in shared accommodation. Table 1 demonstrates the average asking rents compared to average prevailing rents recorded in September 2017 based on a random sample of 4,895 cases.

Table 1: Toronto Average Asking Rents Compared to Average Prevailing Rents Rported by the City of Toronto Random Sample Data, September 2017

Sources: 2018 Rental Housing Market Conditions in Toronto

\begin{tabular}{|l|c|c|c|}
\hline \multicolumn{1}{|c|}{ Unit Type } & $\begin{array}{c}\text { A } \\
\text { CMHC Average } \\
\text { Monthly Rent }\end{array}$ & $\begin{array}{c}\text { Average Asking } \\
\text { Monthly Rent (\$) }\end{array}$ & $\begin{array}{c}\text { Difference CMHC and } \\
\text { Asking Rent }\end{array}$ \\
\hline Shared & NA & $\$ 735$ & NA \\
\hline Bachelor & $\$ 962$ & $\$ 1,342$ & 40 \\
\hline 1 Bedroom & $\$ 1,137$ & $\$ 1,614$ & $42 \%$ \\
\hline 2 Bedroom & $\$ 1,341$ & $\$ 2,252$ & $68 \%$ \\
\hline 3 Bedroom + & $\$ 1,595$ & $\$ 2,403$ & $50 \%$ \\
\hline All Units & $\$ 1,308$ & $\$ 1,829$ & $40 \%$ \\
\hline
\end{tabular}

In terms of demographic language, the largest age cohort that saw the strongest year over year growth within the rental market in almost two decades, are individuals aged 25-44 years old. Hence a large majority of the millennial population has shifted towards the rental market for tenure due to housing affordability issue within the City. The increase pressure of demand has helped push developers in the supply sector to build more rental units. In 2018 the average GTA stock increase of 3 per cent, which is equivalent to 17,000 condominium units, a 2 per cent decrease from the 19,000 units that were built in 2017. Most of the new rental housing within the City of Toronto was in the form of condominium rentals. Figure 10 demonstrates the number of residential units approved and built in Toronto from 2012 to 2016. Thus lack of supply and increased demand has only worked in favour of increasing rental rates across the region (Canada Mortgage and Housing Corporation, 2017). 
Figure 10: Number of Residential Units Approved and Built in Toronto from 2012 to 2016 Sources: 2018 Rental Housing Market Conditions in Toronto

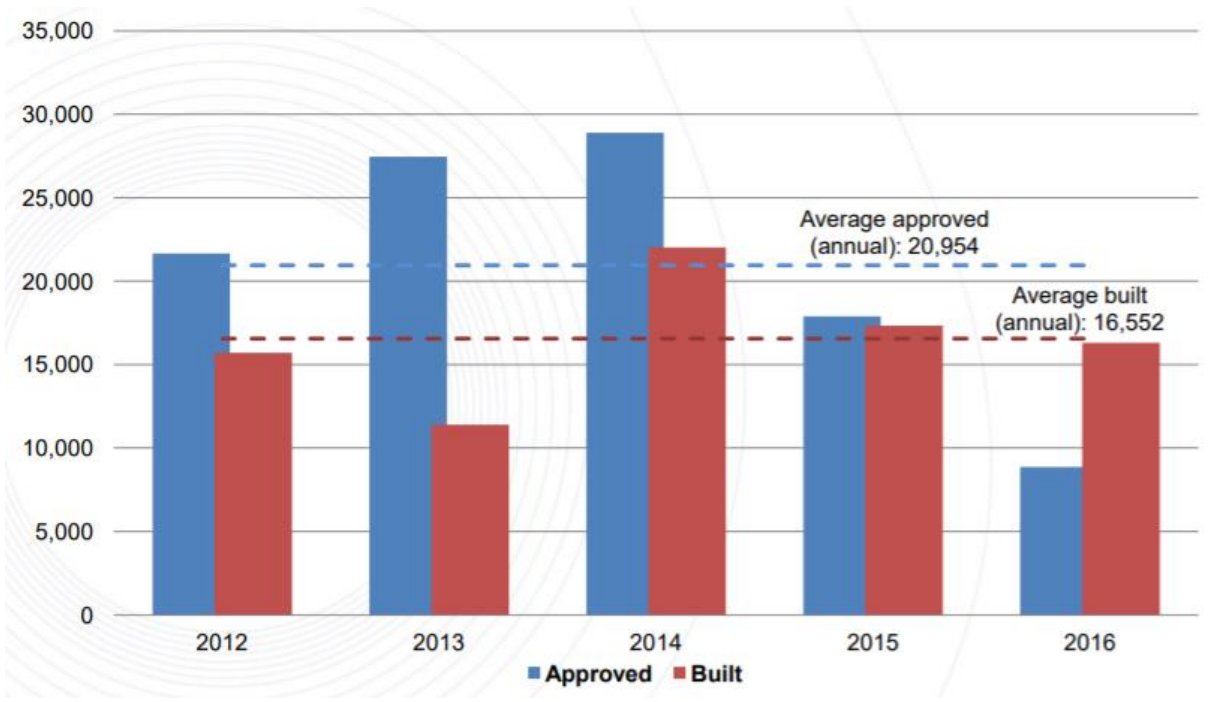

\section{INCOME}

One of the major factors contributing to decision of housing affordability is income. On a national level the average home price has increased by 67 per cent, while the household income has only increased by 13 per cent in the same time period (Pomeroy, 2012). According to the 2016 census, in 2015 the median household income across Canada was recorded as $\$ 70,366$ and $\$$ 74,287 in Ontario. In comparison the City of Toronto's median household income was the lowest in the Greater Toronto and Hamilton Area (GTHA) region at $\$ 65,829$.

Consequently, the median total income of individuals age 15 and older in Toronto was $\$ 30,089$. The total median income of individuals age 16 to 24 within the City of Toronto was recorded in 2015 at $\$ 11,500$ with an average of $\$ 16,700$ and ages 25 to 35 at $\$ 35,000$ with an average of $\$ 44,700$. This is the lowest of all regions in the GTHA. Within the City of Toronto, the highest median income can be found in the City Centre and around areas such as those bound by Bathurst Street, Leslie avenue, Wilson Avenue and Bathurst Street and Royal York Road and Bloor Street West (City of Toronto, 2017a). Figure 11 demonstrates the median household incomes recorded in 2015 in the City of Toronto. 
Figure 11: City of Toronto Median Household Income 2015 Sources: 2016 Census: Income Report

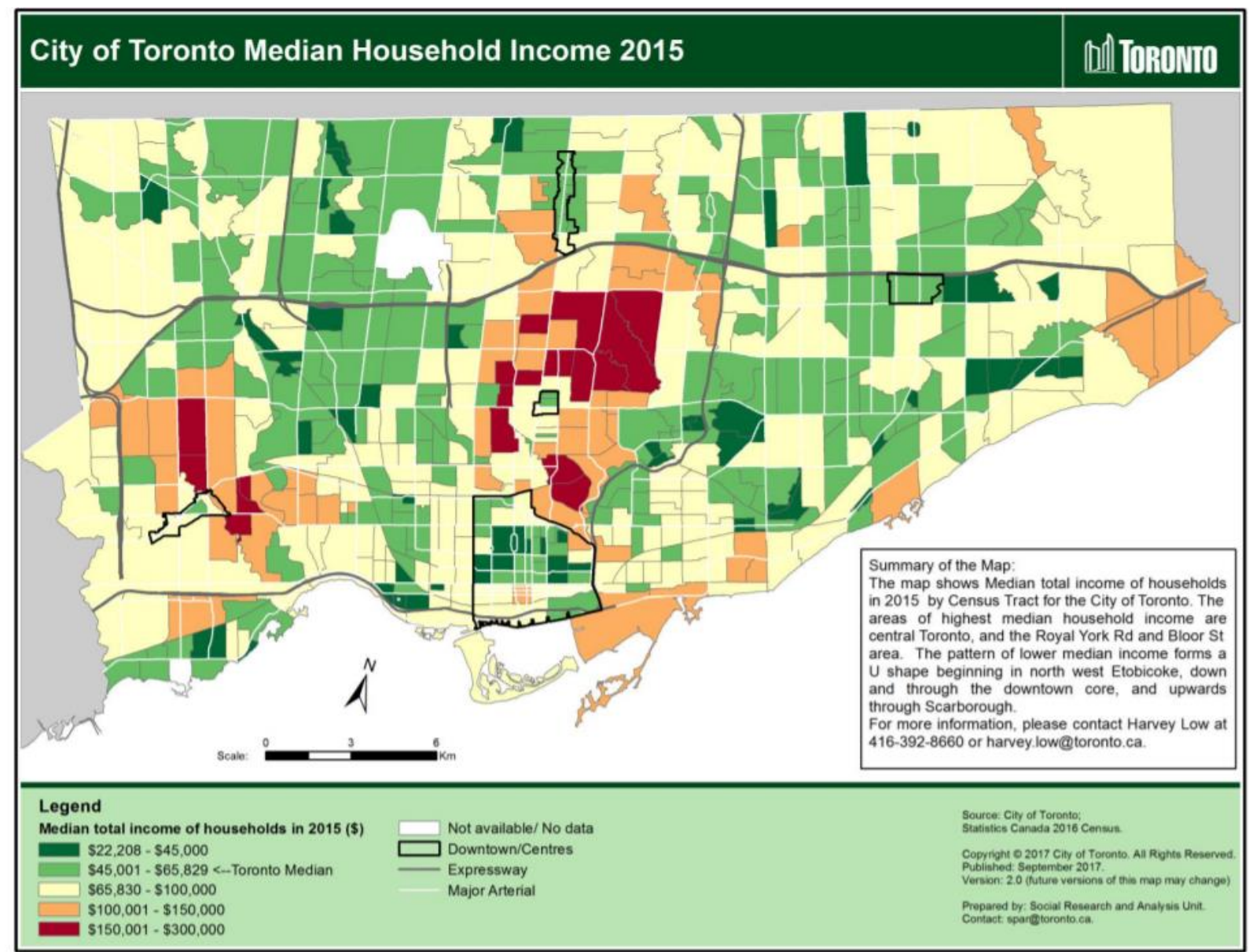

The median economic family income in Canada was recorded in 2015 at $\$ 88,306$, while across the province of Ontario the median was $\$ 91,089$. In comparison in the City of Toronto the income was $\$ 82,859$, the lowest within the GTHA regions. The City of Toronto also had 534,390 persons, which is 20.2 per cent of the population with an income below Statistics Canada's Low Income Measure After Tax (LIM-AT). LIM-AT is a relative measure of low income and not cost of living. In Toronto in 2015, adults between the age of 18 to 24 years old were recorded to be the highest prevailing group of low income at 27 per cent. This is the highest recorded rate of low income across Canada at 14.2 per cent, Ontario at 14.4 per cent, and GTHA at 11.9 per cent (City of Toronto, 2017a). 
During the 1960's when a large stock of rental housing was built, the income gap between owners and renters was approximately 20 per cent. However between 1984 and 1999 the gap between the median incomes of both tenures increased by 16 per cent, where in 1989 the median income of owners was almost double (198 per cent) and by 1999 (208 per cent) it has exceeded double the amount. Figure 13 demonstrates this increase is representative of an increase of almost 1 per cent a year in income gap. As such the wealth of homeowners was increased from 29 per cent to 70 per cent to that of renters (City of Toronto, 2017a). Also taking into consideration the inflation of the Canadian dollar value from 1984 to 2018 be at 113.04 per cent according to the Canadian Consumer Price Index (CPI), an average of 2.25 per cent per year (Official Data Foundation, 2019).

Figure 12: Comparison of Income and Wealth of Owner and Renter Households in Canada, 1984 and 1999 Sources: Statistics Canada, 1984 and 1999

\begin{tabular}{|c|c|c|c|c|c|}
\hline & \multicolumn{2}{|c|}{ Median income } & & \multicolumn{2}{|c|}{ Median net worth } \\
\hline & Owners & Renters & & Owners & Renters \\
\hline $1984^{1}$ & $\$ 41,380$ & $\$ 21,554$ & $1984^{1}$ & $\$ 116,845$ & $\$ 3,985$ \\
\hline 1999 & $\$ 43,478$ & $\$ 20,947$ & 1999 & $\$ 145,200$ & $\$ 2,060$ \\
\hline change & $\$ 2,098$ & $-\$ 607$ & change & $\$ 28,355$ & $-\$ 1,925$ \\
\hline$\%$ change & $5 \%$ & $-3 \%$ & $\%$ change & $24 \%$ & $-48 \%$ \\
\hline
\end{tabular}

By 2012, the average Canadian homeowner's net worth was approximately $\$ 824,000$ in comparison to $\$ 121,000$ in 1984 , an average of seven times increase over 28 years. Similarly rentals have increased from $\$ 16,000$ in 1984 to $\$ 120,000$ in 2012, an average of seven and half times increase. Thus making the gap between ownership and rentals increase from $\$ 105,000$ to $\$ 508,000$, an increase by 79 per cent (Christopher Pollon, 2017). 
Figure 13: Average Net Worth of Canadian Households by Tenure Between 1984 and 2012

Sources: CMHC. "Home Equity and Net Worth by Tenure and Age Group, Canada 1999, 2005 and 2012 (2012 constant dollars)"; 1984 numbers, CMHC, "Concentration of Wealth Through Ownership".

\section{Average net worth of Canadian households by tenure}

(rounded to the nearest $\$ 1 \mathrm{~K}$ )

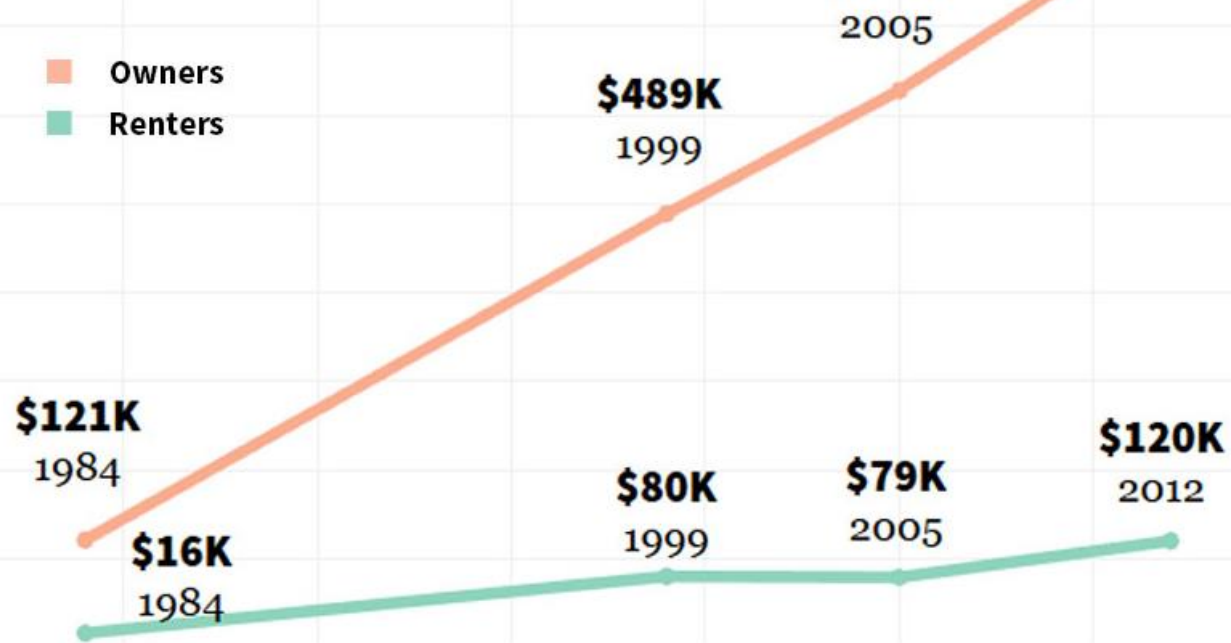

\section{ANALYSIS AND FINDINGS}

This section of the paper will analyze and address three major questions of what is affordable? For whom? And where is it located within the City of Toronto? Affordability will be explored using a number of methods and by dividing it into two types of tenure; Ownership and Rental. Before answering the first question it is important to note geographically what type of markets are millennials found to be residing in by overlaying census population data, 25 Ward boundaries and TREB market data. In terms of home ownership the following are the results:

\section{Detached House}

Figure 14 shows the average sale price of detached homes by submarket overlaid by Ward boundaries. The black dots on the map represent the millennial population density within each Ward. Ward 10 is predominantly yellow in colour with an average detached house is between $\$ 1,800,000$ and $\$ 2,100,000$. Ward 9 has a variety of three colours, ranging in sale price between $\$ 600,000$ and $\$ 2,100,000$. Ward13 is mostly blue at an 
average of $\$ 0.00$ and $\$ 300,000$ and Ward 18 is mostly light green at an average sale price between $\$ 1,200,000$ and $\$ 1,5000,000$.

Figure 14: Detached House Sale Price by Submarket, Ward and Millennial Population Sources: Author's Mapping using TREB Market Watch 2018, 25 Ward Open Data Boundary and Calculated Millennial Population using Ward profiles.
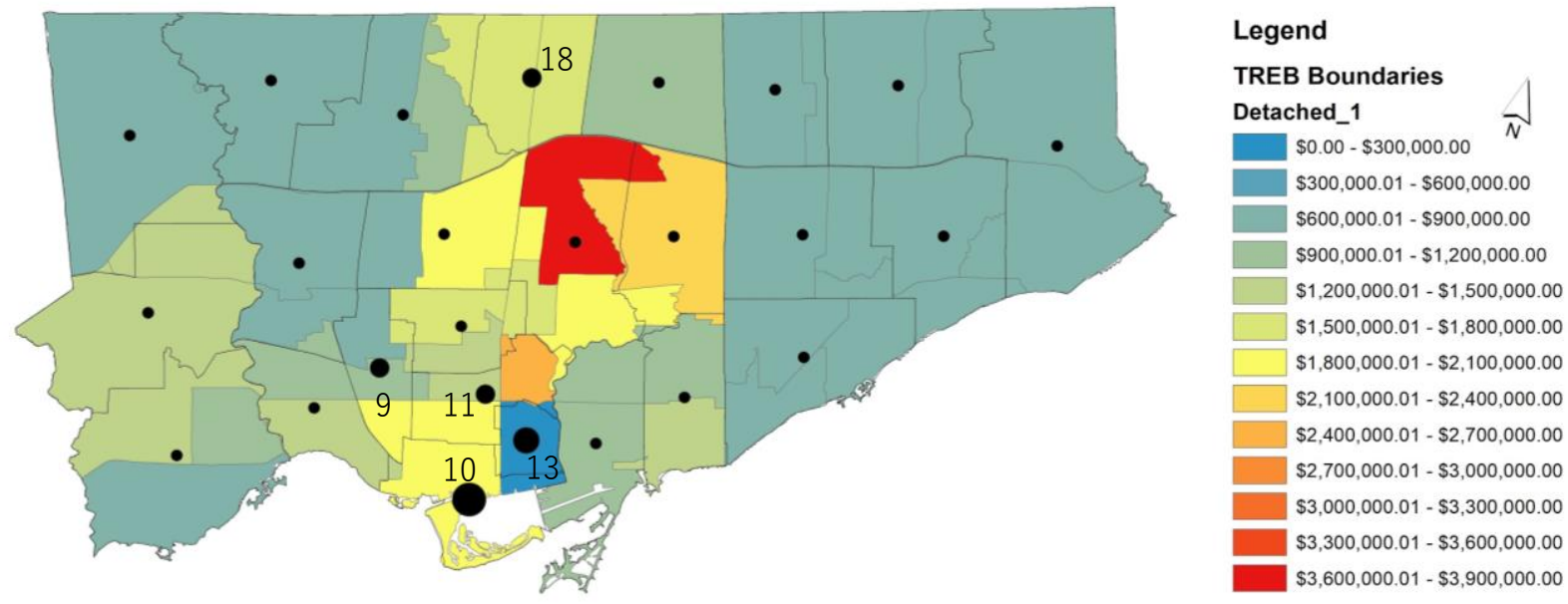

\section{Semi Detached}

Figure 15 shows the average sale price of semidetached homes by submarket overlaid by Ward boundaries. The black dots on the map represent the millennial population density within each Ward. Ward 10 shows to be predominantly yellow in colour with an average sale price between $\$ 1,200,000$ and $\$ 1,500,000$. Ward 9 has a variety of three colours, ranging in sale price between $\$ 600,000$ and $\$ 1,500,000$. Ward 13 is mostly orange at an average of $\$ 1,500,000$ and $\$ 1,800,000$ and Ward 18 is divided into two sections light green on the west and blue on the east at an average sale price between $\$ 0.0$ and $\$ 900,000$. 
Figure 15: Semi-detached House Sale Price by submarket, Ward and Millennial Population Sources: Author's Mapping using TREB Market Watch 2018, 25 Ward Open Data Boundary and Calculated Millennial Population using Ward profiles.
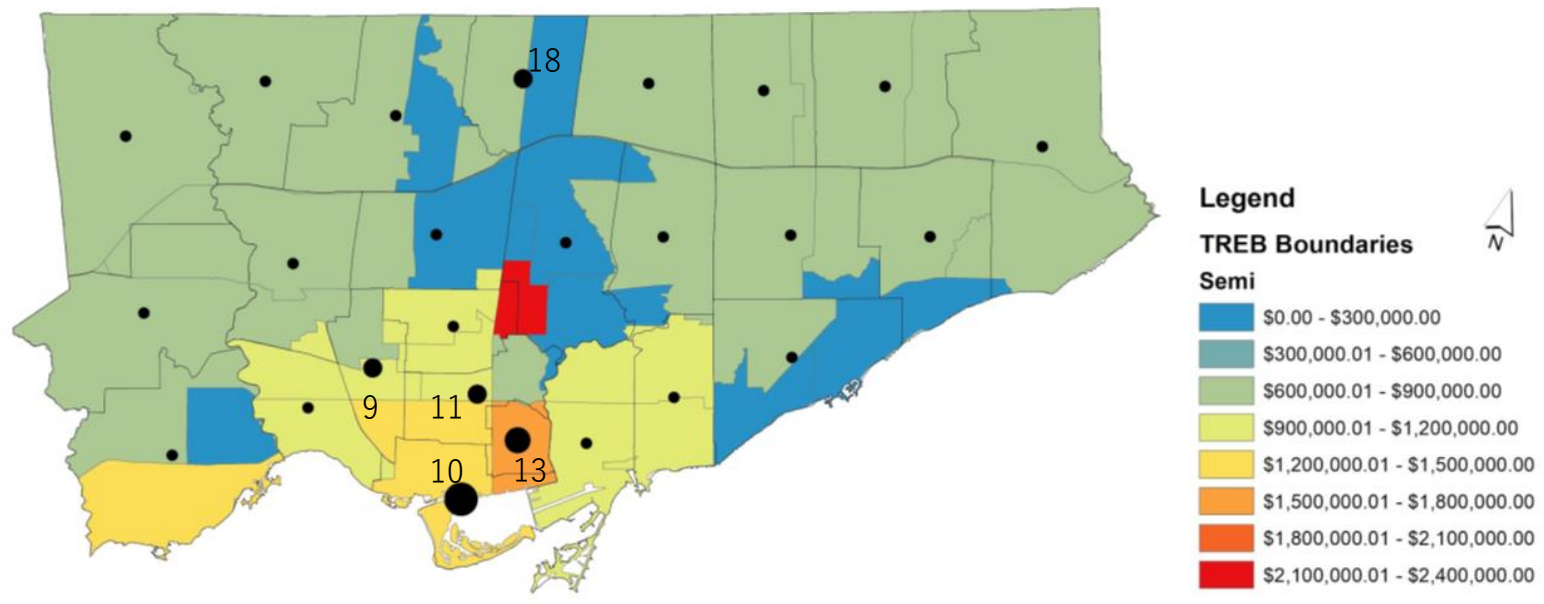

\section{Condominium Townhouse}

Figure 16 shows the average sale price of condominium townhouse by submarket overlaid by Ward boundaries. The black dots on the map represent the millennial population density within each Ward. Ward 10 shows to be predominantly red in colour with an average condo townhouse sale price between $\$ 900,000$ and $\$ 1,200,000$. Ward 9 is split into two colours - red on the south end and orange in the north, ranging in sale price between $\$ 600,000$ and $\$ 900,000$. Ward 13 is mostly orange at an average of $\$ 600,000-\$ 900,000$ and Ward 18 is divided into two sections light green on the west and orange on the east at an average sale price between $\$ 300,000$ and $\$ 900,000$. 
Figure 16: Condominium Townhouse Sale Price by Submarket, Ward and Millennial Population Sources: Author's Mapping using TREB Market Watch 2018, 25 Ward Open Data Boundary and Calculated Millennial Population using Ward profiles.

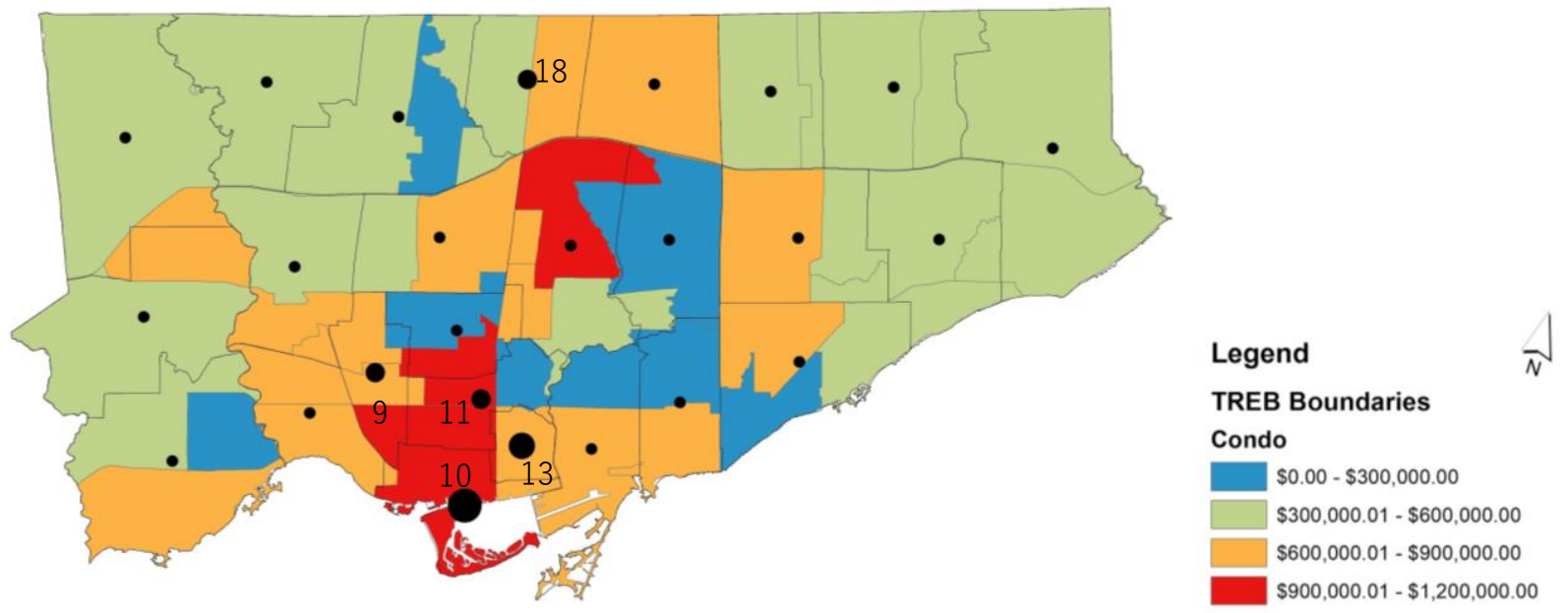

\section{Condominium Apartment}

Figure 17 shows the average sale price of condominium apartment by submarket overlaid by Ward boundaries. The black dots on the map represent the millennial population density within each Ward. Ward 10 is predominantly light green in colour with an average condo apartment between $\$ 600,000$ and $\$ 900,000$. Ward 9 is split into two colours - light and dark green, ranging in sale price between $\$ 300,000$ and $\$ 900,000$. Ward 13 is also split in three colours light green, orange and yellow at an average of $\$ 600,000$ and $\$ 1,500,000$ and Ward 18 is covered in light green at an average sale price between $\$ 600,000$ and $\$ 900,000$.

Figure 17: Condo Apartments Sale Price by Submarket, Ward and Millennial Population Sources: Author's Mapping using TREB Market Watch 2018, 25 Ward Open Data Boundary and Calculated Millennial Population using Ward profiles.
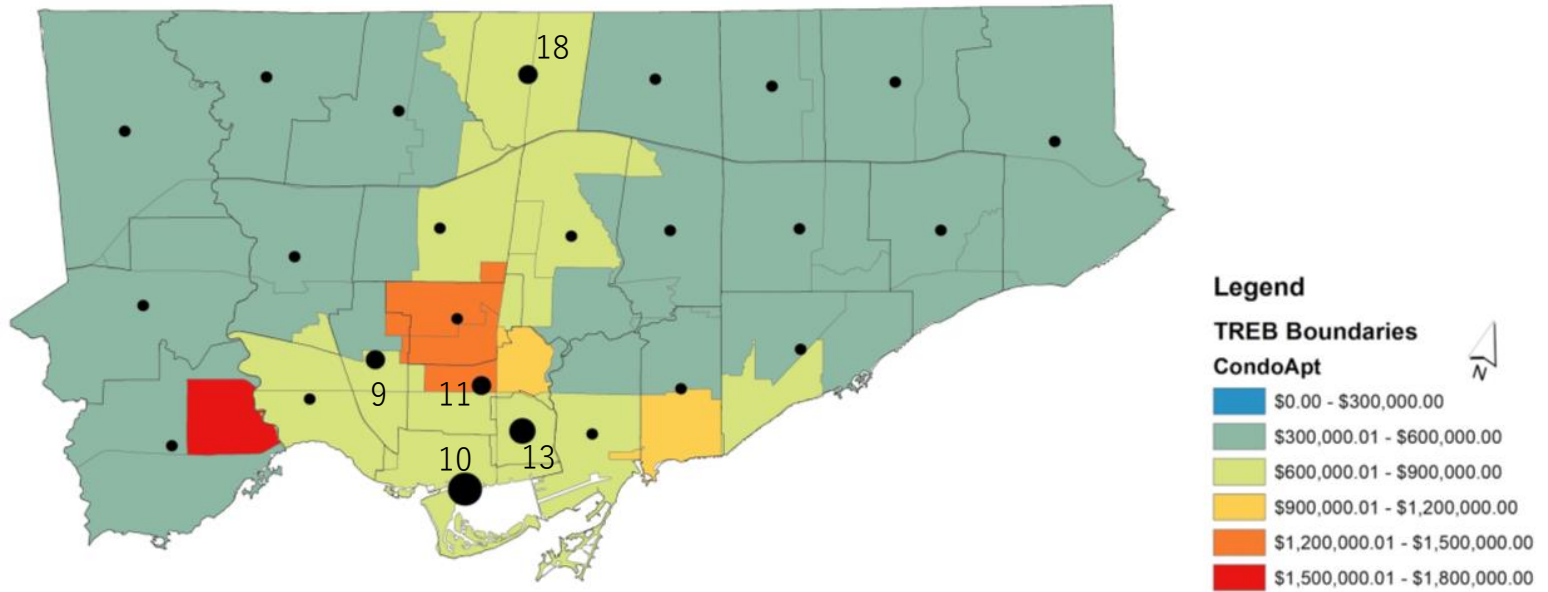


\section{Row/Townhouse}

Figure 18 shows the average sale price of a row townhouse by submarket overlaid by Ward boundaries. The black dots on the map represent the millennial population density within each Ward. Ward 10 is predominantly red in colour with an average row townhouse between $\$ 1,200,000$ and $\$ 1,500,000$. Ward 9 is split into three colours - red on the south, yellow in the centre and blue in the north, ranging in sale price between $\$ 0$ and $\$ 1,200,000$. Ward 13 is mostly red at an average of $\$ 1,200,000$ and $\$ 1,500,000$ and Ward 18 is divided into two sections blue on the west side and red on the east side at an average sale price between $\$ 0$ and $\$ 1,500,000$.

\section{Figure 18: Row Townhouse Sale Price by Submarket, Ward and Millennial Population Sources: Author's Mapping using TREB Market Watch 2018, 25 Ward Open Data Boundary and Calculated Millennial Population using Ward profiles.}

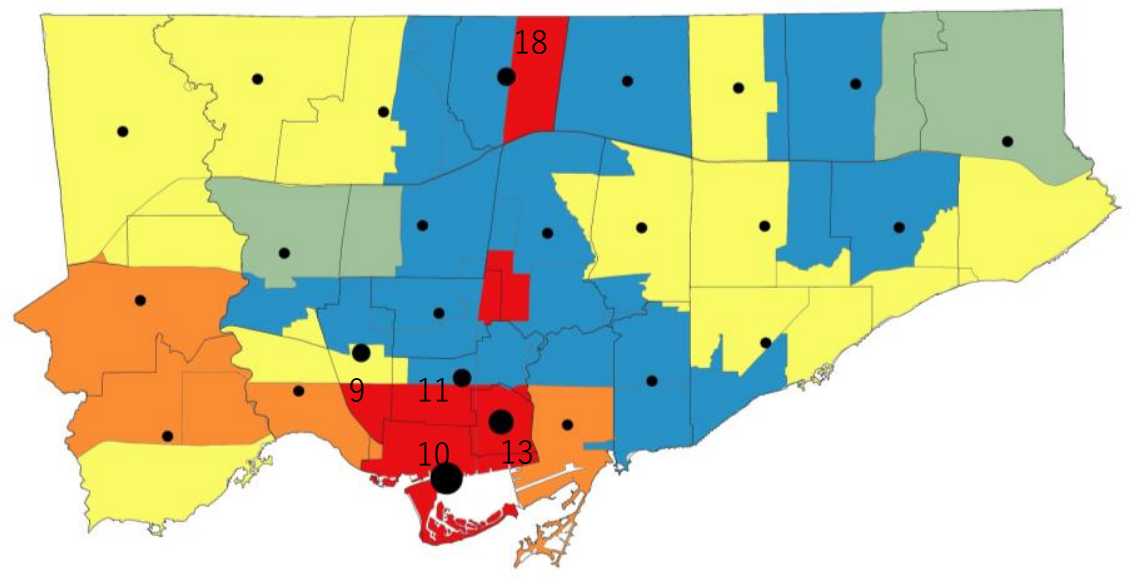

\section{Co-apartment}

Figure 19 shows the average sale price of co-apartment by submarket overlaid by Ward boundaries. The black dots on the map represent the millennial population density within each Ward. All the Wards are coloured in blue with a price range between $\$ 0$ and $\$ 100,000$. 
Figure 19: Co-apartment Sale Price by Submarket, Ward and Millennial Population Sources: Author's Mapping using TREB Market Watch 2018, 25 Ward Open Data Boundary and Calculated Millennial Population using Ward profiles.
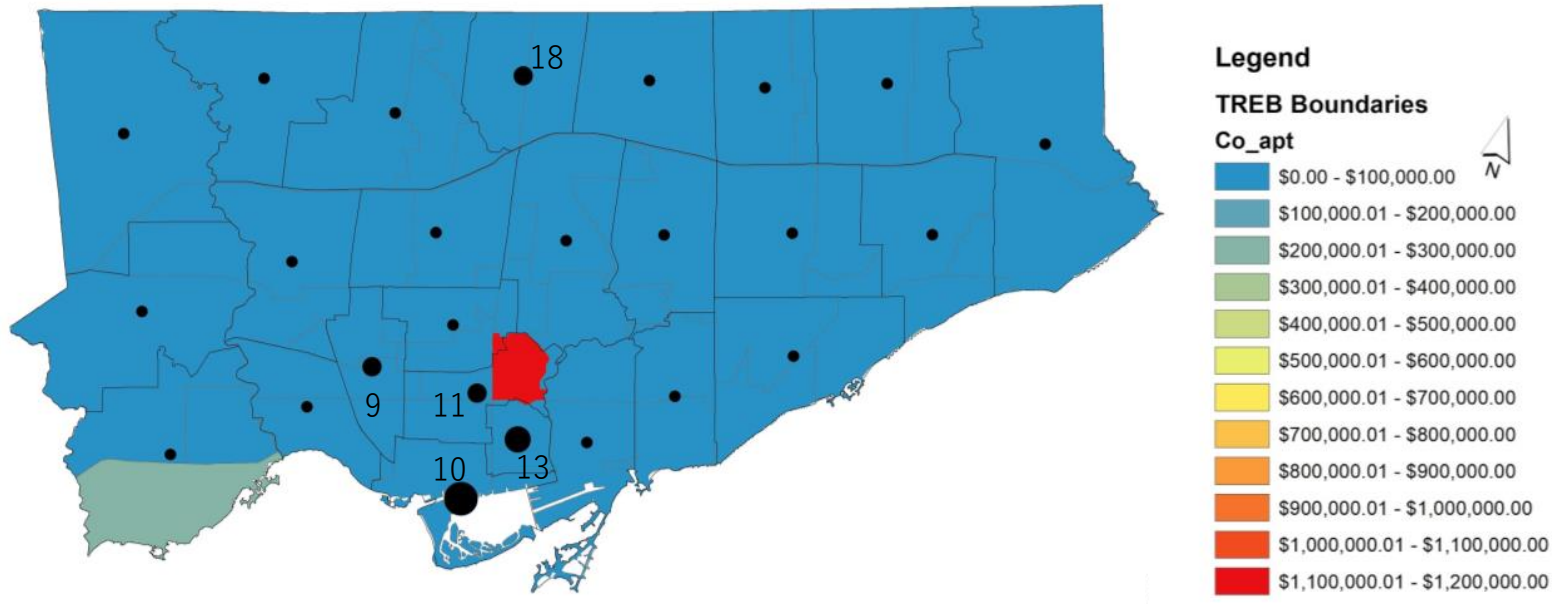

\section{Co-ownership apartment}

Figure 20 shows the average sale price of co-ownership apartment by submarket overlaid by Ward boundaries. The black dots on the map represent the millennial population density within each Ward. All the Wards are coloured in blue with a price range between $\$ 0$ and $\$ 100,000$, except Ward 13 which is coloured in light green with a purchase price average between $\$ 300,000$ and $\$ 400,000$.

Figure 20: Co-ownership apartment Sale Price by Submarket, Ward and Millennial Population Sources: Author's Mapping using TREB Market Watch 2018, 25 Ward Open Data Boundary and Calculated Millennial Population using Ward profiles
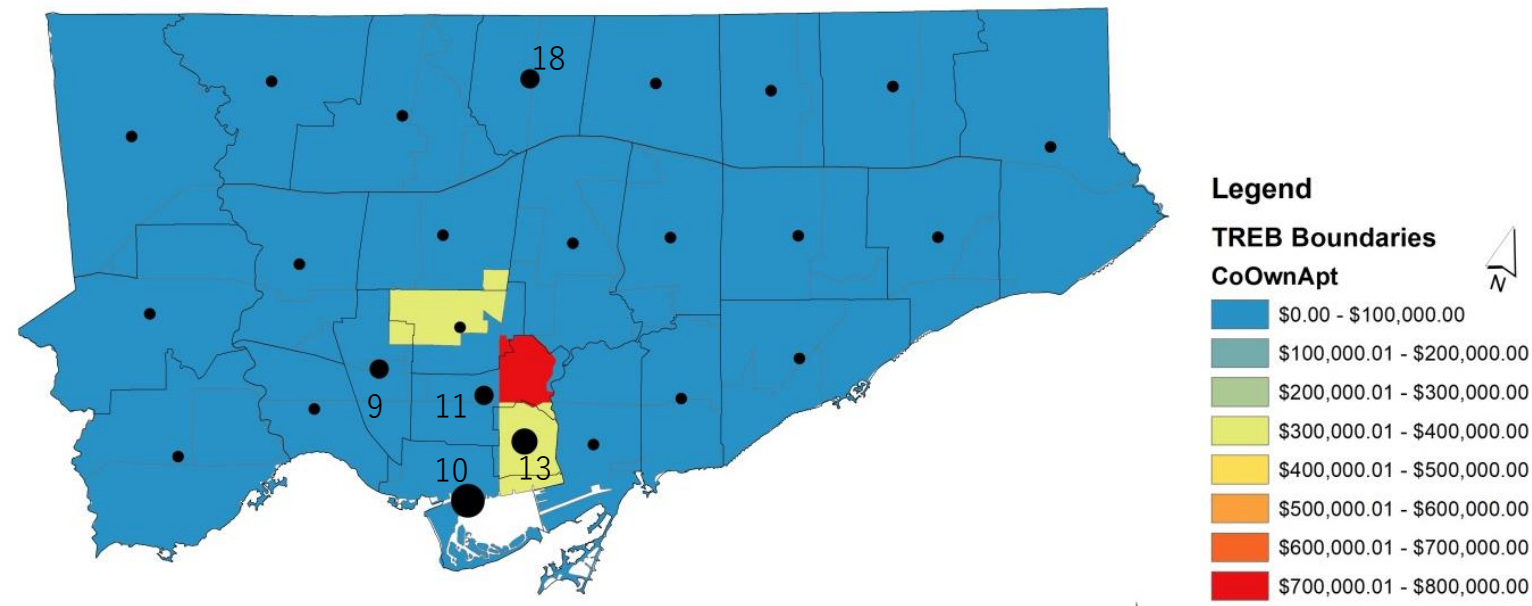


\subsection{AFFORDABILITY ANALYSIS CITY WIDE}

In order to determine affordability by ownership tenure, the ratio method is used. Income deciles are used as the premise from which affordability is calculated as a ratio of income. According to CMHC, income deciles are used to "take into account economies of scale present in larger households, the different types of income are adjusted by dividing the household income by the square root of the household size. All persons in the population are ranked from lowest to highest by the value of their adjusted household income. Then, the ranked population is divided into ten groups of equal numbers of units, called deciles"(Statistics Canada, 2017). Using CMHC's income ratio method, 30 per cent of the income decile was used to determine the amount that households can afford to pay their mortgages without being in financial distress. Following that, the stress test method was applied by using a the calculation of a10 per cent down payment, 5.34 per cent interest rate and a 25 year amortization period. Table 2 shows that based on these assumptions by the $9^{\text {th }}$ decile the maximum affordable mortgage is $\$ 370,800$.

Table 2: Affordable Mortgage Based on After Tax Income Decile 2017

Sources: Author's calculation of affordable mortgage using Stats Canada adjusted after tax income 2017, CMHC affordability ration of $30 \%$ of income, and stress test qualifications (10\% down payment, $5.34 \%$ interest rate over 25 year amortization period).

\begin{tabular}{|l|c|c|c|}
\hline Income Decile & 2017 constant dollars & $30 \%$ of Income & Affordable Mortgage \\
\hline Decile 1 & $\$ 14,200$ & $\$ 4,260$ & $\$ 63,600$ \\
\hline Decile 2 & $\$ 24,800$ & $\$ 7,440$ & $\$ 111,200$ \\
\hline Decile 3 & $\$ 31,500$ & $\$ 9,450$ & $\$ 141,100$ \\
\hline Decile 4 & $\$ 38,200$ & $\$ 11,460$ & $\$ 171,200$ \\
\hline Decile 5 & $\$ 44,900$ & $\$ 13,470$ & $\$ 201,300$ \\
\hline Decile 6 & $\$ 51,900$ & $\$ 15,570$ & $\$ 232,800$ \\
\hline Decile 7 & $\$ 59,500$ & $\$ 17,850$ & $\$ 266,800$ \\
\hline Decile 8 & $\$ 69,100$ & $\$ 20,730$ & $\$ 309,800$ \\
\hline Decile 9 & $\$ 82,700$ & $\$ 24,810$ & $\$ 370,800$ \\
\hline Decile 10 & $\$ 132,900$ & $\$ 39,870$ & $\$ 595,800$ \\
\hline
\end{tabular}

Figure 21 shows that based on the average sales price by tenure as reported by TREB 2018 report. The results demonstrate that at the average price only individuals earning an income above the 9th decile at a minimum of $\$ 105,240$ to be able to afford the cheapest option of Coownership apartment at $\$ 471,667$. According to data from Statistics Canada, the average millenial age 20-34 has an income of $\$ 44,700$. This means that the maximum mortgage price 
that the average millennial within this age cohort can afford using this method is $\$ 200,400$, a gap of $\$ 271,267$.

Figure 21: Affordable Mortgage Based on After Tax Income Decile 2017 and Average Market Sale Price by Housing Typology (Red)

Sources: Author's calculation of affordable mortgage using Stats Canada adjusted after tax income 2017, CMHC affordability ration of $30 \%$ of income, and stress test qualifications ( $10 \%$ down payment, $5.34 \%$ interest rate over 25 year amortization period), TREB average price by housing typology, Statistics Canada average millennial income in the City of Toronto.

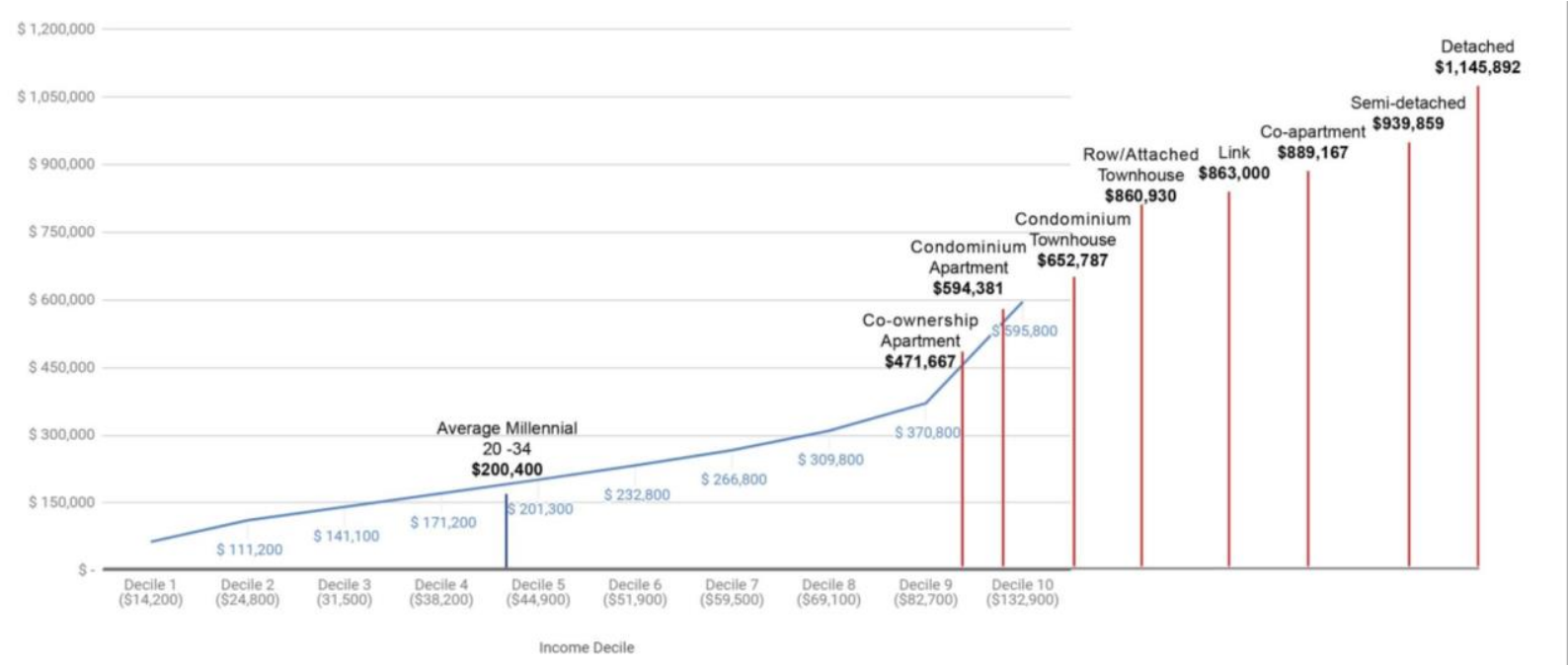

As for rental, based on 30 per cent of income, $\$ 1,118$ will be the maximum affordable rental price per month for the average millennial between the age of 20 and 34 . Figure 22 demonstrates the average market rates by typology and the average millennial affordable rent payment. The maximum affordable rental price for the average millennial is much lower than the minimum average rent of a bachelor unit in a townhouse at $\$ 1,583$ according to TREB Q4 2018 report (Toronto Region Board of Trade, 2018). This is a difference of $\$ 465$ per month, thus setting minimum income to afford the townhouse bachelor unit at $\$ 63,320$. Table 3 shows the maximum affordable price per month based on 30 per cent ration of income by decile.

Table 3: Affordable Monthly Rent Payment Based on After Tax Income Decile 2017

Sources: Author's calculation of affordable mortgage using Stats Canada adjusted after tax income 2017, CMHC affordability ration of $30 \%$ of income divided by 12 for maximum monthly payment.

\begin{tabular}{|l|c|c|c|}
\hline Income Decile & 2017 constant dollars & $30 \%$ of income & 30\% of income per month \\
\hline Decile 1 & $\$ 14,200$ & $\$ 4,260$ & $\$ 355.00$ \\
\hline Decile 2 & $\$ 24,800$ & $\$ 7,440$ & $\$ 620.00$ \\
\hline Decile 3 & $\$ 31,500$ & $\$ 9,450$ & $\$ 787.50$ \\
\hline Decile 4 & $\$ 38,200$ & $\$ 11,460$ & $\$ 955.00$ \\
\hline Decile 5 & $\$ 44,900$ & $\$ 13,470$ & $\$ 1,122.50$ \\
\hline
\end{tabular}




\begin{tabular}{|l|c|c|c|}
\hline Decile 6 & $\$ 51,900$ & $\$ 15,570$ & $\$ 1,297.50$ \\
\hline Decile 7 & $\$ 59,500$ & $\$ 17,850$ & $\$ 1,487.50$ \\
\hline Decile 8 & $\$ 69,100$ & $\$ 20,730$ & $\$ 1,727.50$ \\
\hline Decile 9 & $\$ 82,700$ & $\$ 24,810$ & $\$ 2,067.50$ \\
\hline Decile 10 & $\$ 132,900$ & $\$ 39,870$ & $\$ 3,322.50$ \\
\hline
\end{tabular}

Figure 22: Affordable Monthly Rent Based on After Tax Income Decile 2017 and Average Market Rental Price for Apartment (Red) and Townhouse (Green)

Sources: Author's calculation of affordable mortgage using Stats Canada adjusted after tax income 2017, CMHC affordability ration of $30 \%$ of income divided by $\mathbf{1 2}$ for maximum monthly payment, TREB average price by housing typology, Statistics Canada average millennial income in the City of Toronto.

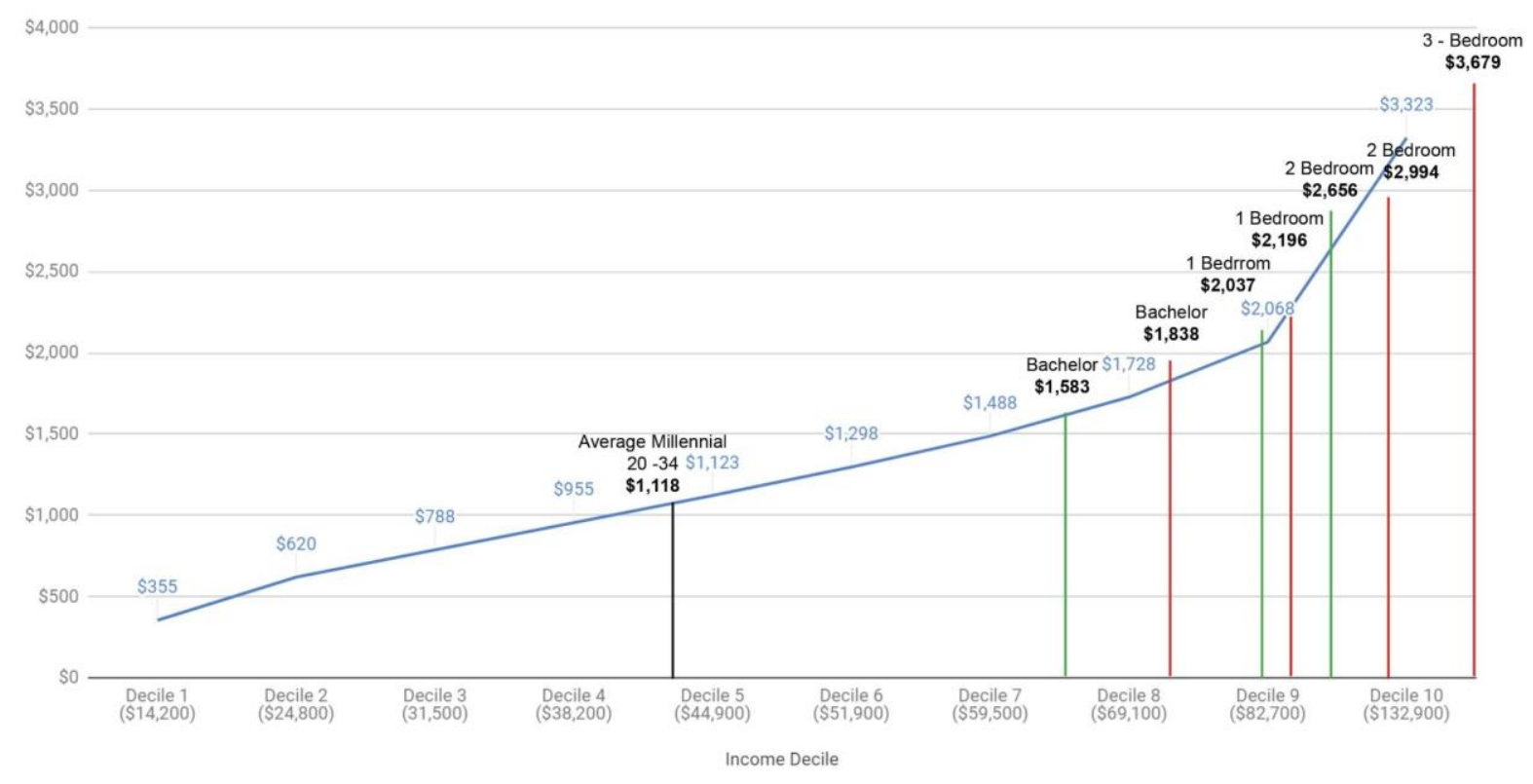

On a local level applying the City of Toronto's definition and method to calculate affordability of housing by ownership tenure, the house must be priced "at or below an amount where the total monthly shelter cost (mortgage principal and interest - based on a 25-year amortization, 10 percent down payment and the chartered bank administered mortgage rate for a conventional 5year mortgage as reported by the Bank of Canada at the time of application - plus property taxes calculated on a monthly basis) equals the average City of Toronto rent, by unit type, as reported annually by the Canada Mortgage and Housing Corporation. Affordable ownership price includes GST and any other mandatory costs associated with purchasing the unit" (City of Toronto, 2006). So to analyze affordability according to this definition a 10 per cent down 
payment is assumed, with a 5.34 per cent mortgage interest rate on a 25 year amortization period. Property taxes are typically calculated tax rate of 0.6355054 per cent of the property value based on 2018 City tax rate of 0.463239 per cent, 2018 Education tax rate of 0.1700000 per cent and 2018 City Building Fund rate of 0.0022685 per cent (City of Toronto, 2019c). However for the purposes of this analysis, property tax is assumed to be constant at an average of $\$ 100$ per month for all tenure types. Table 4 shows the maximum affordable house price based on these assumptions.

Table 4: Affordable Monthly Rent and Mortgage Payment Based Greater Toronto Area AMR 2019 Sources: Author's calculation of affordable mortgage using 2019 AMR, assuming \$100 payment in property taxes, $10 \%$ down payment, $5.34 \%$ interest rate amortized over 25 years.

\begin{tabular}{|c|c|c|c|c|}
\hline Unit Size & $\begin{array}{c}2019 \\
\text { Average Market Rent }\end{array}$ & $\begin{array}{c}\text { Max. Mortgage / } \\
\text { House price }\end{array}$ & Property Tax & Rent per month \\
\hline Bachelor apartment & $\$ 1,089$ & $\$ 177,300$ & $\$ 100$ & $\$ 989$ \\
\hline 1 Bedroom apartment & $\$ 1,270$ & $\$ 209,800$ & $\$ 100$ & $\$ 1,170$ \\
\hline 2 Bedroom apartment & $\$ 1,492$ & $\$ 249,600$ & $\$ 100$ & $\$ 1,392$ \\
\hline 3 Bedroom apartment & $\$ 1,664$ & $\$ 280,400$ & $\$ 100$ & $\$ 1,564$ \\
\hline 4 Bedroom apartment & $\$ 1,954$ & $\$ 332,400$ & $\$ 100$ & $\$ 1,854$ \\
\hline 5 Bedroom apartment & $\$ 2,185$ & $\$ 373,800$ & $\$ 100$ & $\$ 2,085$ \\
\hline 2 Bedroom townhouse & $\$ 1,660$ & $\$ 279,600$ & $\$ 100$ & $\$ 1,560$ \\
\hline 3 Bedroom townhouse & $\$ 1,731$ & $\$ 292,400$ & $\$ 100$ & $\$ 1,631$ \\
\hline 4 Bedroom townhouse & $\$ 2,203$ & $\$ 377,100$ & $\$ 100$ & $\$ 2,103$ \\
\hline 5 Bedroom townhouse & $\$ 2,548$ & $\$ 438,900$ & $\$ 100$ & $\$ 2,448$ \\
\hline
\end{tabular}

Assuming that property taxes are part of the equation that makes up for the maximum affordable monthly shelter cost, it further reduces the mortgage payments that households can afford per month. Thus leading to even lower maximum house price than the total payment allocated based on 30 of income. In comparing the average affordable apartment price based on the above table at $\$ 270,500$ in comparison to the average market price of $\$ 594,381$, there is a difference of $\$ 323,881$, a 55 per cent increase. Also considering the average millennial 20 to 34 years of age only earns an average of $\$ 44,700$, affording a maximum mortgage of $\$ 200,400$ calculated based on 30 per cent of income, the only available option that would be affordable is the bachelor apartment. Assuming that AMR is representative of 30 per cent of income, it can then be assumed that the minimum income rates that are considered to qualify for affordability can be calculated at a $100 \%$ as shown in Table 5 . 
Table 5: Income limit rates based on Greater Toronto Area AMR 2019

Sources: Author's calculation of income using 2019 City of Toronto AMR, assuming AMR is $30 \%$ of Income.

\begin{tabular}{|l|c|c|}
\hline Unit Size & $\begin{array}{c}\text { 2019 City of Toronto } \\
\text { Average Market Rent }\end{array}$ & Minimum Income \\
\hline Bachelor apartment & $\$ 1,089$ & $\$ 43,560$ \\
\hline 1 Bedroom apartment & $\$ 1,270$ & $\$ 50,800$ \\
\hline 2 Bedroom apartment & $\$ 1,492$ & $\$ 59,680$ \\
\hline 3 Bedroom apartment & $\$ 1,664$ & $\$ 66,560$ \\
\hline 4 Bedroom apartment & $\$ 1,954$ & $\$ 78,160$ \\
\hline 5 Bedroom apartment & $\$ 2,185$ & $\$ 87,400$ \\
\hline 2 Bedroom townhouse & $\$ 1,660$ & $\$ 66,400$ \\
\hline 3 Bedroom townhouse & $\$ 1,731$ & $\$ 69,240$ \\
\hline 4 Bedroom townhouse & $\$ 2,203$ & $\$ 88,120$ \\
\hline 5 Bedroom townhouse & $\$ 2,548$ & $\$ 101,920$ \\
\hline
\end{tabular}

Comparing the affordable rent for apartments and townhouses per month to that of the prices asked by the market for bachelor, 1 Bedroom, 2 Bedrooms and 3 Bedrooms typology, a huge gap is visible. Figure 23 demonstrates this gap, which is on average a 50 per cent increase on the affordable rent per month.

Figure 23: Affordable Monthly Rent Based on 2019 AMR Versus Monthly Rent Based on Q4 TREB 2018. Sources: Greater Toronto Area AMR 2019 and Rental Market Report Q4 2018

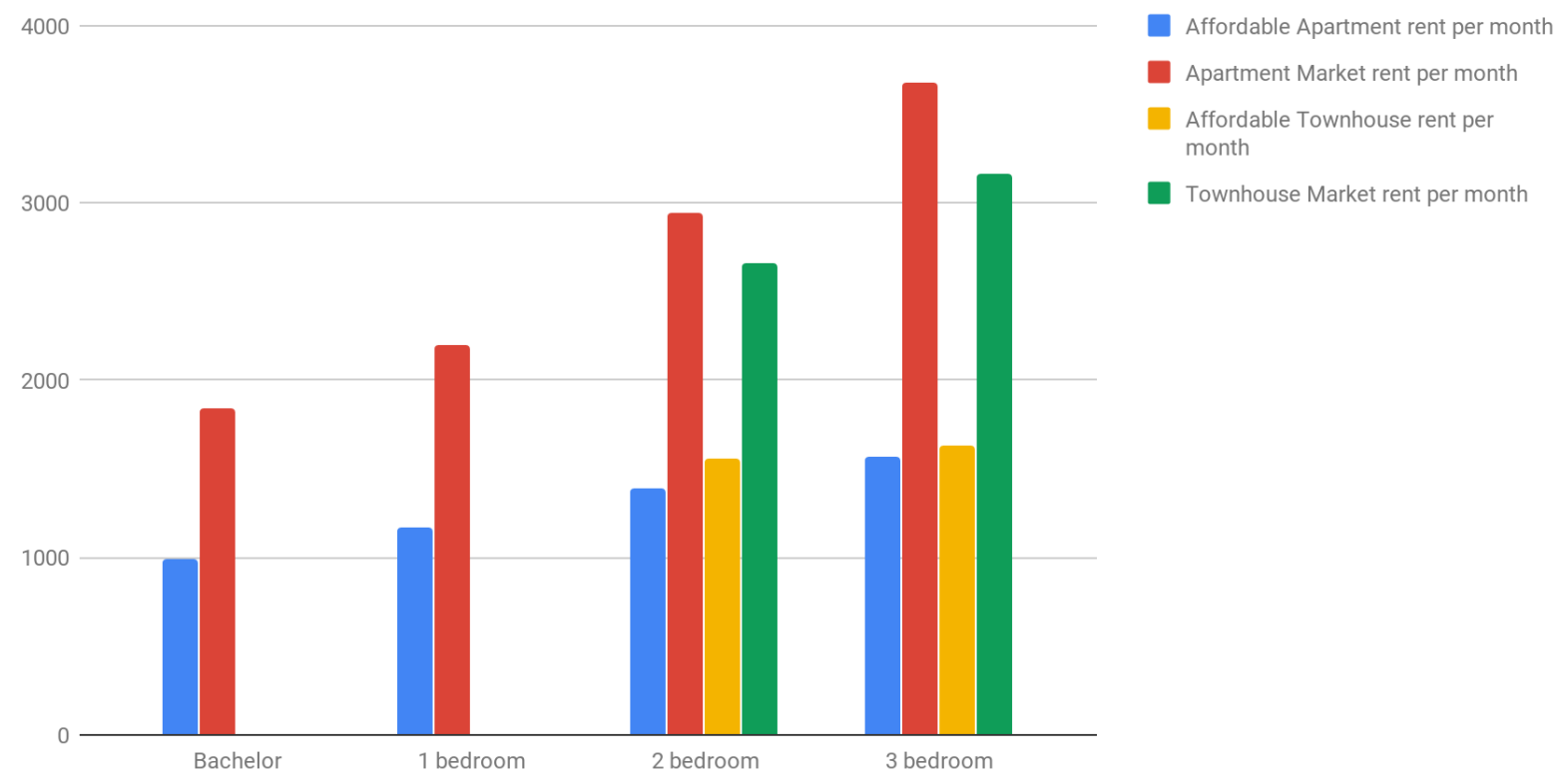


According to CMHC the Average Market Rents (AMR) for the GTA figures published in fall of 2018, used to guide and set the affordable monthly cost of rents in 2019. These numbers are used as base numbers to qualify for an affordable housing unit within the City of Toronto. To qualify, households must have an annual income less than the initial income limit, which is equal to four times the monthly occupancy cost for housing unit multiplied by 12 (City of Toronto, 2019a). Table 6 represents the Initial Income limits as calculated by this definition. Thus at an average annual income of $\$ 44,700$, the average millennial of 20 to 34 years of age is eligible for affordable housing rental units. This also means that up to 3 Bedroom range of either apartment or townhouse units, households earning between the 8th decile and the 9th decile are not eligible for affordable housing units and are forced to spend more than the affordable rate to find market rate housing.

Table 6: Initial Income Limit Rates Based on Greater Toronto Area AMR 2019 Sources: Author's calculation of initial income limits using City of Toronto definition and 2019 AMR

\begin{tabular}{|l|c|c|}
\hline Unit Size & $\begin{array}{c}\text { 2019 City of Toronto } \\
\text { Average Market Rent }\end{array}$ & Initial Income limit \\
\hline Bachelor apartment & $\$ 1,089$ & $\$ 52,272$ \\
\hline 1 Bedroom apartment & $\$ 1,270$ & $\$ 60,960$ \\
\hline 2 Bedroom apartment & $\$ 1,492$ & $\$ 71,616$ \\
\hline 3 Bedroom apartment & $\$ 1,664$ & $\$ 79,872$ \\
\hline 4 Bedroom apartment & $\$ 1,954$ & $\$ 93,792$ \\
\hline 5 Bedroom apartment & $\$ 2,185$ & $\$ 104,880$ \\
\hline 2 Bedroom townhouse & $\$ 1,660$ & $\$ 79,680$ \\
\hline 3 Bedroom townhouse & $\$ 1,731$ & $\$ 83,088$ \\
\hline 4 Bedroom townhouse & $\$ 2,203$ & $\$ 105,744$ \\
\hline 5 Bedroom townhouse & $\$ 2,548$ & $\$ 122,304$ \\
\hline
\end{tabular}

So in conclusion based on the current recorded average millennial income at $\$ 44,700$, theoretically market supply of housing that is affordable is only limited to bachelor units, otherwise are limited to affordable housing units. Practically based on market rates, bachelor units are at much higher rates than that of the affordable AMR, and thus leaving millennials with the average income to resort to affordable housing units. In terms of units supply within the City, the report shows that of 4,895 units that were listed to the market for rent in 2017only 34 per cent were below the affordable threshold, making it even harder for millennials to find housing (City of Toronto, 2018a). 
Table 7: Toronto Percentage of Units Below Affordable Threshold by Unit Type, 2017 Sources: 2018 Rental Housing Market Conditions in Toronto

\begin{tabular}{|c|c|c|c|c|}
\hline & A & B & C & D \\
\hline Unit Type & Listed Units & $\begin{array}{l}\text { Listed Units } \\
\text { Below Threshold }\end{array}$ & $\begin{array}{l}\text { Percent of Units } \\
\text { below Threshold }\end{array}$ & $\begin{array}{c}\text { Rent Threshold } \\
\text { Tested }\end{array}$ \\
\hline Shared & 1,585 & 1,166 & $74 \%$ & $\$ 800$ \\
\hline Bachelor & 287 & 61 & $21 \%$ & $\$ 962$ \\
\hline 1 Bedroom & 1,393 & 247 & $18 \%$ & $\$ 1,137$ \\
\hline 2 Bedroom & 1,351 & 157 & $12 \%$ & $\$ 1,341$ \\
\hline 3 Bedroom & 279 & 27 & $10 \%$ & $\$ 1,536$ \\
\hline All Units & 4,895 & 1,658 & $34 \%$ & \\
\hline
\end{tabular}

\subsection{MILLENNIAL AFFORDABILITY WITHIN WARDS 9,10,11,13 AND 18}

Interestingly millennials population concentration as discussed in the demographics section is located in Wards 9, 10,11, 13 and 18. Assuming that millennials within these Wards earn the average Ward income, the following methodology is used to analyze affordability within each of the Wards;

1. Ownership analysis - assuming 30 per cent affordability ratio of income, 10 percent down payment and $5.34 \%$ interest rate at a 25 -year amortization period.

2. Rental analysis - assuming 30 per cent ration of income divided by 12 to determine affordable monthly rent payment.

3. Income Ratio Analysis - analyzing affordability by tenure and typology of applicable submarkets at $30 \%, 50 \%$ and $70 \%$ of income.

4. Ward New Housing Supply Analysis - Based on CMHC New Construction 2018 information Portal by neighbourhood boundary. Lack of supply in the resale housing market may lead potential buyers to meet their housing needs through the new housing market. Reduced demand for existing homes results in excess supply even in the absence of new construction. Hence housing prices would be expected to experience downward pressures until excess supply is absorbed(Canadian Mortgage and Housing Corporation (CMHC), 2019). 


\subsubsection{WARD 9 - DAVENPORT}

Ward 9 is bound by the Canadian Pacific Rail (CP) tracks on the west and south. To the north are Rogers Road, Eglinton Avenue West and Dufferin Street. To the south are Winona Drive, Ossington Avenue, Dundas Street West and Davenport Road to the east. The ward is currently under the jurisdiction of Ana Bailao, the elected councillor. Layering Ward 9 boundary on top of the TREB submarket boundaries, submakets C08, W02, W03 a small portion of C02 highlighted with a black outline on are their boundaries on Figure 24 and in Appendix A and B. These submarkets make up the relative markets to which affordability within the Ward should be compared.

Figure 24: Ward 9 Profile with Overlaid TREB Submarket Boundary Sources: City of Toronto Ward 9 Profile and TREB Submarket Boundaries

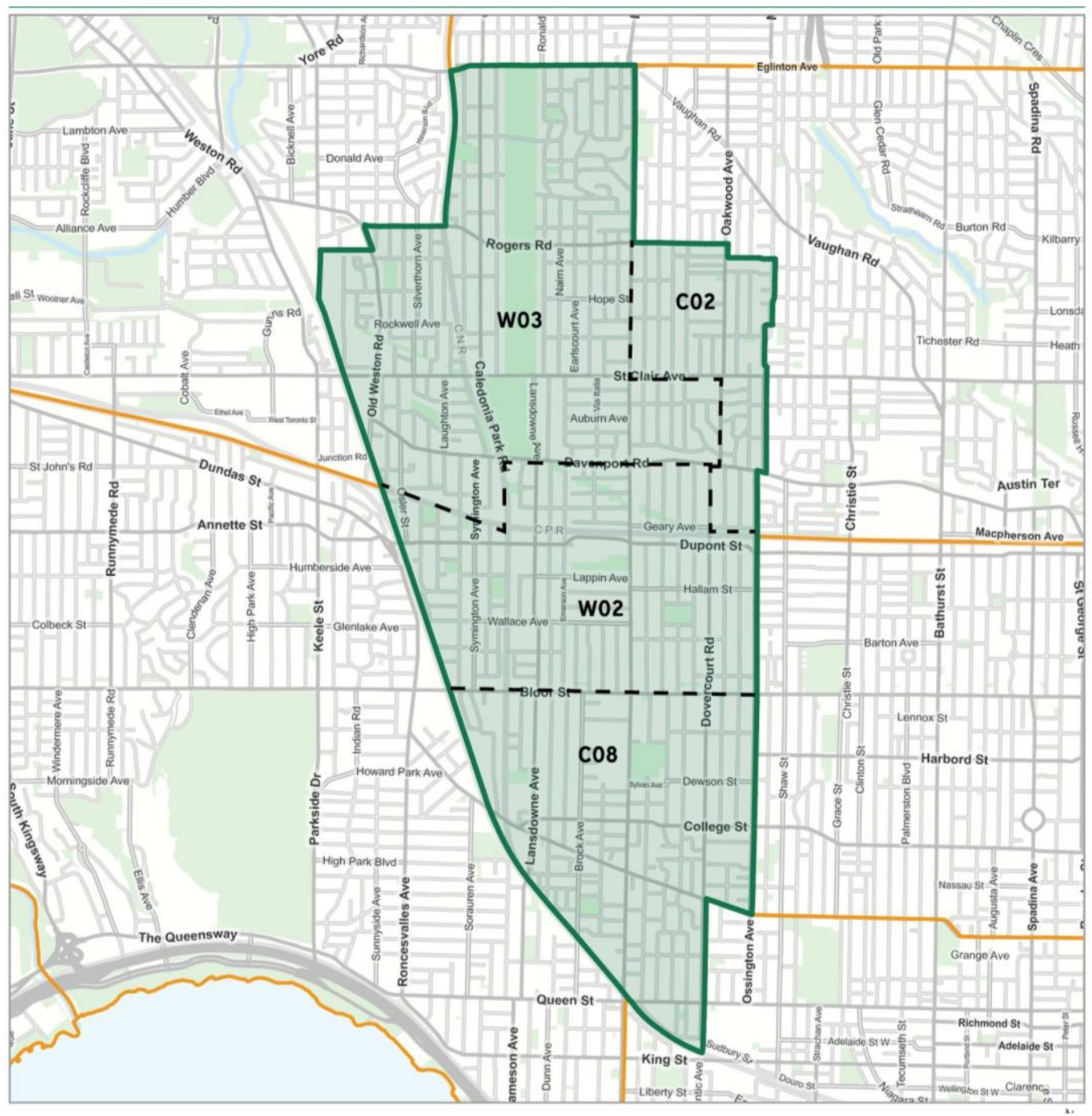




\subsection{1(A) OWNERSHIP ANALYSIS}

With the average recorded household income in Ward 9 of $\$ 80,807$, the maximum affordable purchase price is $\$ 362,100$, assuming 30 per cent affordability ratio of income, at a 10 percent down payment and 5.34\% interest rate over a 25 year amortization period. Highlighted in red in Appendix A are the submarket locations and building typology according to TREB market watch 2018 report at which households can purchase units that would be considered affordable.

To demonstrate this geographically, Figure 25 represents the distribution of housing typology as deemed affordable by the maximum calculated purchase price. Submarkets that are in yellow demonstrate an affordability of condominium apartments, areas with yellow and diagonal hatching show affordability of both condominium apartments and Condominium towns. Green is used to represent areas with affordable co-apartments and red is representative of areas with affordable co-ownership apartments. The diagram shows that there are plenty of opportunities towards the north east and west parts of the City for affordable condominium apartments at the assumed average household income of Ward 9 at $\$ 80,807$. 
Figure 25: Affordable Typologies at Average Ward 9 Income by Submarket as Recorded by TREB Market Watch 2018.

Sources: Author's calculation of affordable income using $30 \%$ of Ward 9 average income, 10 percent down payment and $5.34 \%$ interest rate over a 25 -year amortization period.

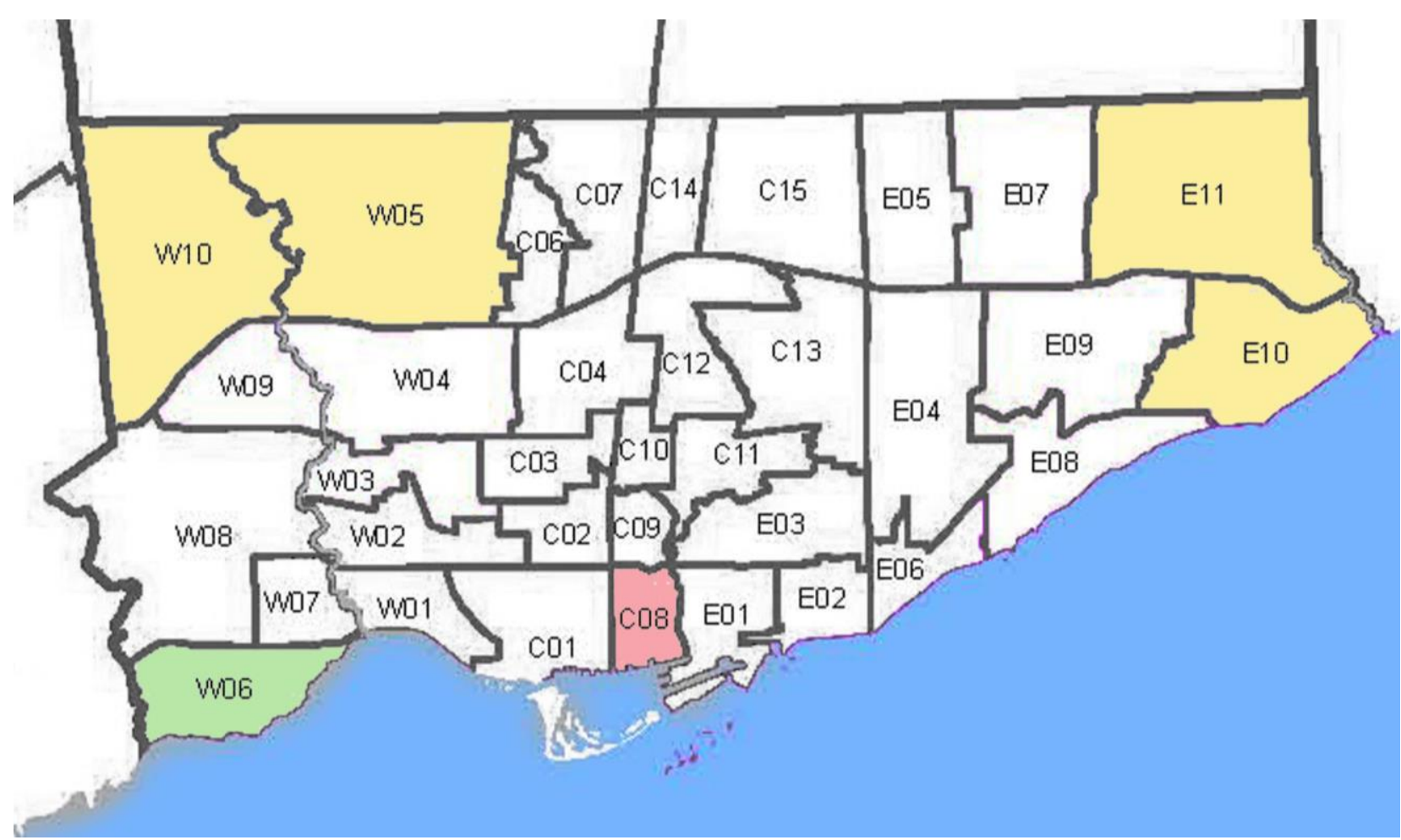

\begin{tabular}{|c|c|c|c|c|c|c|c|}
\hline Colour & Detached & Semi-detached & Condo Town & $\begin{array}{l}\text { Condo } \\
\text { Apartment }\end{array}$ & \begin{tabular}{|l|}
$\begin{array}{l}\text { Row/Town- } \\
\text { house }\end{array}$ \\
\end{tabular} & Co-apartment & $\begin{array}{l}\text { Co-owner } \\
\text { apartment }\end{array}$ \\
\hline & & & & $x$ & & & \\
\hline 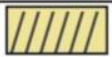 & & & $x$ & $x$ & & & \\
\hline & & & & & & & $x$ \\
\hline & & & $x$ & $x$ & $x$ & & \\
\hline & & $x$ & $x$ & $x$ & $x$ & & \\
\hline & $\mathbf{x}$ & & $x$ & $x$ & & & \\
\hline & & & & $x$ & $x$ & & \\
\hline & & & & $x$ & & & $x$ \\
\hline & $x$ & $x$ & $x$ & $x$ & & & \\
\hline & $x$ & & $x$ & $x$ & & & \\
\hline & $x$ & $x$ & $x$ & $x$ & $x$ & & \\
\hline
\end{tabular}


By comparing the average Ward income and the associated submarkets, the only affordable tenure for purchase is a co-ownership apartment in submarket $\mathrm{C08}$, identified by the boundaries of Yonge Street in the east, Don Valley Parkway in the west, Bloor Street East in the north and Lake Ontario in the south. This means that majority of the population within the Ward are associated with W02, W03 and C02 submarket and at the average Ward household income at 30 per cent ratio, none of the housing typologies are affordable, which could result in overspending or by exploring the rental model.

\subsection{1(B) RENTAL ANALYSIS}

In terms of the rental tenure, based on the average Ward income, the maximum affordable rent is $\$ 2,020$ per month, assuming 30 per cent ration of income divided by 12 to determine affordable monthly rent payment. Appendix B shows rental data is based on TREB Q4 2018 rental market watch, where the affordable housing typology is highlighted in red. Submarkets that are associated with the Ward boundaries are marked in black outline.

As demonstrated in Appendix B, based on 30 per cent of the average Ward household income, the bachelor and one Bedroom tenure is affordable within the entire City. Based on the submarket analysis, at both C08 and C02 which constitutes the southern and eastern portion of the Ward, bachelor typology is affordable. Towards the north in submarket W03, the bachelor tenure records no inventory, but the one-bedroom tenure is also affordable. Contrasting to all the submarkets, W02 which is located in the centre of the Ward demonstrated that none of the tenures are affordable at the average Ward household income.

To demonstrate this geographically, Figure 26 shows the distribution of housing typology as deemed affordable by the above table analysis. Submarkets that are in white demonstrate an affordability of 1 Bachelor only, areas with yellow show affordability of both 1 Bedroom and bachelor units. Areas combining affordability of 1 Bedroom +Bachelor and 2 Bedrooms are in orange, 1 Bedroom +2 Bedrooms are in green, 1 Bedroom +2 Bedroom +3 Bedroom are in red, 1 Bedroom + Bachelor +3 Bedroom are in blue, 1 Bedroom +3 Bedroom are in pink, and finally those coloured white are unaffordable and those with no data are in grey. 
Figure 26: Affordable Typologies at Average Ward 9 Income by Submarket as Recorded by TREB Market Watch 2018.

Sources: Author's calculation of affordable income using $30 \%$ of Ward 9 average income, divided by 12 for monthly rent payment

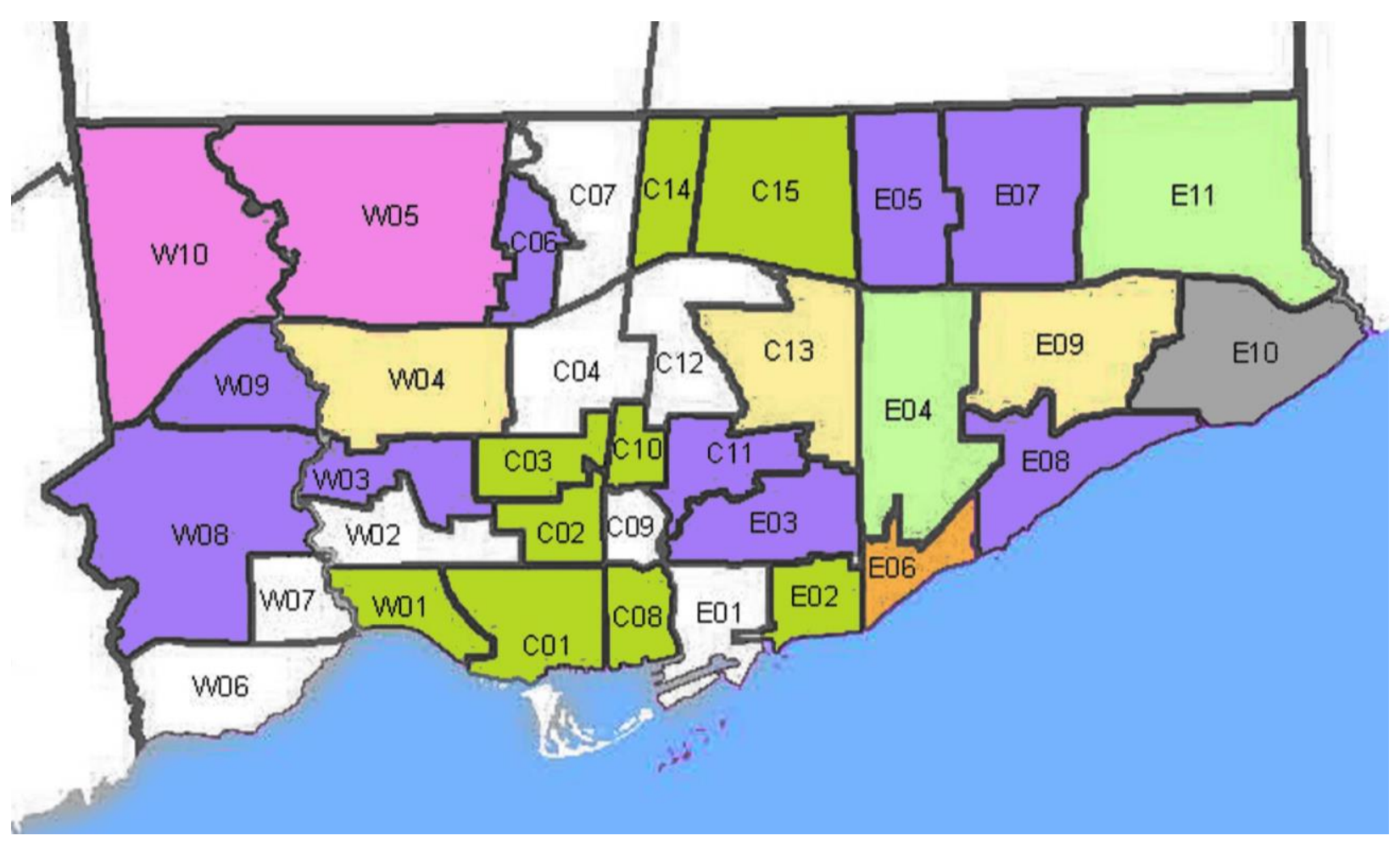

\begin{tabular}{|c|c|c|c|c|}
\hline Colour & Bachelor & 1 Bedroom & 2 Bedroom & 3 Bedroom \\
\hline \hline & $\mathbf{X}$ & & & \\
\hline \hline & $\mathbf{X}$ & $\mathbf{X}$ & & \\
\hline \hline & & $\mathbf{X}$ & & \\
\hline \hline & $\mathbf{X}$ & $\mathbf{X}$ & $\mathbf{X}$ & \\
\hline \hline & & $\mathbf{X}$ & $\mathbf{X}$ & \\
\hline \hline & & $\mathbf{X}$ & $\mathbf{X}$ & $\mathbf{X}$ \\
\hline \hline & $\mathbf{X}$ & $\mathbf{X}$ & & $\mathbf{X}$ \\
\hline \hline & & $\mathbf{X}$ & & $\mathbf{X}$ \\
\hline \hline & & & & \\
\hline
\end{tabular}


Analysis of both the ownership and rental tenure within the Ward demonstrates that at the average Ward income it is likely that most residents living within this geographic area can afford to rent but very unlikely to afford purchasing a house at an affordable ratio of 30 per cent.

\subsection{1(C) INCOME RATIO ANALYSIS}

To compare both ownership and rental tenures at a spending ratio of 30 per cent, 50 per cent and 70 per cent of the average Ward income are used to determine affordability within the applicable submarkets as demonstrated in Table 8. At 50 per cent most of the rental typologies are affordable, while for ownership tenure majority is affordable at 70 per cent spending ratio of income.

Table 8: Affordable Typologies by Submarket as Recorded by TREB Market Watch 2018 at $30 \%, 50 \%$ and $70 \%$ of average Ward 9 income Sources: Author's calculation of affordable income using $30 \%, 50 \%$ and $70 \%$ of Ward 9 average income, assuming 10 percent down payment and $5.34 \%$ interest rate at a 25 -year amortization period for ownership, while dividing the income by 12 for affordable monthly rent payment.

\begin{tabular}{|l|c|c|c|}
$\begin{array}{l}\text { Ward Average } \\
\text { Household Income }\end{array}$ & Income & Cost per month & Purchase Price \\
\hline & $\$ 24,242$ & $\$ 2,020$ & $\$ 362,100$ \\
\hline Spending at 30 per cent & $\$ 40,404$ & $\$ 3,367$ & $\$ 603,600$ \\
\hline Spending at 50 per cent & $\$ 407$ & $\$ 845,200$ \\
\hline Spending at 70 per cent & $\$ 56,565$ & $\$ 4,714$ & \\
\hline
\end{tabular}

\begin{tabular}{|l|c|c|c|c|c|c|c|}
\hline & Detached & Semi detached & $\begin{array}{c}\text { Condominium } \\
\text { Townhouse }\end{array}$ & $\begin{array}{c}\text { Condominium } \\
\text { apartment }\end{array}$ & $\begin{array}{c}\text { Row/Townh } \\
\text { ouse }\end{array}$ & $\begin{array}{c}\text { Co-apartment } \\
\text { apartment }\end{array}$ \\
\hline Toronto W03 & $\$ 727,308$ & $\$ 838,585$ & $\$ 614,667$ & $\$ 432,800$ & - & - \\
\hline Toronto W04 & $\$ 782,983$ & $\$ 808,000$ & $\$ 540,250$ & $\$ 401,919$ & $\$ 600,000$ & - \\
\hline Toronto C02 & $\$ 1,400,000$ & $\$ 1,145,000$ & $\$ 1,097,000$ & $\$ 1,318,999$ & - & - \\
\hline Toronto C08 & - & $\$ 1,559,333$ & $\$ 815,000$ & $\$ 606,765$ & $\$ 1,330,000$ & - \\
\hline
\end{tabular}

\begin{tabular}{|l|c|c|c|c|}
\hline & Bachelor & One Bedroom & Two Bedroom & $\begin{array}{c}\text { Three } \\
\text { Bedroom }\end{array}$ \\
\hline Toronto W03 & - & $\$ 1,900$ & - & $\$ 2,700$ \\
\hline Toronto W04 & $\$ 1,617$ & $\$ 1,882$ & $\$ 2,279$ & $\$ 3,350$ \\
\hline Toronto C02 & $\$ 1,913$ & $\$ 2,508$ & $\$ 4,063$ & $\$ 5,486$ \\
\hline Toronto C08 & $\$ 1,866$ & $\$ 2,238$ & $\$ 3,111$ & $\$ 4,669$ \\
\hline
\end{tabular}


To determine who can afford what typology within the rent tenure, Figure 27 maps out the 10 income deciles along with the corresponding submarket data for the Ward. Figure 28 data demonstrates that all the typologies that lie to the left of the cut off line of the average income are affordable and those to the right are un affordable. The data demonstrates that at 30 per cent income ratio only one typology is affordable for any income bracket below the $8^{\text {th }}$ decile, while at 50 per cent income ratio a lot more options are affordable above the $5^{\text {th }}$ decile.

Figure 27: Affordable Rental Typologies by Submarket as Recorded by TREB Market Watch 2018 at $30 \%, 50 \%$ and $70 \%$ of Average Ward 9 Income and Average Millennial Income.

Sources: Author's calculation of affordable income using $30 \%, 50 \%$ and $70 \%$ of Ward 9 average income, divided by 12 for monthly rent payment

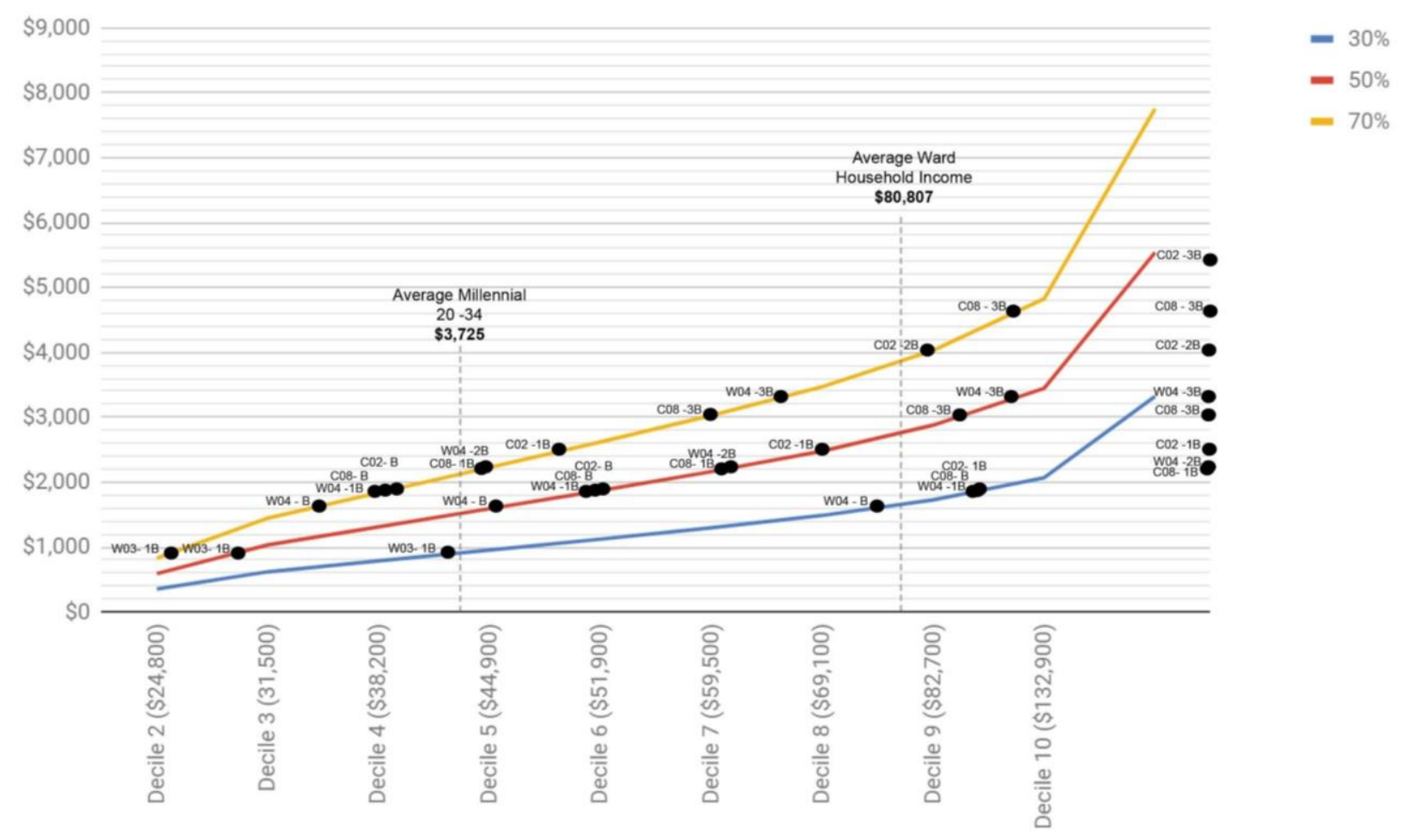

\subsection{1(D) WARD NEW HOUSING SUPPLY ANALYSIS}

Majority of this Ward is within the boundaries of the Little Portugal Neigbourhood (84), Dufferin Grove Neigbourhood (83), Dovercourt-Wallace Emerson-Junction Neighbourhood (93), Corso Italia - Davenport (92), and majority of Weston Pelham Neighbourhood (91). According to CMHC's under construction inventory by dwelling type for 2018, a total new housing supply of 6 units are under construction (Canada Mortgage and Housing Corporation (CMHC), 2018c). Table 9 demonstrates the breakdown results for new supply within the neighbourhood; 
Table 9: New Housing under Construction Inventory by Dwelling Type by Neighbourhood 2018 Sources: Canada Mortgage and Housing Corporation (CMHC) Housing Market Information Portal.

\begin{tabular}{|l|c|c|c|c|c|}
\hline Neighbourhood & Single Semi detached & Row & Apartment & Total \\
\hline $\begin{array}{l}\text { Dufferin Grove/Little } \\
\text { Portugal }\end{array}$ & 0 & 0 & 0 & 2 & 2 \\
\hline $\begin{array}{l}\text { Dovercourt/ } \\
\text { Davenport/Junction }\end{array}$ & 1 & 0 & 0 & 1 & 2 \\
\hline Weston & 2 & 0 & 0 & 0 & 2 \\
\hline Total & 3 & 0 & 0 & 3 & 6 \\
\hline
\end{tabular}

Based on the above data, the only available choices of new housing typology for the Ward population are only 3 apartments and 3 single detached units. Thus, the supply of new housing under construction is very scarce in this area making it very difficult for millennials to choose a tenure that both meets their needs and is affordable.

\subsubsection{WARD 10 - SPADINA - FORT YORK}

Ward 10 is comprised of a number of prominent and historic areas including Liberty Village, Distillery District, the Grange and Toronto Islands. It is bound from the north by Dundas Street West, Bay Street and the Esplande. To the west is Davenport Road, Ossington Avenue, Winona Drive and to the east are the Port lands. To the southern boundary is Lake Ontario and the Toronto Islands. The ward is under the jurisdiction of the elected official, Councillor Joe Cressy. Layering Ward 10 boundary on top of the TREB submarket boundaries, submarkets C01, a small portion of W01 and W08 highlighted with a black outline highlighted with a black outline on are their boundaries on Figure 28 and in Appendix C and D. These submarkets make up the relative markets to which affordability should be compared. 
Figure 28: Ward10 Profile with Overlaid TREB Submarket Boundary Sources: City of Toronto Ward 10 Profile and TREB Submarket boundaries

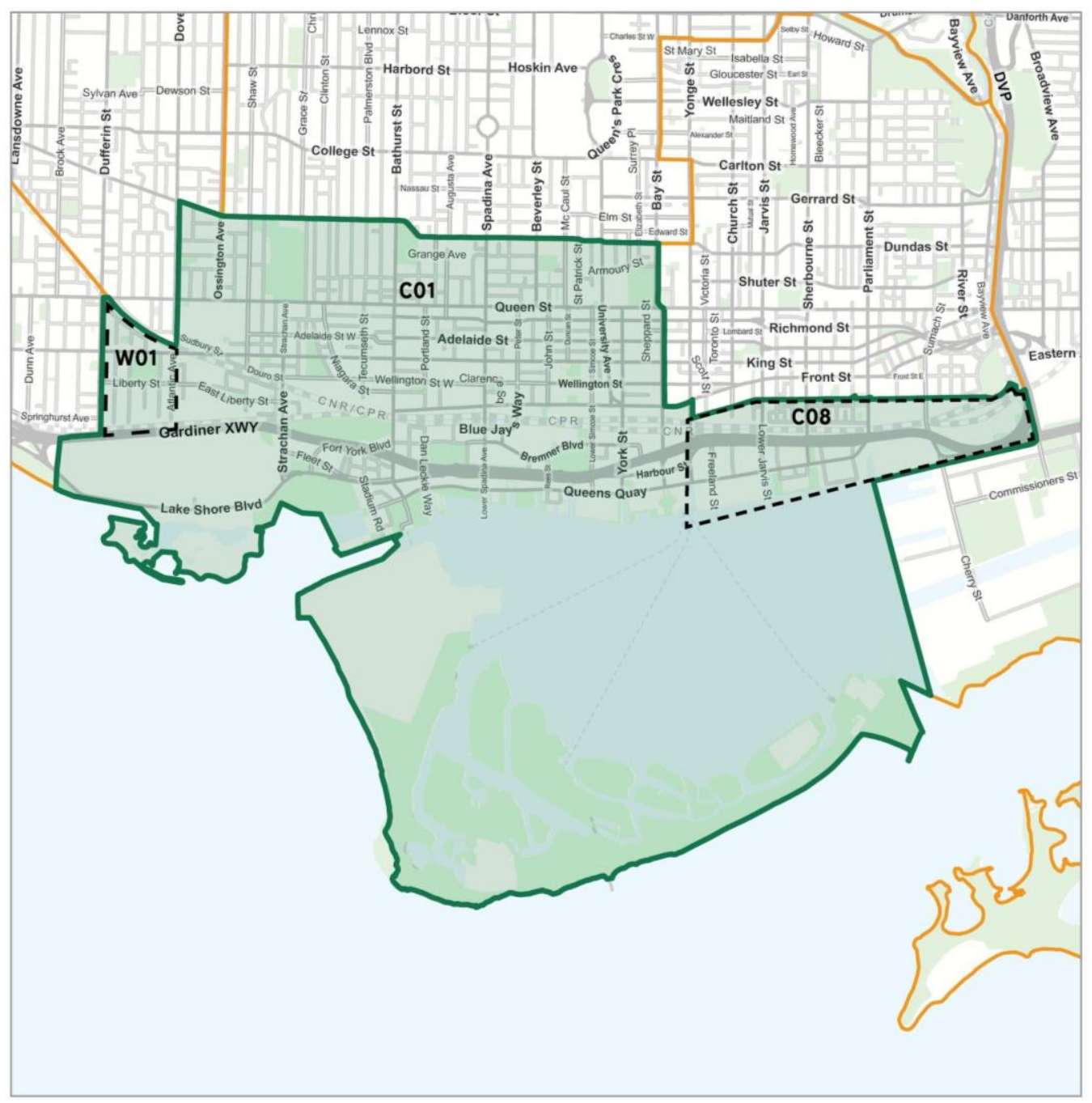

\subsection{2(A) OWNERSHIP ANALYSIS}

At an average household income of $\$ 103,047$, the maximum affordable purchase price of $\$ 461,800$ assuming 10 percent down payment and $5.34 \%$ interest rate over a 25 year amortization period. Highlighted in red in Appendix $\mathrm{C}$ are the submarket locations and building typology according to TREB market watch 2018 report at which households can purchase units that would be considered affordable.

To demonstrate this geographically, Figure 29 represents the distribution of housing typology as deemed affordable by the maximum calculated purchase price. Submarkets that are in yellow demonstrate an affordability of condominium apartments, areas with yellow and diagonal hatching show affordability of both condominium apartments and Condominium towns. Green is 
used to represent areas with affordable co-apartments and red is representative of areas with affordable co-ownership apartments.

Figure 29: Affordable Typologies at Average Ward 10 Income by Submarket as Recorded by TREB Market Watch 2018.

Sources: Author's calculation of affordable income using 30\% of Ward 10 average income, 10 percent down payment and $5.34 \%$ interest rate over a 25 -year amortization period.

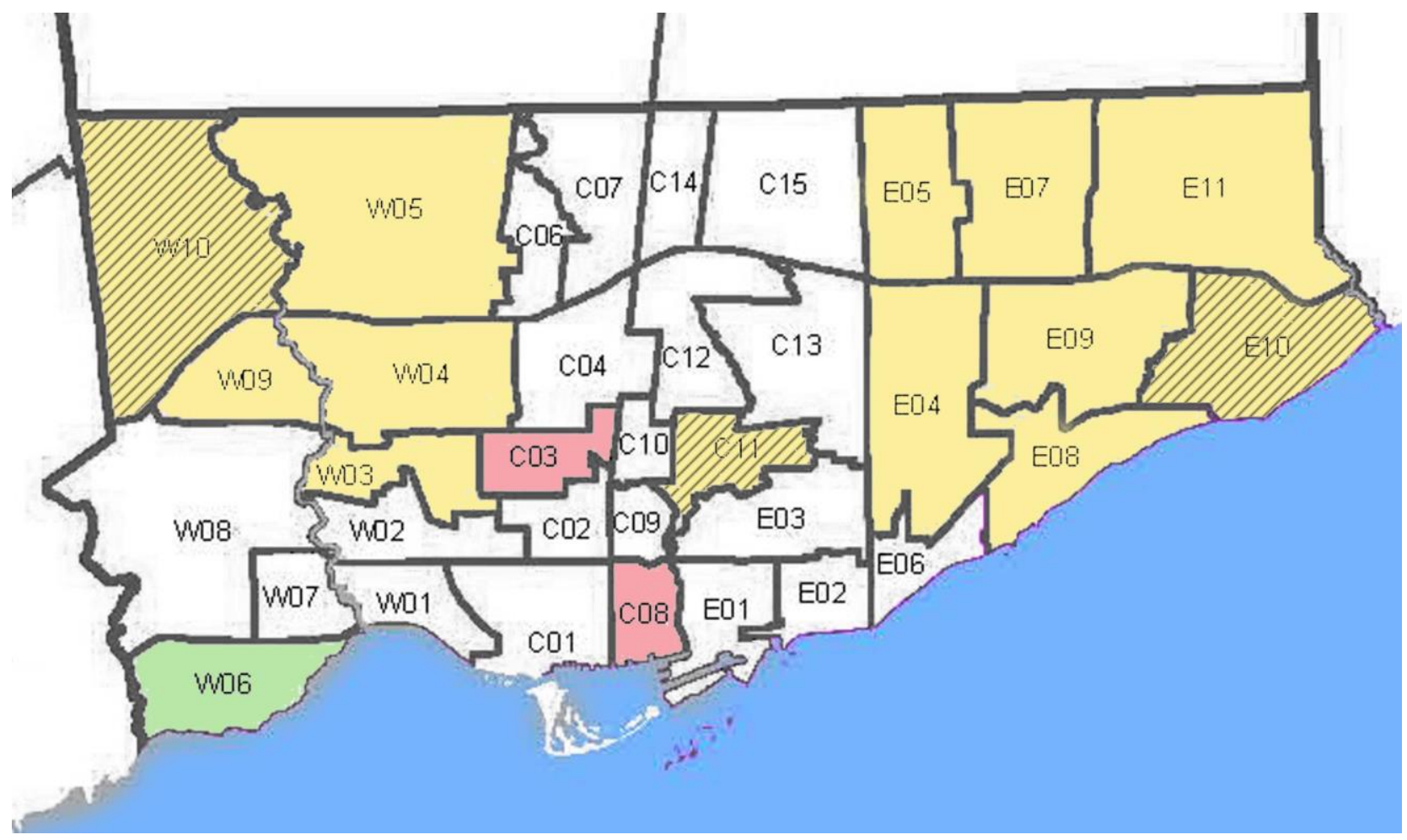

\begin{tabular}{|c|c|c|c|c|c|c|c|}
\hline Colour & Detached & Semi-detached & Condo Town & $\begin{array}{l}\text { Condo } \\
\text { Apartment }\end{array}$ & $\begin{array}{l}\begin{array}{l}\text { Row/Town- } \\
\text { house }\end{array} \\
\end{array}$ & Co-apartment & $\begin{array}{l}\text { Co-owner } \\
\text { apartment }\end{array}$ \\
\hline & & & & $x$ & & & \\
\hline 111 & & & $\mathbf{x}$ & $x$ & & & \\
\hline & & & & & & & $x$ \\
\hline & & & $x$ & $x$ & $x$ & & \\
\hline & & $x$ & $x$ & $x$ & $x$ & & \\
\hline & $x$ & & $x$ & $x$ & & & \\
\hline & & & & $x$ & $x$ & & \\
\hline & & & & $x$ & & & $x$ \\
\hline & $x$ & $x$ & $x$ & $x$ & & & \\
\hline & $x$ & & $x$ & $\mathbf{x}$ & & & \\
\hline & $x$ & $x$ & $\mathbf{x}$ & $x$ & $\mathbf{x}$ & & \\
\hline
\end{tabular}


Figure 29 shows that there are plenty of opportunities in the east and west, less the central corridor of the City for affordable condominium apartments at the assumed average household income of Ward 10 at $\$ 103,047$. By comparing the average Ward income and the associated submarkets, the only affordable tenure for purchase is a co-ownership apartment in submarket C08 identified by the boundaries of Yonge Street in the east, Don Valley Parkway in the west, Bloor Street East in the north and Lake Ontario in the south. This however also means that majority of the population within the Ward are associated with C01 submarket and at the average Ward household income at 30 per cent ratio, none of the housing typologies are affordable, which could result in overspending or by exploring the rental model.

\subsection{2(B) RENTAL ANALYSIS}

In terms of the rental tenure, the maximum affordable rent is $\$ 2,576$ per month, assuming 30 per cent ration of income divided by 12 to determine affordable monthly rent payment. Appendix D shows rental data is based on TREB Q4 2018 rental market watch, where the affordable housing typology is highlighted in red. Submarkets that are associated with the Ward boundaries are marked in black outline.

As demonstrated in Appendix D, based on 30 per cent of the average Ward household income, the one Bedroom tenure is affordable within the entire City. Based on the submarket analysis, C01 which constitutes majority of the Ward, both bachelor and 1 Bedroom tenures are affordable, same as in submarket C06. According to data on submarket W08, bachelor tenure does not have any recorded data; however, both the one Bedroom and two Bedroom are affordable.

To demonstrate this geographically, Figure 30 shows the distribution of housing typology as deemed affordable by the above table analysis. Submarkets that are in purple demonstrate an affordability of 1 Bedroom only, areas with yellow show affordability of both 1 Bedroom and Bachelor units. Areas combining affordability of 1 Bedroom +Bachelor and 2 Bedrooms are in orange, 1 Bedroom + 2 Bedrooms are in green, 1 Bedroom +2 Bedroom +3 Bedroom are in red, 1 Bedroom + Bachelor + 3 Bedrooms are in blue, 1 Bedroom + 3 Bedrooms are in pink, and finally those coloured white are unaffordable and those with no data are in grey. 
Figure 30: Affordable Typologies at Average Ward 10 Income by Submarket as Recorded by TREB Market Watch 2018.

Sources: Author's calculation of affordable income using $30 \%$ of Ward 10 average income, divided by 12 for monthly rent payment

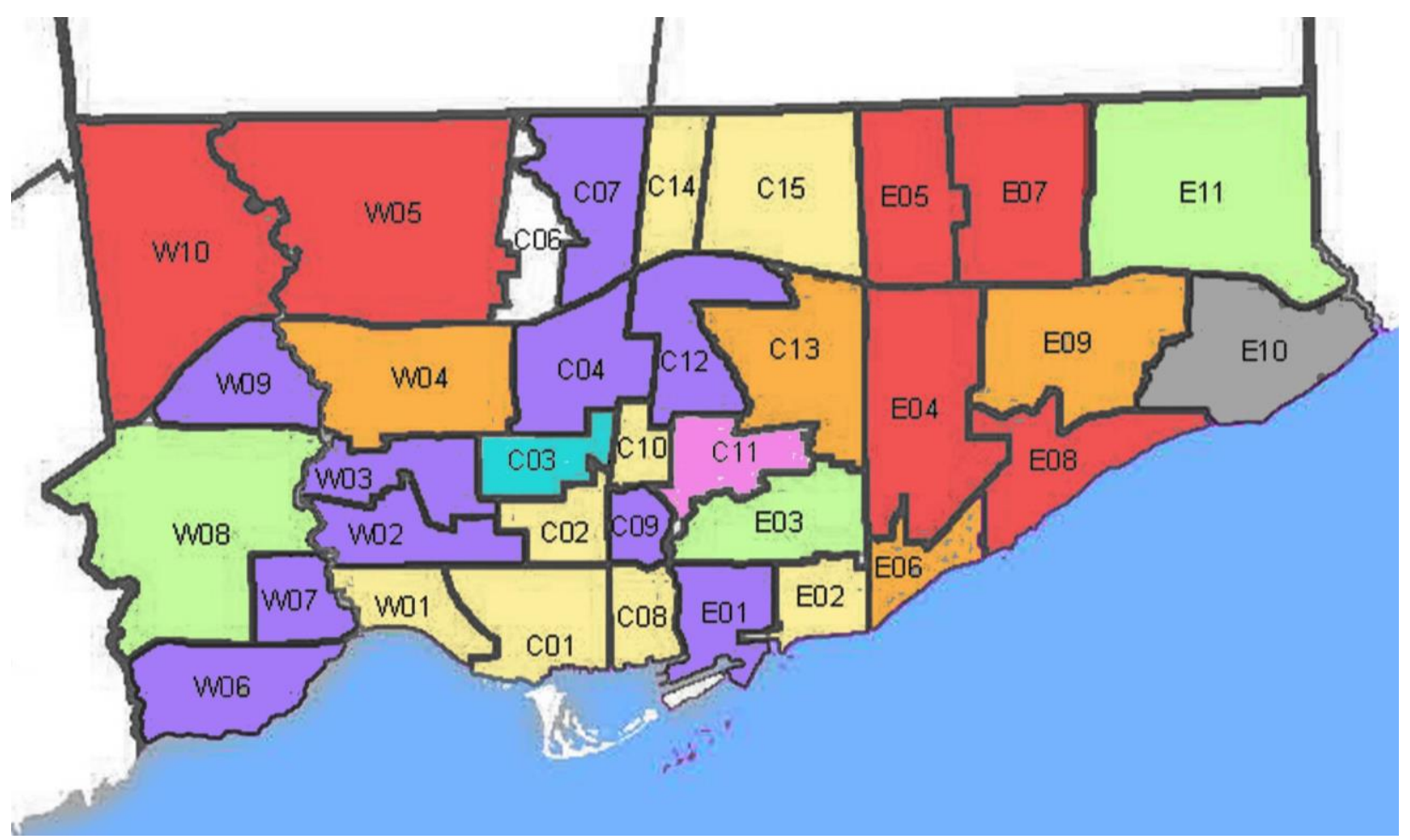

\begin{tabular}{|c|c|c|c|c|}
\hline Colour & Bachelor & 1 Bedroom & 2 Bedroom & 3 Bedroom \\
\hline \hline & $\mathbf{X}$ & & & \\
\hline \hline & $\mathbf{X}$ & $\mathbf{X}$ & & \\
\hline \hline & & $\mathbf{X}$ & & \\
\hline \hline & $\mathbf{X}$ & $\mathbf{X}$ & $\mathbf{X}$ & \\
\hline \hline & & $\mathbf{X}$ & $\mathbf{X}$ & \\
\hline \hline & & $\mathbf{X}$ & $\mathbf{x}$ & $\mathbf{X}$ \\
\hline \hline & $\mathbf{X}$ & $\mathbf{X}$ & & $\mathbf{X}$ \\
\hline \hline & & $\mathbf{X}$ & & $\mathbf{x}$ \\
\hline \hline & & & & \\
\hline
\end{tabular}

Figure 30 shows that there are plenty of opportunities in the central portion for 1 Bedroom options while variety of 1 Bedroom+bachelor +2 Bedrooms or 1 Bedroom +2 Bedrooms +3 Bedrooms is seen more towards the east and west, at the assumed average household income 
of Ward 10 at $\$ 103,047$. Analysis of both the ownership and rental tenure within the Ward demonstrates that at the average Ward income it is likely that most residents living within this geographic area can afford to rent but very unlikely to afford purchasing a house at an affordable ratio.

\subsection{2(C) INCOME RATIO ANALYSIS}

To compare both ownership and rental tenures at a spending ratio of 30 per cent, 50 per cent and 70 per cent of the average Ward income are used to determine affordability within the applicable submarkets as demonstrated in Table 10. At 50 per cent most of the rental typologies are affordable, while for ownership tenure majority is affordable at 70 per cent spending ratio of income.

Table 10: Affordable Typologies by Submarket as Recorded by TREB Market Watch 2018 at $30 \%, 50 \%$ and $70 \%$ of Average Ward 10 income : Affordable Typologies by Submarket as Recorded by TREB Market Watch 2018 at $30 \%, 50 \%$ and $70 \%$ of Average Ward 10 Income Sources: Author's calculation of affordable income using $30 \%, 50 \%$ and $70 \%$ of Ward 10 average income, assuming 10 percent down payment and $5.34 \%$ interest rate at a 25 -year amortization period for ownership, while dividing the income by 12 for affordable monthly rent payment.

\section{Ward Average}

Household Income

$$
\$ 103,047
$$

\begin{tabular}{|l|r|r|r|}
\hline & \multicolumn{1}{|l|}{ Income } & \multicolumn{1}{l|}{$\begin{array}{l}\text { Cost per } \\
\text { month }\end{array}$} & Purchase Price \\
\hline Spending at 30 per cent & $\$ 30,914$ & $\$ 2,576$ & $\$ 461,800$ \\
\hline Spending at 50 per cent & $\$ 51,524$ & $\$ 4,294$ & $\$ 769,800$ \\
\hline Spending at 70 per cent & $\$ 72,133$ & $\$ 6,011$ & $\$ 1,333,200$ \\
\hline
\end{tabular}

\begin{tabular}{|c|c|c|c|c|c|c|c|}
\hline & Detached & $\begin{array}{l}\text { Semi } \\
\text { detached }\end{array}$ & $\begin{array}{l}\text { Condominium } \\
\text { Townhouse }\end{array}$ & $\begin{array}{l}\text { Condominium } \\
\text { apartment }\end{array}$ & $\begin{array}{l}\text { Row/Town } \\
\text { house }\end{array}$ & Co-apartment & $\begin{array}{l}\text { Co-ownership } \\
\text { apartment }\end{array}$ \\
\hline Toronto W01 & $\$ 1,429,250$ & $\$ 1,063,000$ & $\$ 672,000$ & $\$ 647,631$ & $\$ 1,050,000$ & - & - \\
\hline Toronto C01 & $\$ 1,975,296$ & $\$ 1,340,600$ & $\$ 969,663$ & $\$ 730,564$ & $\$ 1,257,813$ & - & - \\
\hline Toronto C08 & - & $\$ 1,559,333$ & $\$ 815,000$ & $\$ 606,765$ & $\$ 1,330,000$ & - & $\$ 320,000$ \\
\hline
\end{tabular}

\begin{tabular}{|l|r|r|r|r|}
\hline & Bachelor & $\begin{array}{l}\text { One } \\
\text { Bedroom }\end{array}$ & \multicolumn{1}{l|}{$\begin{array}{l}\text { Two } \\
\text { Bedroom }\end{array}$} & \multicolumn{1}{l|}{$\begin{array}{l}\text { Three } \\
\text { Bedroom }\end{array}$} \\
\hline Toronto W01 & $\$ 1,450$ & $\$ 2,121$ & $\$ 2,780$ & $\$ 4,350$ \\
\hline Toronto C01 & $\$ 1,877$ & $\$ 2,319$ & $\$ 3,312$ & $\$ 4,330$ \\
\hline Toronto C08 & $\$ 1,866$ & $\$ 2,238$ & $\$ 3,111$ & $\$ 4,669$ \\
\hline
\end{tabular}


To determine who can afford what typology within the rent tenure, Figure 31 maps out the 10 income deciles along with the corresponding submarket data for the Ward. The data shows that at 30 per cent income ratio only one typology is affordable for an income bracket below the 9th decile, while at 50 per cent income ratio a lot more options are affordable above the 5th decile.

Figure 31: Affordable Rental Typologies by Submarket as Recorded by TREB Market Watch 2018 at $30 \%, 50 \%$ and $70 \%$ of Average Ward 10 Income and Average Millennial Income.

Sources: Author's calculation of affordable income using $30 \%, 50 \%$ and $70 \%$ of Ward 10 average income, divided by 12 for monthly rent payment

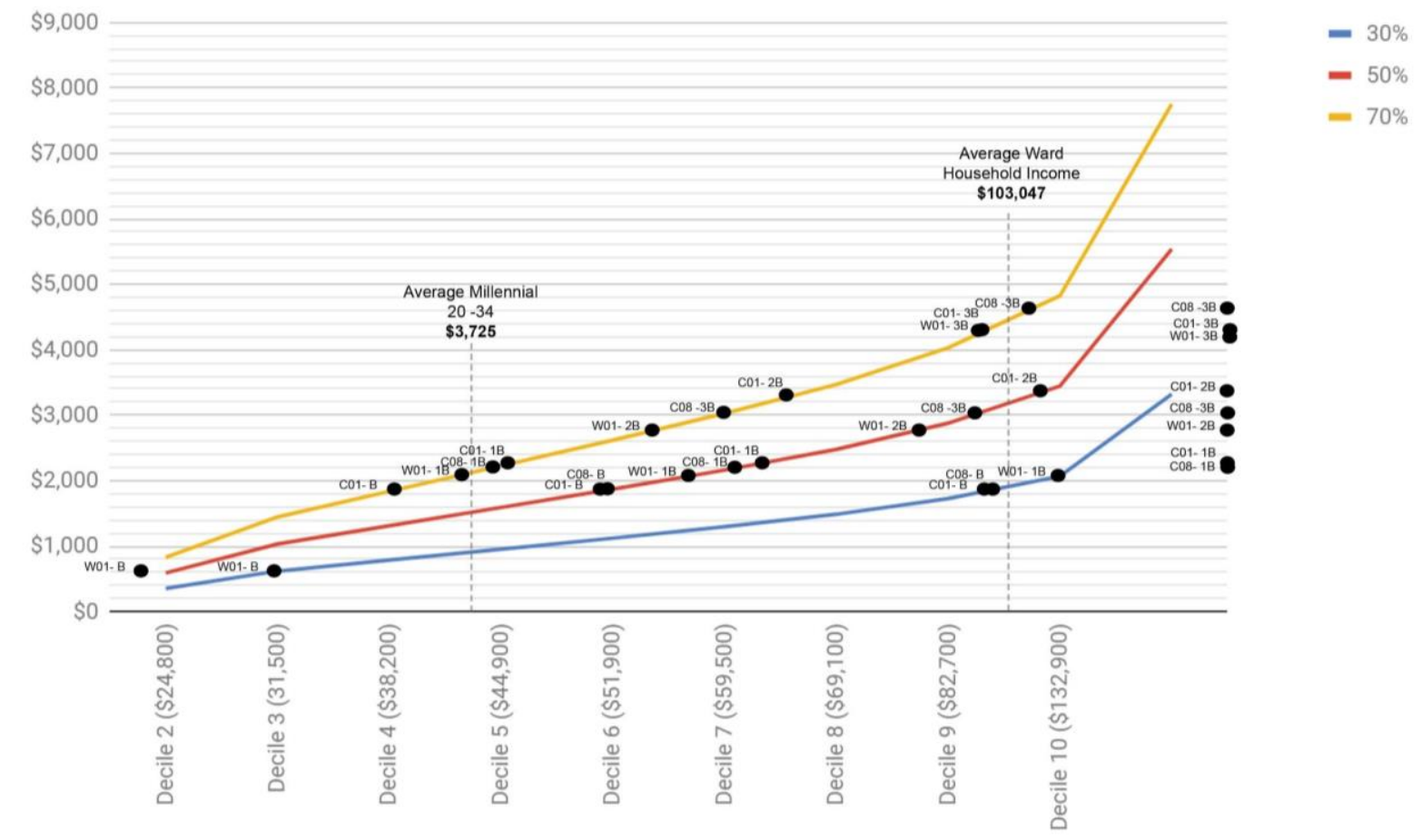

\subsection{2(D) WARD NEW HOUSING SUPPLY ANALYSIS}

Majority of this Ward is within the boundaries of the Waterfront Communities Neighbourhood (77) and portions of the Bay Street Corridor (76) and Church-Yonge Corridor (75). According to CMHC's under construction inventory by dwelling type for 2018 , a total new housing supply of 20,454 units are under construction (Canada Mortgage and Housing Corporation (CMHC), 2018c). Table 11 demonstrates the break- down of results for new supply within the neighbourhood; 
Table 11: New Housing Under Construction Inventory by Dwelling Type by Neighbourhood 2018 Sources: Canada Mortgage and Housing Corporation (CMHC) Housing Market Information Portal.

\begin{tabular}{|c|c|c|c|c|c|}
\hline Neighbourhood & Single & Semi detached & Row & Apartment & Total \\
\hline $\begin{array}{l}\text { Waterfront } \\
\text { Communities }\end{array}$ & 1 & 0 & 0 & 5,610 & 5,611 \\
\hline Bay Corridor & 0 & 0 & 0 & 174 & 174 \\
\hline Church Yonge & 1 & 0 & 0 & 5,330 & 5,331 \\
\hline Total & 2 & 0 & 0 & 11,114 & 20,454 \\
\hline
\end{tabular}

Based on the above data, the only available choices of new housing typology for the Ward population are apartments, with only 2 units of single detached units. Thus, making it very difficult for millenials to choose a tenure that both meets their needs and is affordable.

\subsubsection{WARD 11 - UNIVERSITY ROSEDALE}

Ward 11 is interestingly located in the heart of Toronto as it spans to capture Little Italy in the west being bordered by Ossington Avenue. Also to the North the ward boundaries capture Rosedale neighbourhood as well as Yonge Street, Mount Pleasant Cemetery and Moore Park Ravine. To the east side are Bayview Avenue, the Don River, Rosedale Valley Road, Bloor Street East, Charles, as well as College Street, Yonge Street and Dundas Street to the south. The Ward is under the jurisdiction of the elected Councillor Mike Layton. Layering Ward 11 boundary on top of the TREB submarket boundaries, submarkets C01, C02, C09, and small portions of C08, C11 and W02 highlighted with a black outline highlighted with a black outline on are their boundaries on Figure 32 and in Appendix $E$ and F. These submarkets make up the relative markets to which affordability should be compared. 
Figure 32: Ward11 Profile with Overlaid TREB Submarket Boundary. Sources: City of Toronto Ward 11 Profile and TREB Submarket boundaries.

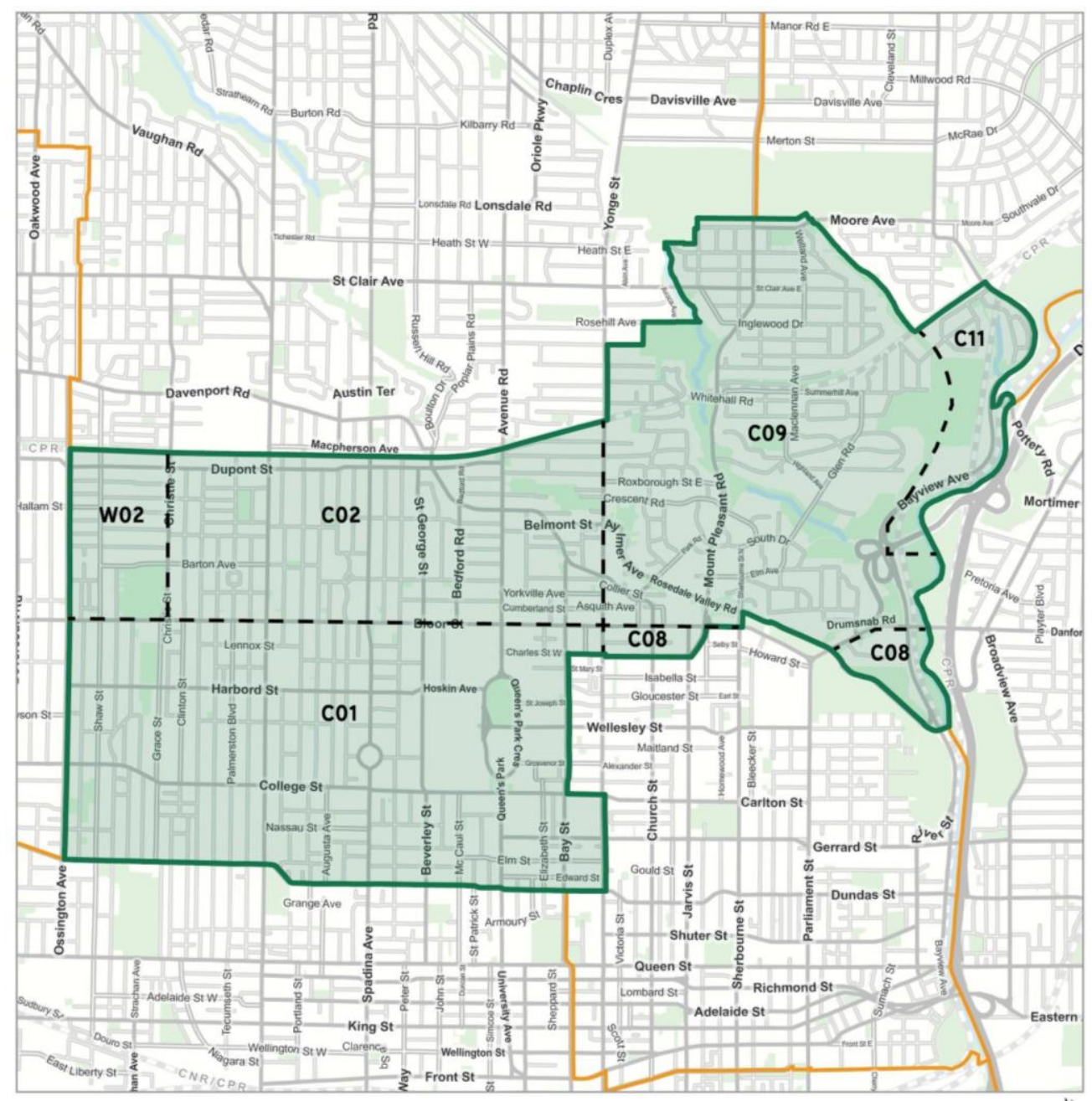

\subsection{3(A) OWNERSHIP ANALYSIS}

At an average household income of $\$ 170,832$, the maximum affordable purchase price of $\$ 765,800$ assuming, 10 percent down payment and 5.34 per cent interest rate over a 25 -year amortization period. Highlighted in red in Appendix E are the submarket locations and tenure at which households can purchase units that would be considered affordable.

To demonstrate this geographically, Figure 32 shows the distribution of housing typology as deemed affordable by the maximum calculated purchase price. Submarkets that are in yellow demonstrate an affordability of condominium apartments, areas with yellow and diagonal hatching show affordability of both condominium apartments and condominium towns. Pink is representative of areas with affordable combination of semidetached, condominium towns, and condominium apartment. 
Figure 32: Affordable Typologies at Average Ward 11 Income by Submarket as Recorded by TREB Market Watch 2018.

Sources: Author's calculation of affordable income using 30\% of Ward 11 average income, 10 percent down payment and $5.34 \%$ interest rate over a 25 -year amortization period.

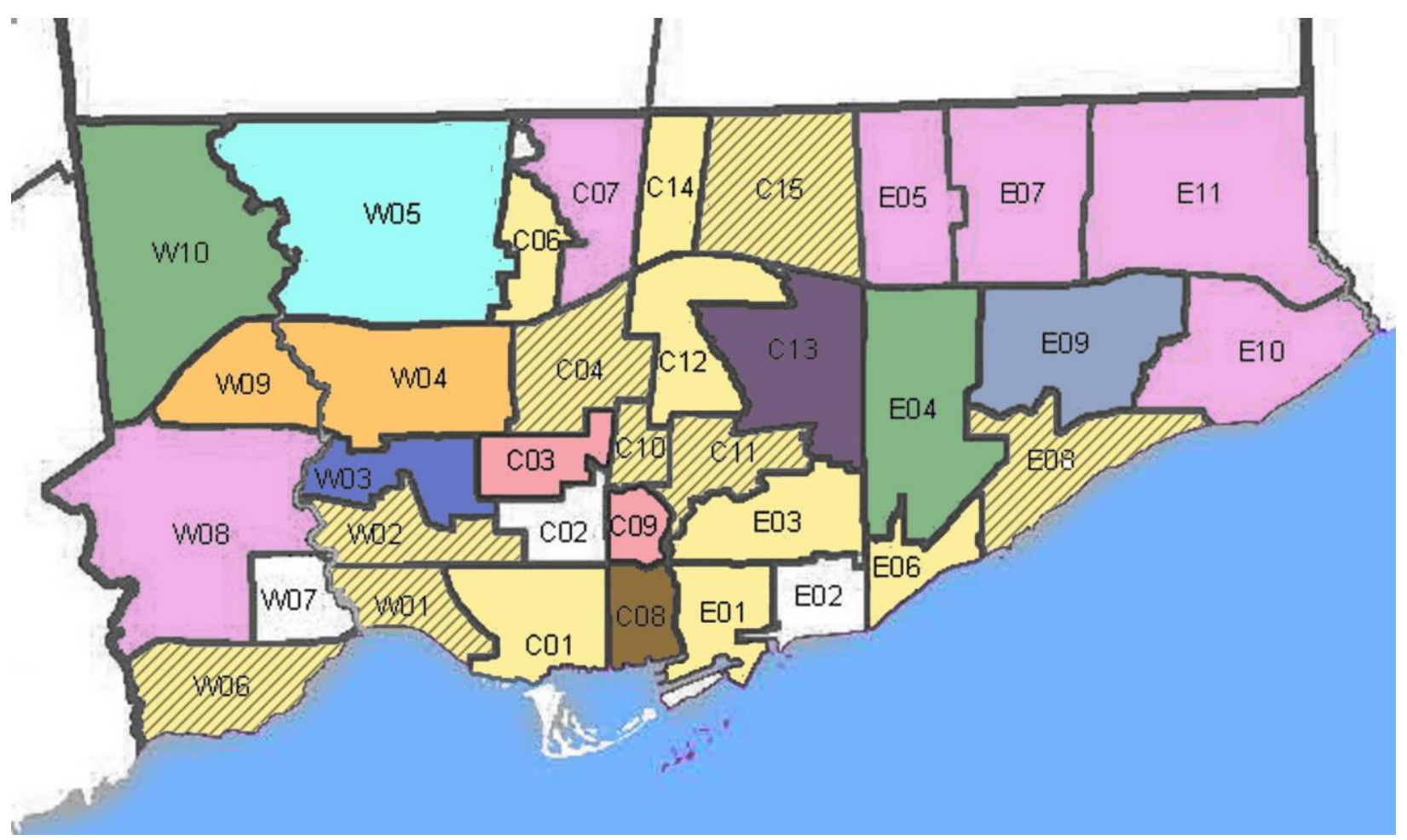

\begin{tabular}{|c|c|c|c|c|c|c|c|}
\hline Colour & Detached & Semi-detached & Condo Town & \begin{tabular}{|l}
$\begin{array}{l}\text { Condo } \\
\text { Apartment }\end{array}$ \\
\end{tabular} & $\begin{array}{l}\text { Row/Town- } \\
\text { house }\end{array}$ & Co-apartment & $\begin{array}{l}\text { Co-owner } \\
\text { apartment }\end{array}$ \\
\hline & & & & $x$ & & & \\
\hline $\mathrm{WIII}$ & & & $x$ & $x$ & & & \\
\hline & & & & & & & $x$ \\
\hline & & & $x$ & $x$ & $x$ & & \\
\hline & & $x$ & $x$ & $x$ & $\mathbf{x}$ & & \\
\hline & $x$ & & $x$ & $x$ & & & \\
\hline & & & & $x$ & $x$ & & \\
\hline & & & & $x$ & & & $x$ \\
\hline & $x$ & $x$ & $x$ & $x$ & & & \\
\hline & $\mathbf{x}$ & & $x$ & $x$ & & & \\
\hline & $\boldsymbol{X}$ & $x$ & $x$ & $x$ & $x$ & & \\
\hline
\end{tabular}


Figure 32 shows that there are opportunities in purchasing a condo apartment unit in the central section, while for the same amount (assumed average household income of Ward 11 at $\$ 170,832$.) a lot more variety of typology units can be found in the far east.

By comparing the average Ward income and the associated submarkets, only condominium apartments are in C01, and co-ownership apartments in C09, presented at market rate are affordable to a household earning the average income at 30 per cent ratio, which could result in overspending or by exploring the rental model. None of the typologies offered in C02 are affordable for purchase.

\subsection{3(B) RENTAL ANALYSIS}

In terms of the rental tenure, the following the maximum affordable rent is $\$ 4,271$ per month, assuming 30 per cent ration of income divided by 12 to determine affordable monthly rent payment. Appendix F shows rental data is based on TREB Q4 2018 rental market watch, where the affordable housing typology is highlighted in red. Submarkets that are associated with the Ward boundaries are marked in black outline.

As demonstrated in Appendix F, based on 30 per cent of the average Ward household income, the one Bedroom tenure is affordable within the entire City. Based on the submarket analysis, C08 which is representative of the entire submarket for this Ward, only bachelor unit typology is affordable.

To demonstrate this geographically, Figure 33shows the distribution of housing typology as deemed affordable by the above table analysis. Submarkets that are in purple demonstrate an affordability of 1 Bedrooms only, areas with yellow show affordability of both 1 Bedroom and bachelor units. Areas combining affordability of 1 Bedroom +Bachelor and 2 Bedrooms are in orange, 1 Bedroom + 2 Bedrooms are in green, 1 Bedroom +2 Bedroom +3 Bedroom are in red, 1 Bedroom + Bachelor + 3 Bedroom are in blue, 1 Bedroom+3 Bedroom are in pink, and finally those coloured white are unaffordable and those with no data are in grey. 
Figure 33: Affordable Typologies at Average Ward 11 Income by Submarket as Recorded by TREB Market Watch 2018.

Sources: Author's calculation of affordable income using $30 \%$ of Ward 11 average income, divided by 12 for monthly rent payment

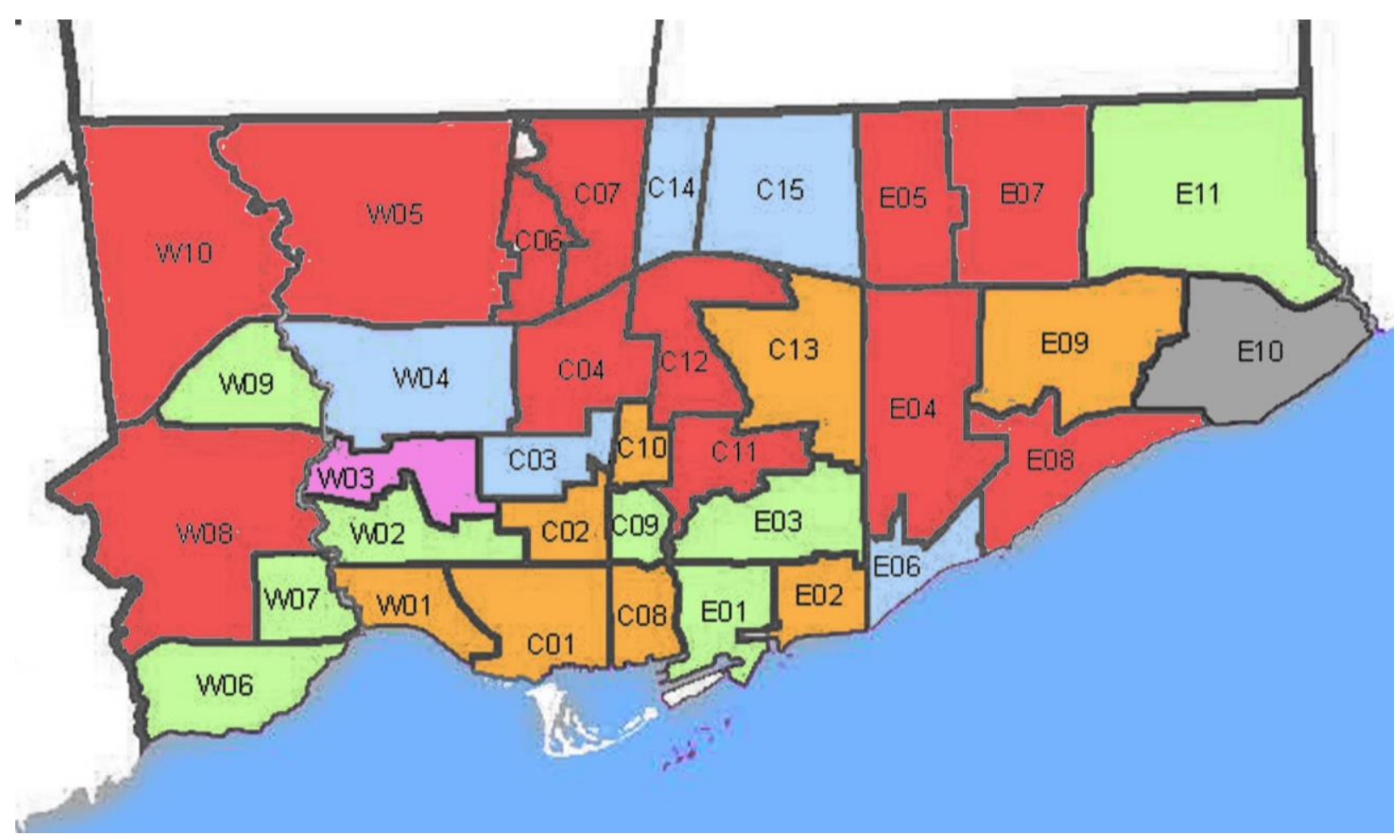

\begin{tabular}{|c|c|c|c|c|}
\hline Colour & Bachelor & 1 Bedroom & 2 Bedroom & 3 Bedroom \\
\hline \hline & $\mathbf{X}$ & & & \\
\hline \hline & $\mathbf{X}$ & $\mathbf{X}$ & & \\
\hline \hline & & $\mathbf{X}$ & & \\
\hline \hline & $\mathbf{X}$ & $\mathbf{X}$ & $\mathbf{X}$ & \\
\hline \hline & & $\mathbf{X}$ & $\mathbf{X}$ & \\
\hline \hline & & $\mathbf{X}$ & $\mathbf{X}$ & $\mathbf{X}$ \\
\hline \hline & $\mathbf{X}$ & $\mathbf{X}$ & & $\mathbf{X}$ \\
\hline \hline & & $\mathbf{X}$ & & $\mathbf{X}$ \\
\hline \hline & & & & \\
\hline
\end{tabular}

Figure 33 shows that although the average household Ward income at $\$ 170,832$ is higher than the average City of Toronto income at $\$ 102,721$ by 40 per cent, along the southern central part of the city, the affordable typologies are bachelor, 1 Bedroom and 2 Bedrooms, but none are 
three Bedrooms. The 3 Bedroom typology is seen in more abundance towards the west and north.

\subsection{3(C) INCOME RATIO ANALYSIS}

To compare both ownership and rental tenures at a spending ratio of 30 per cent, 50 per cent and 70 per cent of the average Ward income to determine affordability within the applicable submarkets as demonstrated by Table 12. At 50 per cent all of the rental typologies are affordable. Due to the high income majority of ownership tenure is affordable at 50 per cent and 70 per cent spending ratio of income.

Table 12: Affordable Typologies by Submarket as Recorded by TREB Market Watch 2018 at $30 \%, 50 \%$ and $70 \%$ of Average Ward 11 Income

Sources: Author's calculation of affordable income using $30 \%, 50 \%$ and $70 \%$ of Ward 11 average income, assuming 10 percent down payment and $5.34 \%$ interest rate at a 25 -year amortization period for ownership, while dividing the income by 12 for affordable monthly rent payment.

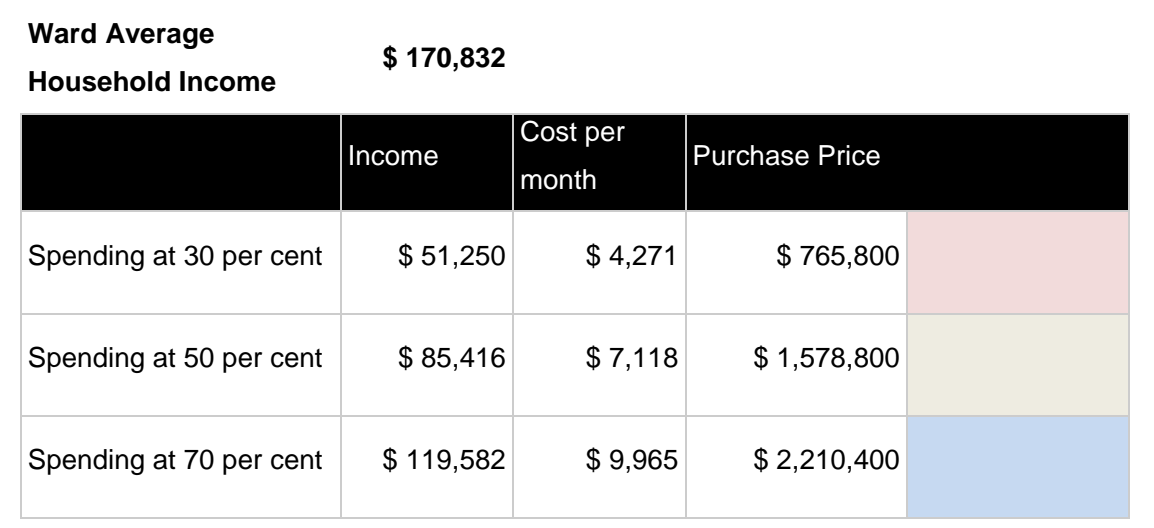

\begin{tabular}{|c|c|c|c|c|c|c|c|}
\hline & Detached & $\begin{array}{l}\text { Semi } \\
\text { detached }\end{array}$ & $\begin{array}{l}\text { Condominium } \\
\text { Townhouse }\end{array}$ & $\begin{array}{l}\text { Condominium } \\
\text { apartment }\end{array}$ & $\begin{array}{l}\text { Row/Townh } \\
\text { ouse }\end{array}$ & $\begin{array}{l}\text { Co- } \\
\text { apartment }\end{array}$ & $\begin{array}{l}\text { Co-ownership } \\
\text { apartment }\end{array}$ \\
\hline Toronto W02 & $\$ 1,139,167$ & $\$ 997,778$ & $\$ 681,250$ & $\$ 655,000$ & $\$ 866,500$ & - & - \\
\hline Toronto C01 & $\$ 1,975,296$ & $\$ 1,340,600$ & $\$ 969,663$ & $\$ 730,564$ & $\$ 1,257,813$ & - & - \\
\hline Toronto C08 & - & $\$ 1,559,333$ & $\$ 815,000$ & $\$ 606,765$ & $\$ 1,330,000$ & - & $\$ 320,000$ \\
\hline Toronto C09 & $\$ 2,550,375$ & $\$ 805,000$ & - & $\$ 1,033,750$ & - & $\$ 1,198,750$ & $\$ 705,000$ \\
\hline Toronto C02 & $\$ 1,400,000$ & $\$ 1,145,000$ & $\$ 1,097,000$ & $\$ 1,318,999$ & - & - & - \\
\hline
\end{tabular}

\begin{tabular}{|l|c|l|c|c|}
\hline & Bachelor & $\begin{array}{l}\text { One } \\
\text { Bedroom }\end{array}$ & Two Bedroom & Three Bedroom \\
\hline Toronto W02 & - & $\$ 2,162$ & $\$ 2,887$ & - \\
\hline Toronto C01 & $\$ 1,877$ & $\$ 2,319$ & $\$ 3,312$ & $\$ 4,330$ \\
\hline Toronto C02 & $\$ 1,913$ & $\$ 2,508$ & $\$ 4,063$ & $\$ 5,486$ \\
\hline Toronto C08 & $\$ 1,866$ & $\$ 2,238$ & $\$ 3,111$ & $\$ 4,669$ \\
\hline Toronto C09 & - & $\$ 2,302$ & $\$ 4,141$ & $\$ 4,600$ \\
\hline
\end{tabular}


To determine who can afford what typology within the rent tenure, Figure 34 maps out the 10 income deciles along with the corresponding submarket data for the Ward. The data shows that at 30 per cent income ratio nothing is affordable for any income bracket below the 9th decile, while at 50 per cent income ratio a lot more options are affordable above the 5 th decile.

Figure 34: Affordable Rental Typologies by Submarket as Recorded by TREB Market Watch 2018 at $30 \%, 50 \%$ and $70 \%$ of Average Ward 11 Income and Average Millennial Income.

Sources: Author's calculation of affordable income using $30 \%, 50 \%$ and $70 \%$ of Ward 11 average income, divided by 12 for monthly rent payment

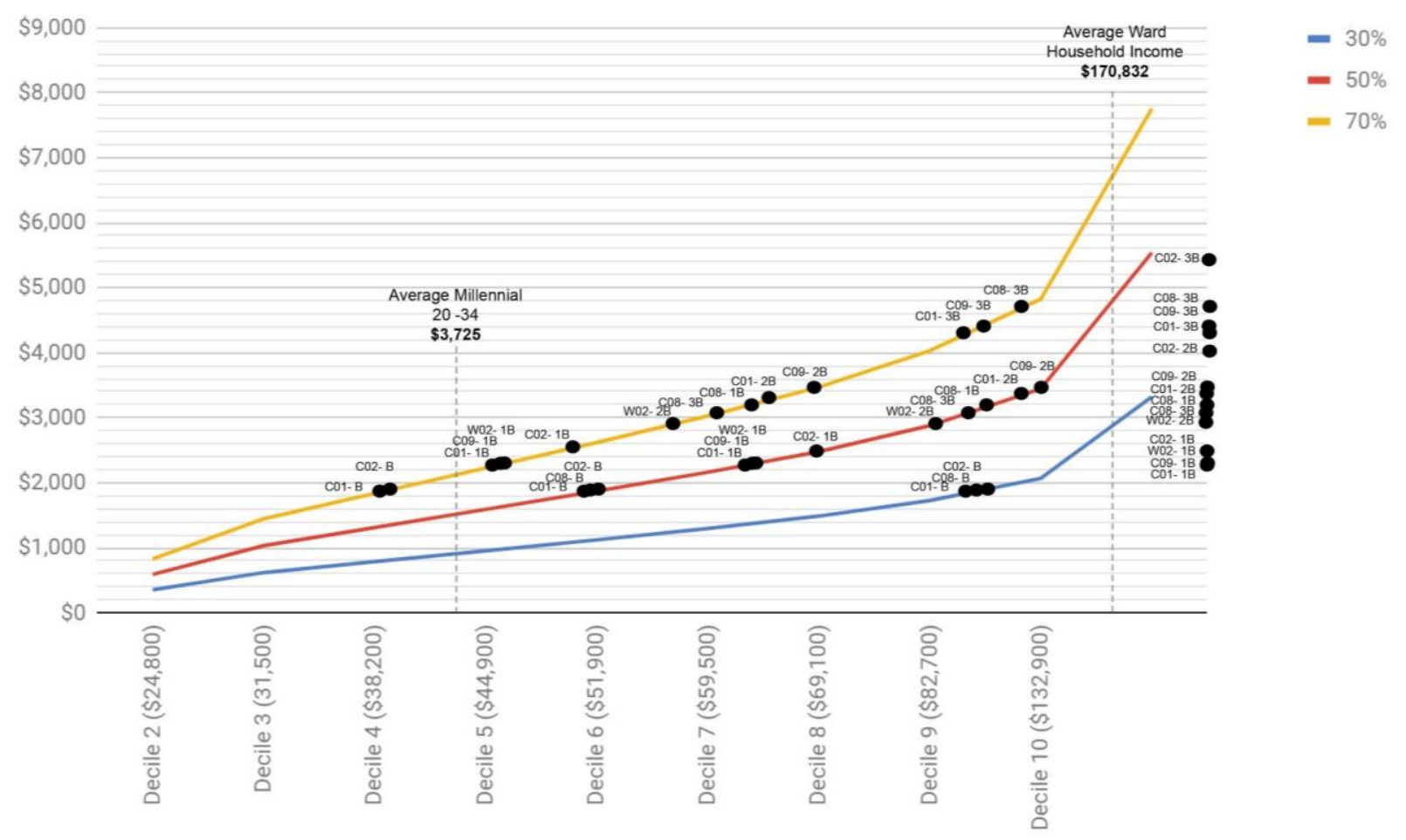

\subsection{3(D) WARD NEW HOUSING SUPPLY ANALYSIS}

Majority of this Ward is within the boundaries of the Rosedale-Moore Park (98), Annex (95) and portions of Bay Street Corridor (76) and Church - Yonge Corridor (75) .According to CMHC's under construction inventory by dwelling type for 2018, a total supply of 6,842 units are under construction (Canada Mortgage and Housing Corporation, 2019). Table 13 demonstrates the breakdown results for new supply within the neighbourhoods; 
Table 13: New Housing under Construction Inventory by Dwelling Type by Neighbourhood 2018 Sources: Canada Mortgage and Housing Corporation (CMHC) Housing Market Information Portal.

\begin{tabular}{|l|c|c|c|c|c|}
\hline Neighbourhood & Single & Semi detached & Row & Apartment & Total \\
\hline Rosedale & 4 & 0 & 0 & 0 & 4 \\
\hline Moore Park & 3 & 0 & 0 & 82 & 85 \\
\hline Annex & 1 & 0 & 0 & 1,248 & 1,249 \\
\hline Bay Corridor & 0 & 0 & 0 & 174 & 174 \\
\hline Church Yonge & 1 & 0 & 0 & 5,330 & 5,330 \\
\hline Total & 9 & 0 & 0 & 6,834 & 6,842 \\
\hline
\end{tabular}

Based on the above data, the only available choices of new housing typology for the Ward population are apartments, with only 9 units of single detached units. Thus making it very difficult for millennials to choose a tenure that suits their needs at affordable prices.

\subsubsection{WARD 13 - TORONTO CENTRE}

Ward 13 is also located in the heart of downtown Toronto and covers a number of important areas within the city including; Regent Park, St. James Town, Cabbagetown, Church and Wellesley, Ryerson University, Toronto Eaton Centre and a portion of the City's Financial district. Its boundaries stretch to Bay Street, College Street, Yonge Street and Dundas Street on the west, the Don River to the east and the Esplanade on the south. To the North border ate Rosedale Valley Road, Bloor Street East, Mount Pleasant Road and Charles Street. Layering Ward 13 boundary on top of the TREB submarket boundaries, submarkets C08, and a small portion of highlighted with a black outline highlighted with a black outline on are their boundaries on Figure 35 and in Appendix $\mathrm{G}$ and $\mathrm{H}$. These submarkets make up the relative markets to which affordability should be compared. 
Figure 35: Ward13 Profile with Overlaid TREB Submarket Boundary Sources: City of Toronto Ward 13 Profile and TREB Submarket boundaries

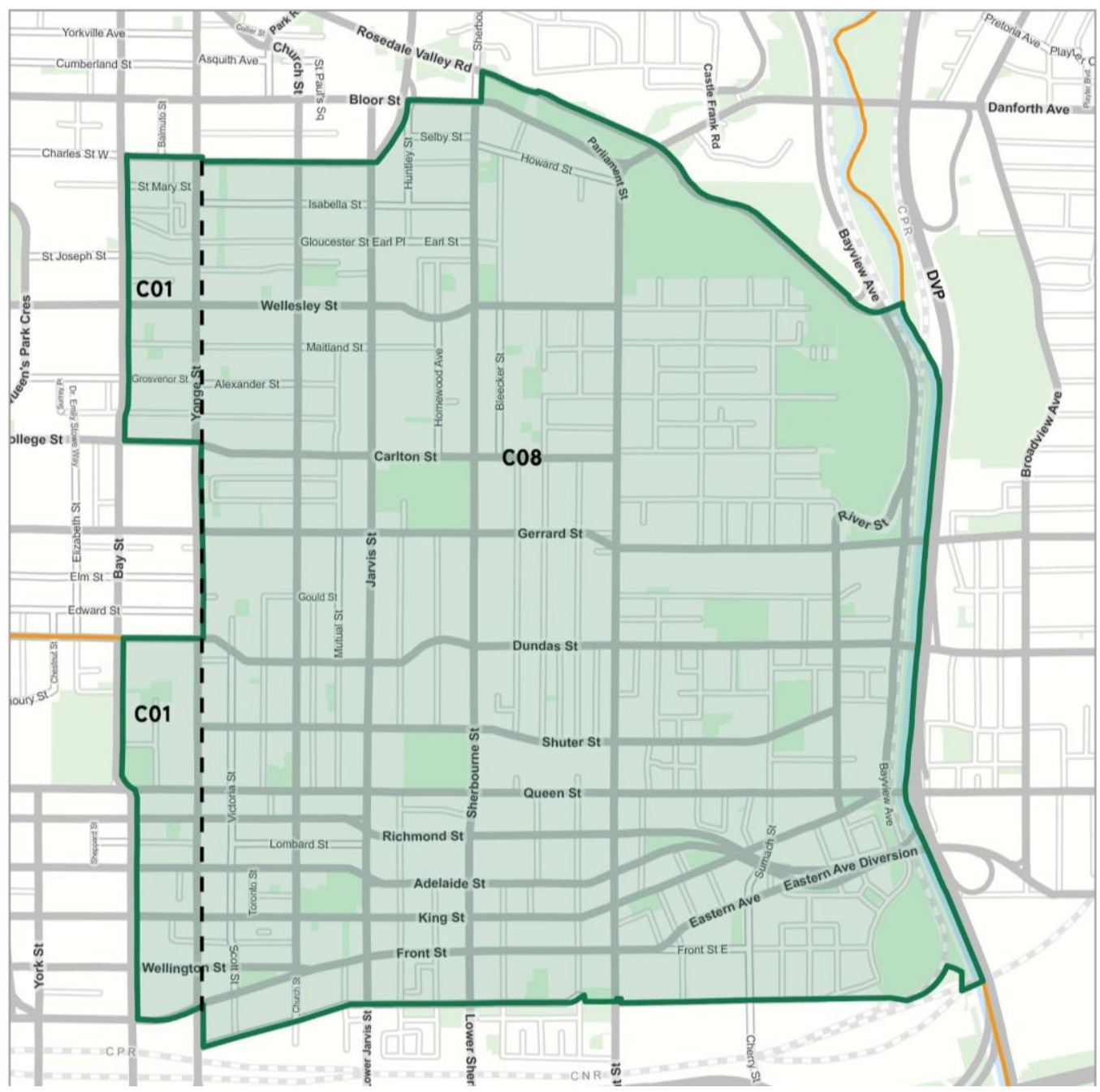

\subsection{4(A) OWNERSHIP ANALYSIS}

At an average household income of $\$ 75,382$, the maximum affordable purchase price of $\$ 337,900$ assuming a 10 percent down payment and $5.34 \%$ interest rate over 25 year amortization period. Highlighted in red in Appendix $G$ are the submarket locations and tenure at which households can purchase units that would be considered affordable.

To demonstrate this geographically, Figure 36 shows the distribution of housing typology as deemed affordable by the maximum calculated purchase price. Submarkets that are in yellow demonstrate an affordability of condominium apartments, areas with yellow and diagonal hatching show affordability of both condominium apartments and Condominium towns. Green is 
used to represent areas with affordable co-apartments and red is representative of areas with affordable co-ownership apartments.

Figure 36: Affordable Typologies at Average Ward 13 Income by Submarket as Recorded by TREB Market Watch 2018.

Sources: Author's calculation of affordable income using 30\% of Ward 13 average income, 10 percent down payment and $5.34 \%$ interest rate over a 25 -year amortization period.

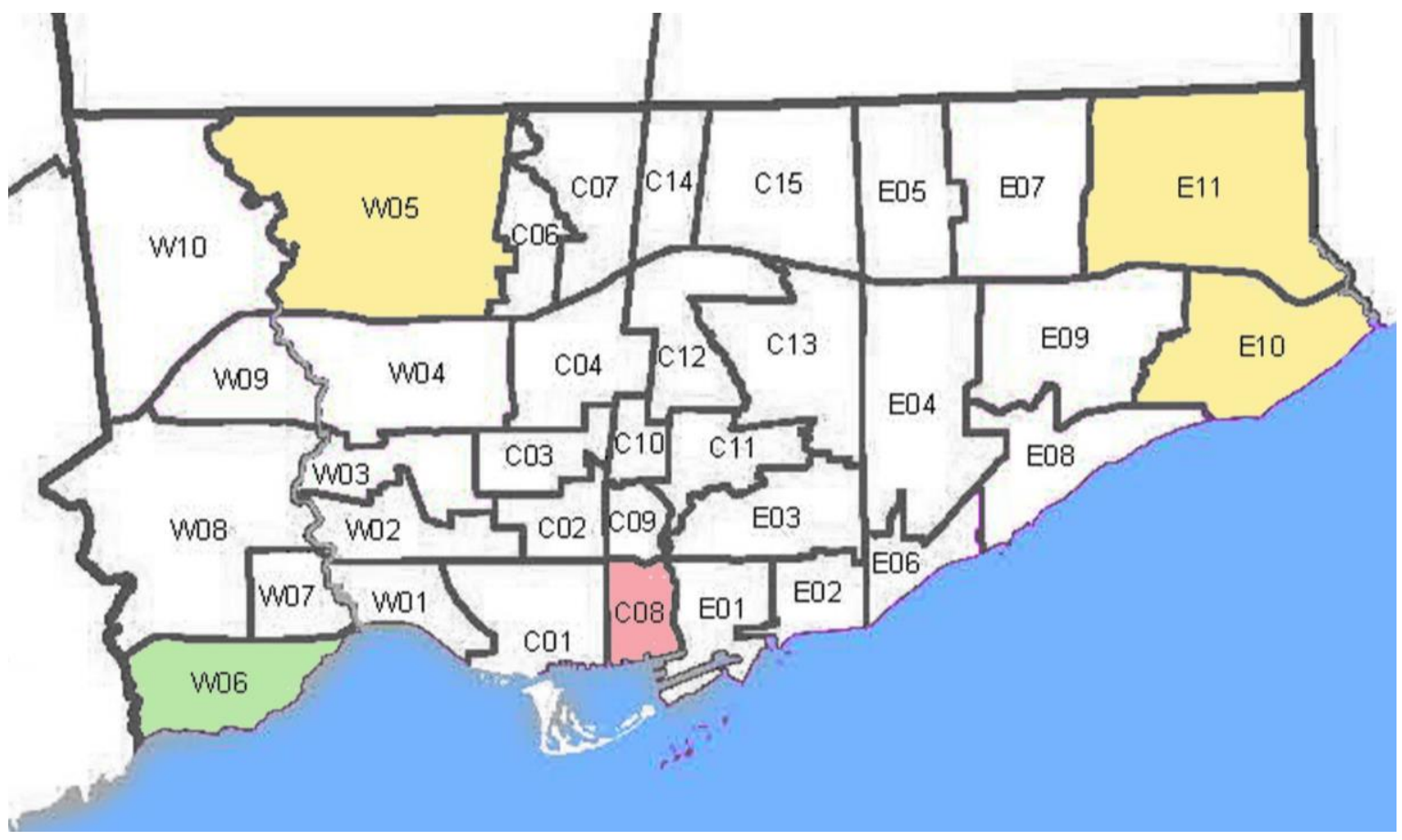

\begin{tabular}{|c|c|c|c|c|c|c|c|}
\hline Colour & Detached & Semi-detached & Condo Town & \begin{tabular}{|l|} 
Condo \\
Apartment
\end{tabular} & $\begin{array}{l}\text { Row/Town- } \\
\text { house }\end{array}$ & Co-apartment & $\begin{array}{l}\text { Co-owner } \\
\text { apartment }\end{array}$ \\
\hline & & & & $\mathbf{x}$ & & & \\
\hline $\mathrm{WW}$ & & & $x$ & $x$ & & & \\
\hline & & & & & & & $x$ \\
\hline & & & $x$ & $x$ & $x$ & & \\
\hline & & $x$ & $x$ & $x$ & $x$ & & \\
\hline & $x$ & & $x$ & $x$ & & & \\
\hline & & & & $x$ & $x$ & & \\
\hline & & & & $x$ & & & $x$ \\
\hline & $x$ & $x$ & $x$ & $x$ & & & \\
\hline & $x$ & & $x$ & $x$ & & & \\
\hline & $x$ & $x$ & $x$ & $x$ & $x$ & & \\
\hline
\end{tabular}


Figure 36 demonstrates that there are opportunities in the east, less the west and least of all within the central corridor of the City for affordable condominium apartments at the assumed average household income of Ward 13 at $\$ 75,382$. By comparing the average Ward income and the associated submarket, only co-ownership apartments presented at market rate are affordable to a household earning the average income at 30 per cent ratio, which could result in overspending or by exploring the rental model.

\subsection{4(B) RENTAL ANALYSIS}

In terms of the rental tenure, the maximum affordable rent is $\$ 1,885$ per month, assuming 30 per cent ration of income divided by 12 to determine affordable monthly rent payment. Appendix H shows rental data is based on TREB Q4 2018 rental market watch, where the affordable housing typology is highlighted in red. Submarkets that are associated with the Ward boundaries are marked in black outline.

As demonstrated in Appendix $\mathrm{H}$, based on 30 per cent of the average Ward household income, the 1 Bedroom tenure is affordable within the entire City. Based on the submarket analysis, C08 which is representative of the entire submarket for this Ward, only bachelor unit typology is affordable.

To demonstrate this geographically, Figure 37 shows the distribution of housing typology as deemed affordable by the above table analysis. Submarkets that are in purple demonstrate an affordability of 1 Bedrooms only, areas with yellow show affordability of both 1 Bedroom and bachelor units. Areas combining affordability of 1 Bedroom +Bachelor and 2 Bedrooms are in orange, 1 Bedroom + 2 Bedrooms are in green, 1 Bedroom +2 Bedroom +3 Bedroom are in red, 1 Bedroom+ Bachelor + 3 Bedroom are in blue, 1 Bedroom+3 Bedroom are in pink, and finally those coloured white are unaffordable and those with no data are in grey. 
Figure 37: Affordable Typologies at Average Ward 13 Income by Submarket as Recorded by TREB Market Watch 2018.

Sources: Author's calculation of affordable income using $30 \%$ of Ward 13 average income, divided by 12 for monthly rent payment

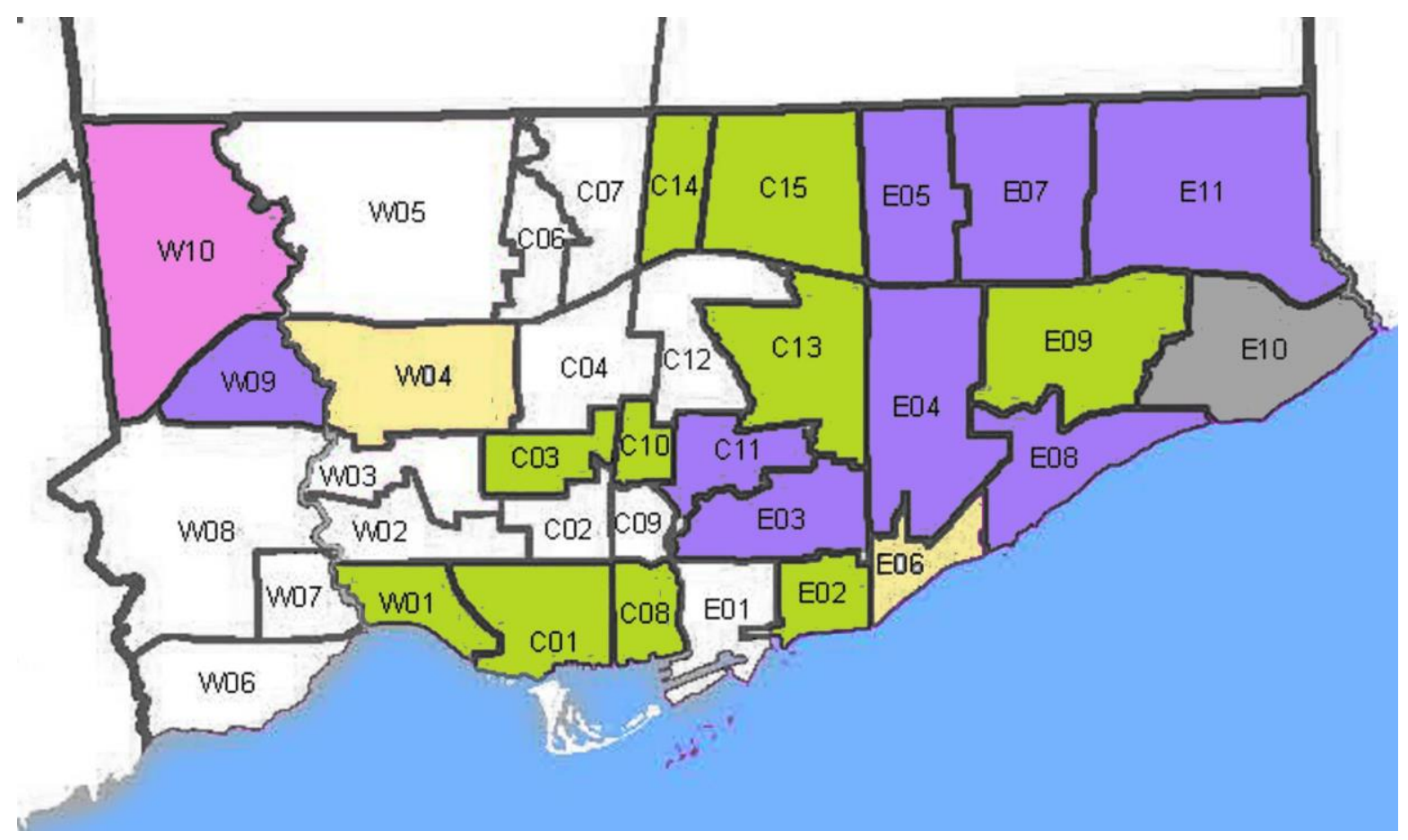

\begin{tabular}{|c|c|c|c|c|}
\hline Colour & Bachelor & 1 Bedroom & 2 Bedroom & 3 Bedroom \\
\hline \hline & $\mathbf{X}$ & & & \\
\hline \hline & $\mathbf{X}$ & $\mathbf{X}$ & & \\
\hline \hline & & $\mathbf{X}$ & & \\
\hline \hline & $\mathbf{X}$ & $\mathbf{X}$ & $\mathbf{X}$ & \\
\hline \hline & & $\mathbf{X}$ & $\mathbf{X}$ & \\
\hline \hline & & $\mathbf{X}$ & $\mathbf{X}$ & $\mathbf{X}$ \\
\hline \hline & $\mathbf{X}$ & $\mathbf{X}$ & & $\mathbf{X}$ \\
\hline \hline & & $\mathbf{X}$ & & $\mathbf{X}$ \\
\hline \hline & & & & \\
\hline
\end{tabular}


Figure 37 shows that there are plenty of opportunities in the central portion for 1 Bedroom options while variety of 1 Bedroom + Bachelor +2 Bedrooms or 1 Bedroom +2 Bedrooms +3 Bedrooms is seen more towards the east, at the assumed average household income of Ward 13 at $\$ 75,382$.

\subsection{4(C) INCOME RATIO ANALYSIS}

Analysis of both the ownership and rental tenure within the Ward demonstrates that at the average Ward income it is likely that most residents living within this geographic area can afford to rent but very unlikely to afford purchasing a house at an affordable ratio as demonstrated by Table 14.

Table 14: Affordable Typologies by Submarket as Recorded by TREB Market Watch 2018 at $30 \%, 50 \%$ and $70 \%$ of Average Ward 13 Income Sources: Author's calculation of affordable income using $30 \%, 50 \%$ and $70 \%$ of Ward 13 average income, assuming 10 percent down payment and $5.34 \%$ interest rate at a 25 -year amortization period for ownership, while dividing the income by 12 for affordable monthly rent payment.

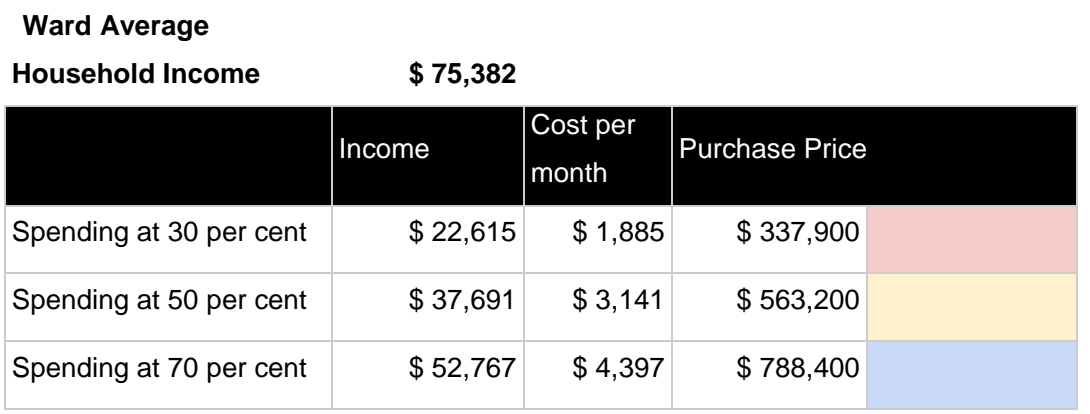

\begin{tabular}{|l|r|r|r|r|r|l|l|}
\hline & Detached & $\begin{array}{l}\text { Semi } \\
\text { detached }\end{array}$ & $\begin{array}{l}\text { Condominiu } \\
\mathbf{m} \\
\text { Townhouse }\end{array}$ & $\begin{array}{l}\text { Condominium } \\
\text { apartment }\end{array}$ & $\begin{array}{l}\text { Row/Town } \\
\text { house }\end{array}$ & Co-apartment & $\begin{array}{l}\text { Co- } \\
\text { ownership } \\
\text { apartment }\end{array}$ \\
\hline Toronto C01 & $\$ 1,975,296$ & $\$ 1,340,600$ & $\$ 969,663$ & $\$ 730,564$ & $\$ 1,257,813-$ & - \\
\hline Toronto C08 & - & $\$ 1,559,333$ & $\$ 815,000$ & $\$ 606,765$ & $\$ 1,330,000-$ & $\$ 320,000$ \\
\hline
\end{tabular}

\begin{tabular}{|l|c|l|r|r|}
\hline & Bachelor & $\begin{array}{l}\text { One } \\
\text { Bedroom }\end{array}$ & $\begin{array}{l}\text { Two } \\
\text { Bedroom }\end{array}$ & $\begin{array}{l}\text { Three } \\
\text { Bedroom }\end{array}$ \\
\hline Toronto C01 & $\$ 1,877$ & $\$ 2,319$ & $\$ 3,312$ & $\$ 4,330$ \\
\hline Toronto C08 & $\$ 1,866$ & $\$ 2,238$ & $\$ 3,111$ & $\$ 4,669$ \\
\hline
\end{tabular}

To determine who can afford what typology within the rent tenure, Figure 38 shows the 10 income deciles along with the corresponding submarket data for the ward. The data shows that at $30 \%$ income ratio nothing is affordable for any income bracket below the 9th decile, while at 50 per cent income ratio a lot more options are affordable above the 5th decile. 
Figure 38: Affordable Rental Typologies by Submarket as Recorded by TREB Market Watch 2018 at $30 \%, 50 \%$ and $70 \%$ of Average Ward 13 Income and Average Millennial Income.

Sources: Author's calculation of affordable income using $30 \%, 50 \%$ and $70 \%$ of Ward 13 average income, divided by 12 for monthly rent payment

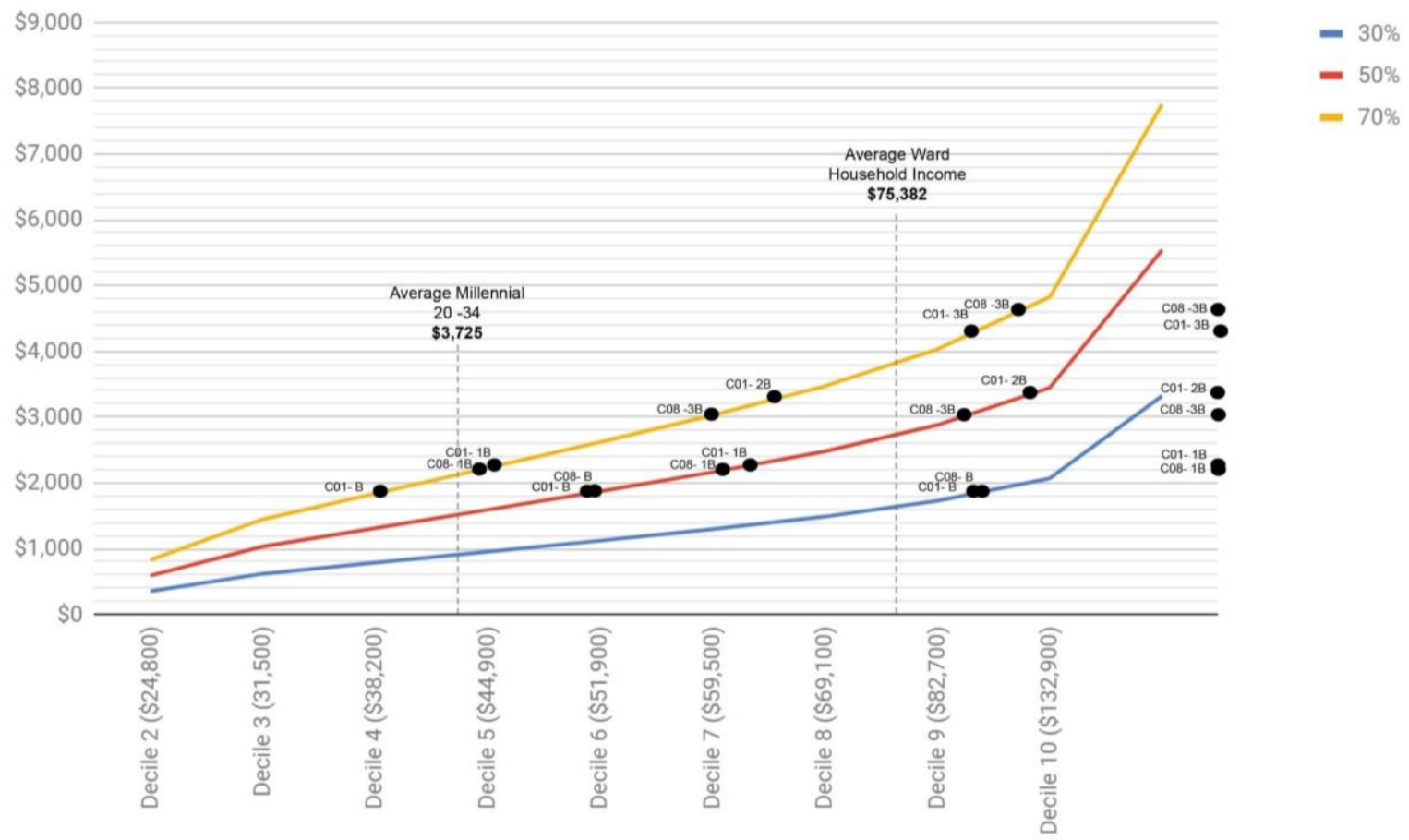

\subsection{3(D) WARD NEW HOUSING SUPPLY ANALYSIS}

Majority of this Ward is within the boundaries of the Cabbage South St James Town (71), Regent Park (72), Moss Park (73), North St. James Town (74) and portions of Church - Yonge Corridor (75). According to CMHC's under construction inventory by dwelling type for 2018, a total supply of 11,261 units are under construction (Canada Mortgage and Housing Corporation, 2019). Table 15 demonstrates the breakdown results for new supply within the neighbourhoods; 
Table 15: New Housing under Construction Inventory by Dwelling Type by Neighbourhood 2018 Sources: Canada Mortgage and Housing Corporation (CMHC) Housing Market Information Portal.

\begin{tabular}{|l|l|l|l|l|l|}
\hline \multicolumn{2}{|c|}{ Neighbourhood } & Semi detached Row & \multicolumn{1}{l|}{ Apartment } & Total \\
\hline Cabbage South St James Town & 0 & 0 & 0 & 1,011 & 1,011 \\
\hline Regent Park & 0 & 0 & 0 & 3,189 & 3,189 \\
\hline Annex & 1 & 0 & 0 & 1,248 & 1,249 \\
\hline North St. James Town & 1 & 0 & 32 & 449 & 482 \\
\hline Church Yonge & 0 & 0 & 0 & 5,330 & 5,330 \\
\hline Total & 2 & 0 & 32 & 11,227 & 11,261 \\
\hline
\end{tabular}

\subsubsection{WARD 18 - WILLOWDALE}

Although geographically Ward 18 is located all the way in the north and not located anywhere near the downtown core, it has raised significant interest for many millennials. The Ward is currently under the jurisdiction of the elected councillor John Fillion. It is bordered by Highway 401 to the south, Bathurst Street to the West and Bay View Avenue to the East.

Layering Ward 18 boundary on top of the TREB submarket boundaries, submarkets C07 and C14 highlighted with a black outline on Figure 39 and Appendix I and J make up the relative market to which affordability should be compared. By comparing the average Ward income and the associated submarkets, none of the typologies presented at market rate are affordable for purchase to a household earning the average income at 30 per cent ratio, which could result in overspending or by exploring the rental model. 
Figure 39: Ward18 Profile with Overlaid TREB Submarket boundary Sources: City of Toronto Ward 18 Profile and TREB Submarket boundaries

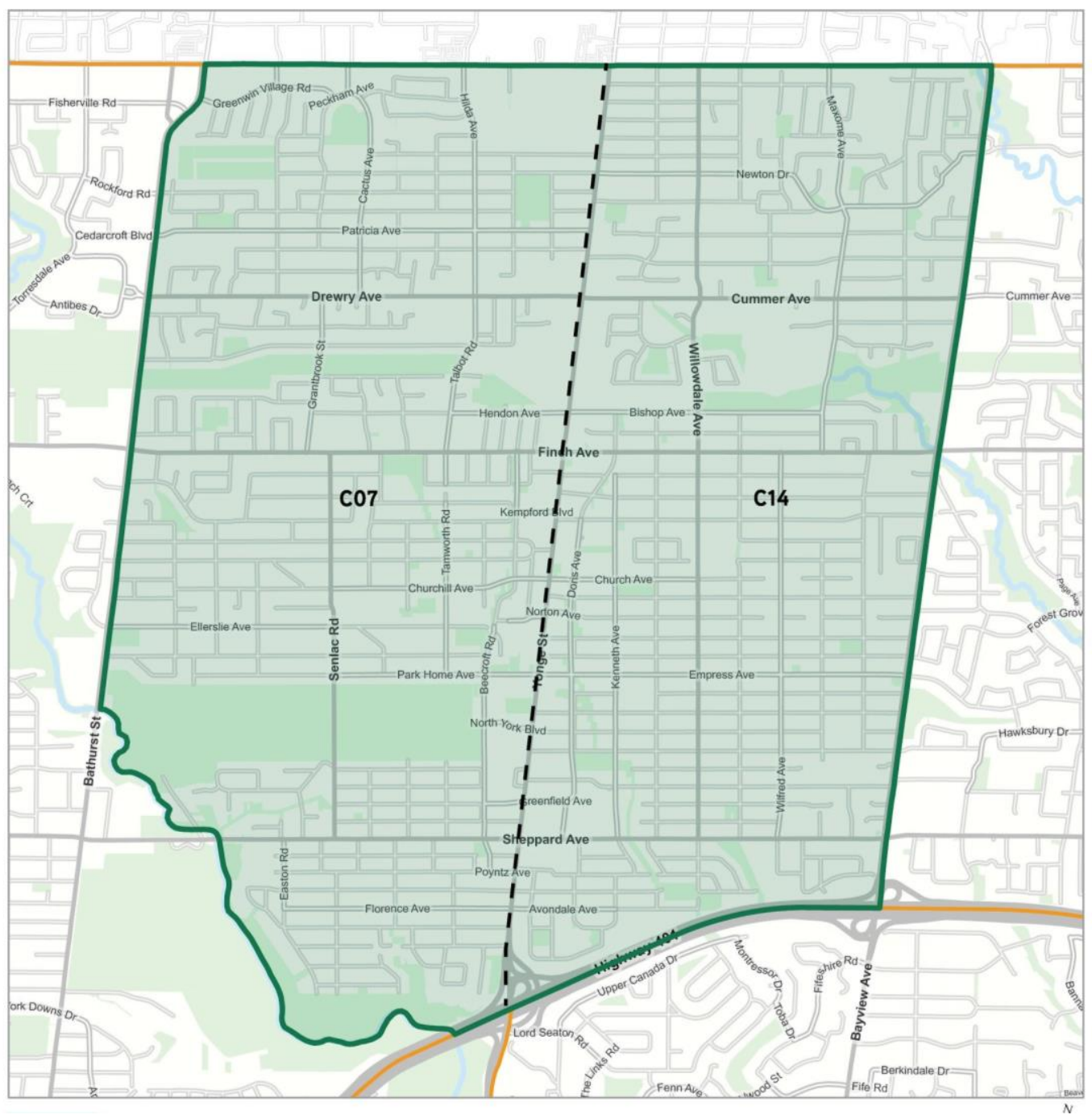

\subsection{5(A) OWNERSHIP ANALYSIS}

At an average household income of $\$ 87,416$, the maximum affordable purchase price of $\$ 91,800$. This purchase price is based on a 30 per cent income ratio at a 25 -year amortization, 10 percent down payment and 5.34 per cent interest rate. Highlighted in red in Appendix I are the submarket locations and tenure at which households can purchase units that would be considered affordable.

To demonstrate this geographically, Figure 40 shows the distribution of housing typology as deemed affordable by the maximum calculated purchase price. Submarkets that are in yellow demonstrate an affordability of condominium apartments, areas with yellow and diagonal hatching show affordability of both condominium apartments and Condominium towns. Green is 
used to represent areas with affordable co-apartments and red is representative of areas with affordable co-ownership apartments.

Figure 40: Affordable Typologies at Average Ward 18 Income by Submarket as Recorded by TREB Market Watch 2018.

Sources: Author's calculation of affordable income using 30\% of Ward 18 average income, 10 percent down payment and $5.34 \%$ interest rate over a 25 -year amortization period.

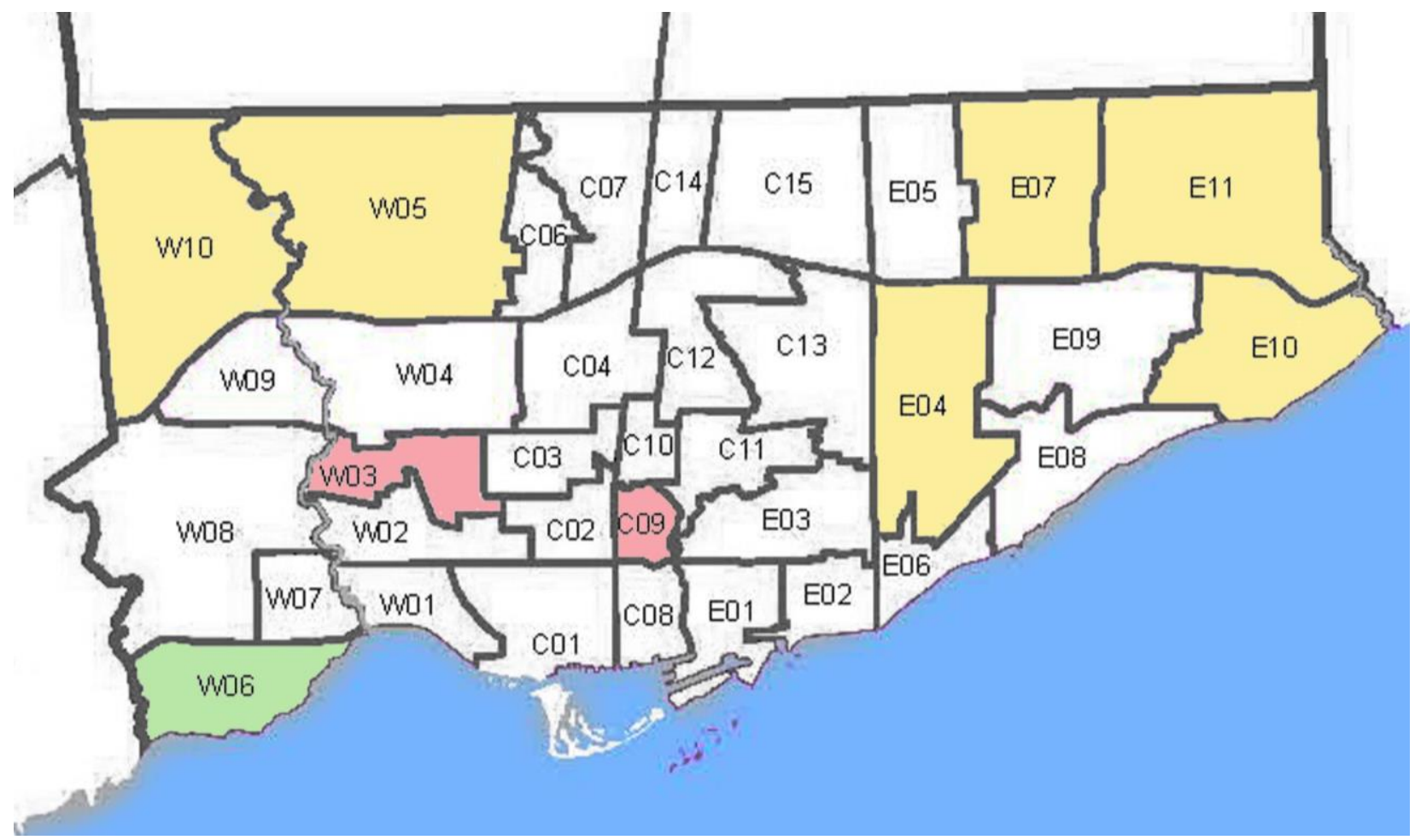

\begin{tabular}{|c|c|c|c|c|c|c|c|}
\hline Colour & Detached & Semi-detached & Condo Town & $\begin{array}{l}\text { Condo } \\
\text { Apartment }\end{array}$ & $\begin{array}{l}\text { Row/Town- } \\
\text { house }\end{array}$ & Co-apartment & $\begin{array}{l}\text { Co-owner } \\
\text { apartment }\end{array}$ \\
\hline & & & & $x$ & & & \\
\hline 11111 & & & $x$ & $x$ & & & \\
\hline & & & & & & & $x$ \\
\hline & & & $x$ & $x$ & $x$ & & \\
\hline & & $x$ & $x$ & $x$ & $x$ & & \\
\hline & $x$ & & $x$ & $x$ & & & \\
\hline & & & & $x$ & $x$ & & \\
\hline & & & & $x$ & & & $x$ \\
\hline & $\mathbf{x}$ & $x$ & $x$ & $x$ & & & \\
\hline & $x$ & & $x$ & $x$ & & & \\
\hline & $x$ & $x$ & $x$ & $x$ & $x$ & & \\
\hline
\end{tabular}


Figure 40 shows that there are opportunities in the east, less the west and least of all within the central corridor of the City for affordable condominium apartments at the assumed average household income of Ward 18 at $\$ 87,416$.

By comparing the average Ward income and the associated submarkets, none of the typologies presented at market rate are affordable for purchase to a household earning the average income at 30 per cent ratio, which could result in overspending or by exploring the rental model.

\subsection{5(B) RENTAL ANALYSIS}

In terms of the rental tenure, the maximum affordable rent is $\$ 2,185$ per month, assuming 30 per cent ration of income divided by 12 to determine affordable monthly rent payment. Appendix J shows rental data is based on TREB Q4 2018 rental market watch, where the affordable housing typology is highlighted in red. Submarkets that are associated with the Ward boundaries are marked in black outline.

Appendix $\mathrm{J}$ demonstrates that based on 30 per cent of the average Ward household income, the one Bedroom tenure is affordable within the entire City. Based on the submarket analysis, C07 and C14 are representative of the applicable submarkets for this Ward, the bachelor and one Bedroom unit typology is affordable.

To demonstrate this geographically, Figure 41 shows the distribution of housing typology as deemed affordable by the above table analysis. Submarkets that are in purple demonstrate an affordability of 1 Bedrooms only, areas with yellow show affordability of both 1 Bedroom and bachelor units. Areas combining affordability of 1 Bedroom +Bachelor and 2 Bedrooms are in orange, 1 Bedroom + 2 Bedrooms are in green, 1 Bedroom + 2 Bedroom +3 Bedroom are in red, 1 Bedroom+ Bachelor +3 Bedroom are in blue, 1 Bedroom+3 Bedroom are in pink, and finally those coloured white are unaffordable and those with no data are in grey. 
Figure 41: Affordable Typologies at Average Ward 18 Income by Submarket as Recorded by TREB Market Watch 2018.

Sources: Author's calculation of affordable income using $30 \%$ of Ward 18 average income, divided by 12 for monthly rent payment

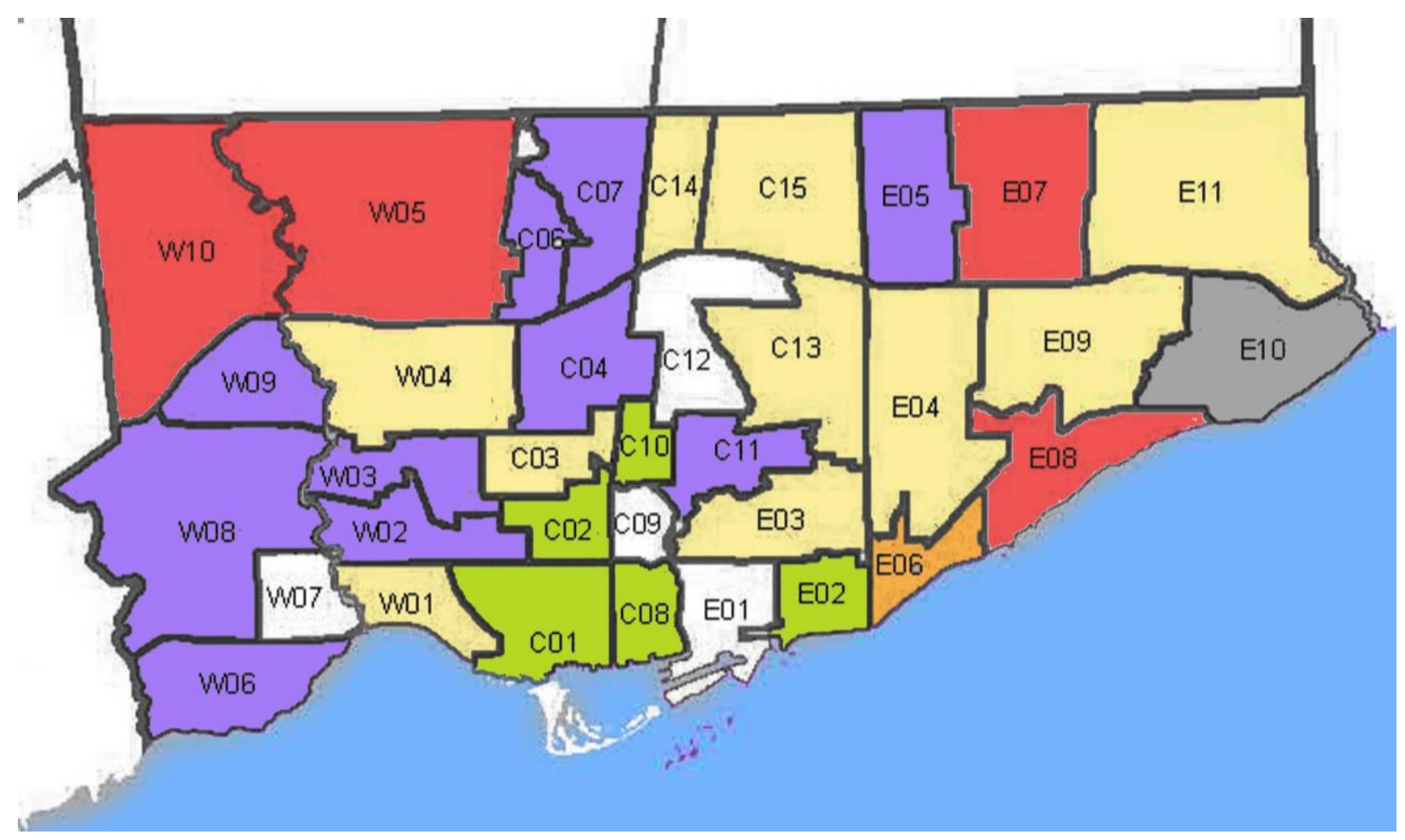

\begin{tabular}{|c|c|c|c|c|}
\hline Colour & Bachelor & 1 Bedroom & 2 Bedroom & 3 Bedroom \\
\hline & $x$ & & & \\
\hline & $\mathbf{X}$ & $x$ & & \\
\hline & & $x$ & & \\
\hline & $\mathbf{x}$ & $x$ & $x$ & \\
\hline & & $x$ & $\mathbf{x}$ & \\
\hline & & $x$ & $x$ & $x$ \\
\hline & $x$ & $x$ & & $\mathbf{x}$ \\
\hline & & $\mathbf{X}$ & & $\mathbf{x}$ \\
\hline & & & & \\
\hline
\end{tabular}

Figure 41 shows that there seems to be a division between the east and west of the city where the west offers more opportunities of bachelor and 1 Bedroom unit, while the west offers only 1 Bedroom. Overall analysis shows that at the average Ward income of $\$ 87,416$, there are plenty 
of opportunities for bachelor units in the south central and more 1 Bedroom options as it moves outward.

\subsection{5(C) INCOME RATIO ANALYSIS}

Analysis of both the ownership and rental tenure within the Ward demonstrates that at the average Ward income it is likely that most residents living within this geographic area can afford to rent but very unlikely to afford purchasing a house at an affordable ratio of 30 per cent.

Table 16 compares both ownership and rental tenures at a spending ratio of 30 per cent, 50 per cent and 70 per cent of the average Ward income to determine affordability within the applicable submarkets. At 50 per cent most of the rental typologies are affordable, while for ownership tenure only a few is affordable at 70 per cent spending ratio of income.

Table 16: Affordable Typologies by Submarket as Recorded by TREB Market Watch 2018 at $30 \%, 50 \%$ and $70 \%$ of Average Ward 18 Income

Sources: Author's calculation of affordable income using $30 \%, 50 \%$ and $70 \%$ of Ward 18 average income, assuming 10 percent down payment and $5.34 \%$ interest rate at a 25 -year amortization period for ownership, while dividing the income by 12 for affordable monthly rent payment.

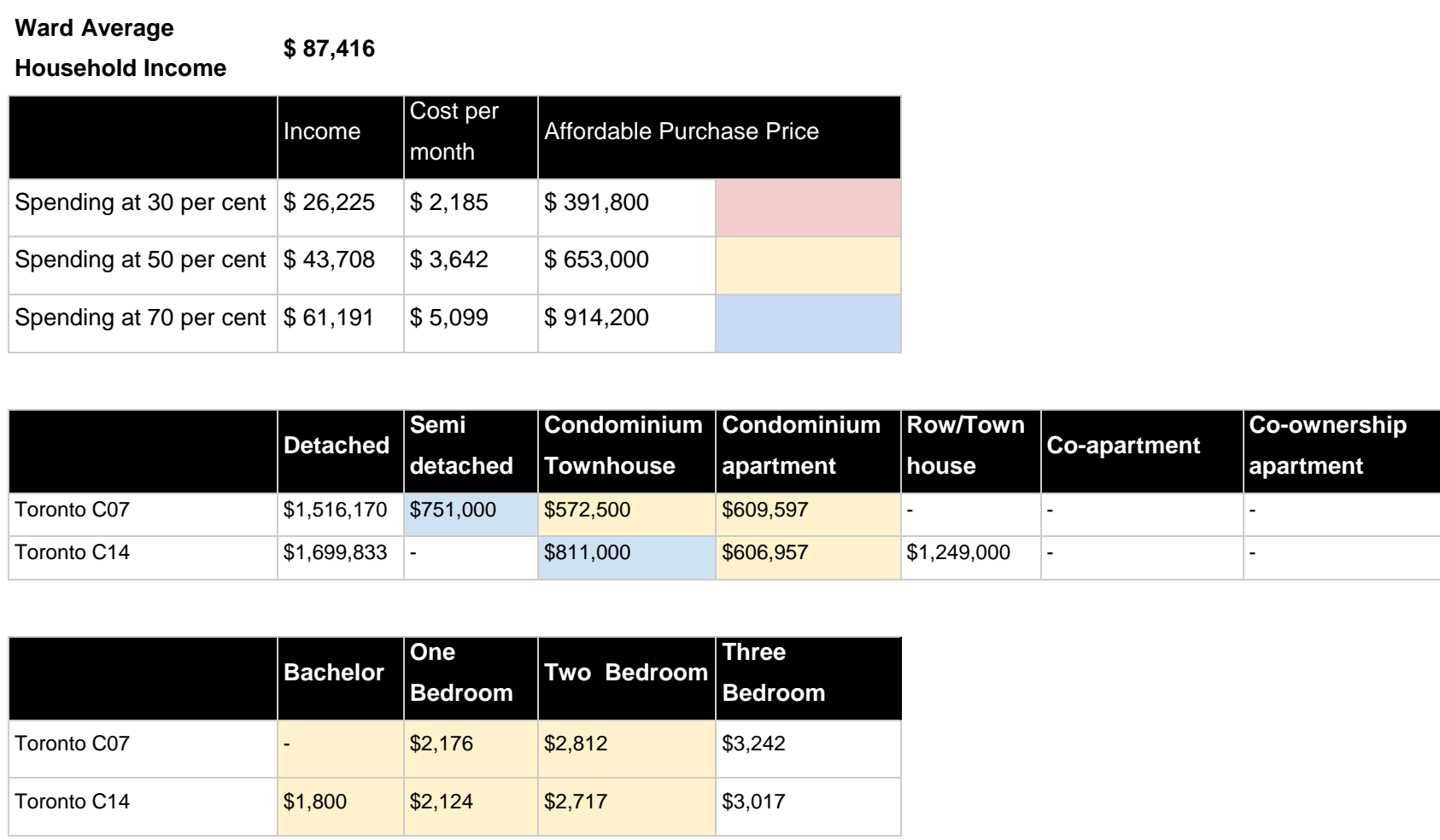

To determine who can afford what typology within the rent tenure, Figure 42 maps out the 10 income deciles along with the corresponding submarket data for the Ward. The data shows that at 30 per cent income ratio nothing is affordable for any income bracket below the 9th decile, while at 50 per cent income ratio a lot more options are affordable above the 5 th decile. 
Figure 42: Affordable Rental Typologies by Submarket as Recorded by TREB Market Watch 2018 at $30 \%, 50 \%$ and $70 \%$ of average Ward 18 Income and Average Millennial Income.

Sources: Author's calculation of affordable income using $30 \%, 50 \%$ and $70 \%$ of Ward 18 average income, divided by 12 for monthly rent payment.

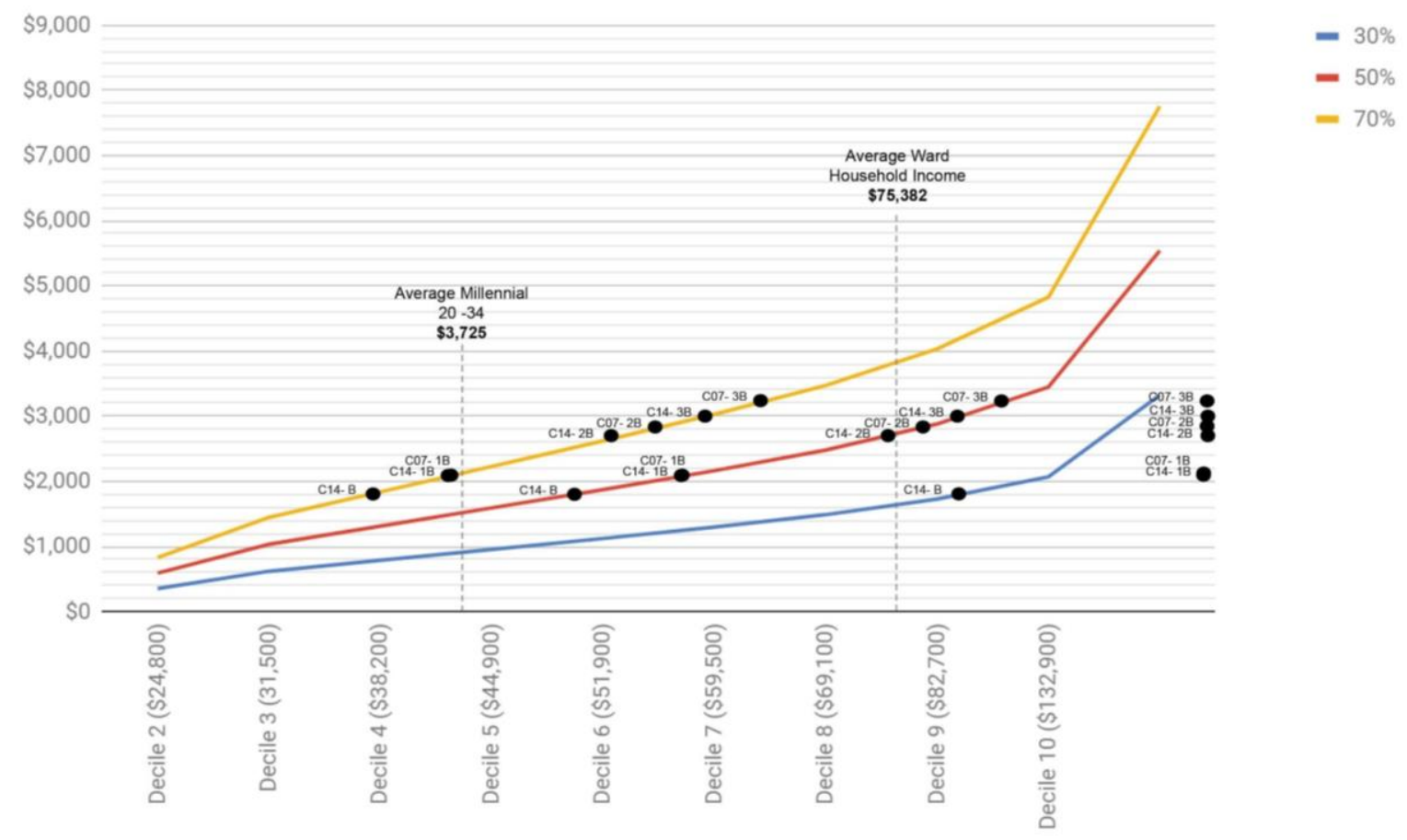

\subsection{5(D) WARD NEW HOUSING SUPPLY}

Majority of this Ward is within the boundaries of the Newtonbrook West (36), Willowdale West (37), Lansing-Westgate (38), Newtonbrook East (50) and Willowdale East (51). According to CMHC's under construction inventory by dwelling type for 2018 , a total supply of 1,573 units are under construction. Table 17 demonstrates the breakdown results for new supply within the neighbourhoods; 
Table 17: New Housing under Construction Inventory by Dwelling Type by Neighbourhood 2018. Sources: Canada Mortgage and Housing Corporation (CMHC) Housing Market Information Portal.

\begin{tabular}{|l|l|l|l|l|l|l|}
\hline Neighbourhood & Single Semi detached & Row & Apartment & Total \\
\hline $\begin{array}{l}\text { Newtonbrook West/ } \\
\text { Willowdale West }\end{array}$ & 84 & 0 & 0 & 741 & 825 \\
\hline Lansing-Westgate & 54 & 0 & 0 & 0 & 54 \\
\hline $\begin{array}{l}\text { Newtonbrook East/ } \\
\text { Willowdale East }\end{array}$ & 87 & 0 & 5 & 602 & 694 \\
\hline Total & 225 & 0 & 5 & 1,343 & 1,573 \\
\hline
\end{tabular}

Based all data from Table 17, unlike the Wards 9,10,11 and 13, Ward 18 offers more supply on the detached dwelling typology along with apartments, and only 5 units of row units. Although this Ward offers more options for the Ward population, the detached dwellings are highly priced at market price that may make it unaffordable for some millennials.

\section{CONCLUSION}

In general, analysis of Wards 9,10,11,13 and 18 demonstrated that based on household income it seems that most of the ward populations can afford to rent bachelor and 1 bedroom tenures. In other words if families were to live in these wards, their household income would have to be much higher or their spending to income ratio would have to be significantly higher to be able to afford a tenure that can accommodate them. As demonstrated in the analysis, at $50 \%$ of income ration starting at the $8^{\text {th }}$ decile households are beginning to have option from which they can choose to rent. However having an income lower than that, the current market does not support in terms of housing pricing and they will be forced to look for City allocated affordable housing Units as qualified. With low new construction stock, and high resale price in the market, millennials don't stand a chance of access to affordable housing within a competitive market. Therefore there is a need to provide affordable housing for millennials, in order to so the market needs to respond by new housing supply by product type. This raises the question of if households can barely afford to rent or purchase in the resale market, can they afford anything that is new construction? Acknowledging that new construction holds a premium over existing stock, is new construction the new millennial dream that has become so unaffordable? Can Planning Policy fix this situation? and How? 


\section{RECOMMENDATIONS - PLANNING POLICY}

With the crisis at hand of limited supply and high demand making housing unaffordable for millennials within the City, from a planning policy framework, what can be done?. In order to answer this question, it is important to understand and consider the reasons and possibilities behind this gap, realizing that when supply within the resale market is limited, potential purchasers will turn to the new housing market to meet their housing needs. This section identifies the important provincial and municipal policies that affect affordability in the City of Toronto.

\subsection{REDEFINING THE TERM 'AFFORDABILITY’ TO REFLECT MARKET CONDITIONS AND CONSISTENCY AMONG POLICIES}

The Planning Act (1990) is the provincial legislation intended to set ground rules and policies for a land use planning system in Ontario. The role of the province as set out in the Planning Act is to among other roles' to give advice to municipalities and the public on land use planning issues. The purpose of the act is to maintain and integrate provincial interest in provincial and municipal interest, which includes provisions of a full range of housing, including affordable housing.

Section 3 of the Planning Act authorizes the Minster or the minster together with any other minister of the Crown to issue a Provincial Policy Statement (PPS) from time to time on matters relating to municipal planning, that in the opinion of the Minister are of provincial interest. Under Part IV: Vision for Ontario's Land Use Planning System of the PPS, affordable housing is listed as a form of housing that is used to promote a mix of land uses and efficient development patterns. Housing policies in the PPS require authorities to provide for an appropriate range and mix of housing types and densities required to meet projected requirements of current and future residents of the regional market area by establishing and implementing minimum targets for housing that is affordable to low and moderate income households. According to the housing policy, authorities shall " maintain at all times the ability to accommodate residential growth for a minimum of 10 years and maintain at all times where new development is to occur, land with servicing capacity sufficient to provide at least a three-year supply of residential units available through lands suitably zoned to facilitate residential intensification and redevelopment, and land in draft approved and registered plans" (Ministry of Municipal Affairs and Housing, 2014). Using the PPS as a guiding policy, municipalities such as the City of Toronto are obliged to meet the 
targets set out for the province regarding providing a mix of housing types and enough supply to meet the market demand.

The PPS also defines affordable housing using the 30 per cent, which as demonstrated in the analysis above does not represent the reality of the market in relation to the City of Toronto. This does not mean that this ratio is not well represented of other markets in other parts of Canada. As such understanding that planning policy operates in a hierarchical system, it is recommended that such ratios be revised prior to the release of new PPS to reflect the reality of the markets in place. Flexibility to ratio implementation by geographical area may also be explored by regional market area. Hence the definition of affordable may read as follows for both ownership and rental tenure;

housing for which the purchase price results in annual accommodation costs which do not exceed the percentage set out by the regional or municipal market area of gross annual household income for low and moderate income households

By doing so, areas like City of Toronto that have chance at setting up their own standard of affordability, will be able to determine and develop aid strategies households that realistically cannot afford based on current market rates. It will also encourage individual municipalities to develop creative strategic plans and policies with set targets that can be evaluated against to address local issues of home affordability. Acknowledging that CMHC has a First Home Buyers tax Credit program in place, option to address this is to customize the aid of first home buyers with the down payment through grant support from all levels of government. The down payment is typically one of the largest barrier and challenge for most home buyers. Such customized aid would help make housing affordable for first home buyers by bridging the gap between their needs and the current market affordability rate.

\subsection{ADDRESSING SHORTAGE OF SERVICED LAND TO INCREASE HOUSING SUPPLY IN THE SHORT TERM}

Policy 1.4.1 of the PPS speaks to providing an appropriate range of and mix of housing types and densities required to meet projected requirements of current and future residents of the regional market area, where planning authorities shall (Ministry of Municipal Affairs and Housing, 2014):

a) maintain at all times the ability to accommodate residential growth for a minimum of 10 years through residential intensification and redevelopment and, if necessary, 
lands which are designated and available for residential development; and

b) maintain at all times where new development is to occur, land with servicing capacity sufficient to provide at least a three-year supply of residential units available through lands suitably zoned to facilitate residential intensification and redevelopment, and land in draft approved and registered plans.

As such municipalities must be held accountable to comply with policies of the PPS to maintaining a stock of serviced land for three years for redevelopment. Considering the current rate of stock is not sufficient to meet the demand, a revision of the policy to increase the number of supply years to five is recommended (F. Clayton, Petramala, Researcher, \& Amborski, 2018). The analysis of the supply however should not just be based on having serviced land only but on the type of units based on market demand that will be added as result of this exercise. Identified sites for intensification should be streamlined through the planning process and serviced to incentivize development. Identified greenfield lands on the other hand should have a servicing plan in place that fits within the 5 year capital budget. Action plans should also be set in place in the case of any shortfalls of land supply or housing type (F. Clayton et al., 2018). An action plan for improving housing affordability in the GGH by the Centre of Urban Research and Land Development recommended that 60 days to be given to upper and single tier municipalities to provide the short-term land inventory and 120 days to accommodate long term residential growth for a minimum of 10 years.

\subsection{INTEGRATING LOCAL MARKET DATA AND POLICY DENSITY TARGETS TO ALLOCATE GROWTH BASED ON DEMAND}

Prepared under the Growth Act 2005, the Growth Plan for the Greater Golden Horseshoe (2017) is an initiative by the Ontario government to plan for growth and development within the region. As part of the guiding principles, the plan helps to address the challenge of land development by providing direction on planning for a range and mix of housing options, including second units and affordable housing to serve all sizes, incomes and ages of households to support the achievement of complete communities (Ministry of Municipal Affairs and Housing, 2017).

The Growth Plan also sets minimum density targets for growth within urban growth centres. The City of Toronto has multiple growth centres with a minimum density target of 400 residents and jobs combined per hectare for each of the centres. Density targets are typically based on projected population growth within the region and not based on local market demands. It is 
recommended that growth targets for each centre are flexible in their requirements so that local governments may adjust according to the local housing market demand and economic conditions and land availability. Increasing targets often impacts the economic conditions within municipalities as they have to provide for services to accommodate growth targets without any aid provided to meet those targets. Also the method in which the density targets are calculated to conform known as the land needs analysis needs to be revised to integrate market demand by housing types. This is not a new concept to the planning legislation as the methodology used in the mid 1990's incorporated demand and supply of land by housing typology as part of its methodology for the land needs assessment (F. Clayton et al., 2018).

\subsection{REDEFINING LOCAL (CITY OF TORONTO) PLANNING POLICIES AND PROCEDURES TO ADDRESS SHORTAGE OF SUPPLY}

The City of Toronto' Official Plan (2006) sets out its insight on building the future of the City, one of which is to have affordable housing choices that meet the needs of everyone throughout their lifetime. Conforming to provincial policies the official plan defines affordable housing as housing where the total monthly shelter cost (mortgage principal and interest - based on a 25-year amortization, 10 percent down payment and the chartered bank administered mortgage rate for a conventional 5-year mortgage as reported by the Bank of Canada at the time of application plus property taxes calculated on a monthly basis) equals the average City of Toronto rent, by unit type, as reported annually by the Canada Mortgage and Housing Corporation. Apart from the low AMR rate that does not represent the local market in the City, (recommended to be amended as mentioned earlier in under the PPS section) the definition adds in property taxes as part of the equation. By adding in property taxes as part of affordability, the amount which a household can afford drops making what could be affordable, unaffordable. Hence local policies should be changed and must be coherent with upper tier and provincial policies in the way affordability is defined.

Section 3.2.1 on Housing policies states that "specific policies are needed when a particular kind of housing, whether it be type, tenure or level of affordability, is not sufficiently supplied by the market to meet demand or maintain diversity in the housing stock. Housing gains are needed through new supply and, where new supply is inadequate, existing housing must be maintained" (City of Toronto, 2006).

The plan recognizes that there is a need for affordable low-rise ownership housing for large households with children, affordable rental including purpose built rental. Condominium 
ownership is however listed as an abundant tenure in supply. New housing supply is also encouraged through intensification and infill development in keeping with the plan's policies. In terms of low rise family ownership housing, municipal assistance for is provided for non-profit groups on long term basis such as land at or below market rate fees exemption, etc. To address the shortage of supply of rental housing in the private sector, federal and provincial tax reform as well as municipal incentives such as loans, grants, land at or below market rates, fees and property tax exemptions, rent supplement, etc.is encourage by the plan. The housing policies also aim at preserving the existing stock of rental units by placing policies that require replacing the loss of six or more rental housing units, and by securing existing rental units within a new development. The rental housing market is considered to be healthy, as per council's opinion if the supply shows a positive continued net gain, and the overall vacancy rates for the City of Toronto is at or above 3.0 per cent for the preceding four consequent annual surveys as reported by $\mathrm{CMHC}$.

Although the above policies are a good start at incentivizing the increase in supply of a more diverse tenure for housing, it is important to understand that supply is typically inelastic in the short run and take a long time to respond and show change. A survey conducted by the Ontario Municipal Affairs and Housing towards developing a Housing Supply Action Plan identified barriers to new housing supply fell under main themes;

\subsubsection{RE-ASSESSING THE DEVELOPMENT APPROVAL PROCESS TO SPEED DEVELOPMENT PROCESS AND INCREASE SUPPLY}

To get a home from the drawing board to the market, a number of different planning policy and site specific approvals are required to be completed. Depending on the complexity of the application, many governmental bodies may need to be involved in the process, which results in duplication of work and delays of the development process. To give an example of that scenario, the City of Toronto's Official Plan Amendment (OPA) and Zoning By-law Amendment (ZBA) combined application guide, the proposed timeline for such a complex application from the submission of a complete application to council decision is 9 months (City of Toronto, 2019b). On average, such an application takes between 12 to 24 months at a minimum to achieve an OPA and ZBA in effect due to appeals. After which other planning process take place such as site planning which takes between 9 months and 12 months (Aird Berlis, 2017). 


\subsubsection{RE-ZONING SINGLE DETACHED ZONES USING GENTLE DENSITY TO PERMIT A MIX OF HOUSING TYPOLOGY}

According to the survey, the housing mix that is dictated by planning policy does not reflect the reality of market demand. For example there are not enough housing typologies built near transit, amenities, workplaces, schools for young families and seniors. The City of Toronto Official Plan states that over the next 30 years new growth will occur in only 25 per cent of the City's geographic land, while the remaining 75 per cent of the area are not expected to accommodate much growth. This calls for serious considerations and questioning of the policies in place. Of the 75 per cent of land area, 62 per cent are residential areas, of which 31 per cent are designated Neighbourhoods. Neighbourhoods are considered to be physically stable areas according to policies of the Official Plan. development within such areas "will help to protect and reinforce the existing physical character of these areas"(City of Toronto, 2006). Neighbourhoods contain a full range of typologies including, detached houses, semi-detached houses, duplexes, triplexes, townhouses as well as interspersed walkup apartments up to 4 storeys. Based on zoning analysis, in the City of Toronto there are more than 20,000 hectares of land zoned exclusively for single detached homes(Charlotte Balluch et al., 2018). Figure 43 demonstrates a city wide map of their geographical locations.

Figure 43: Map of Lands Designated Neighbourhood in the City of Toronto Sources: Diversifying Density: Re-Thinking Toronto's Yellowbelt

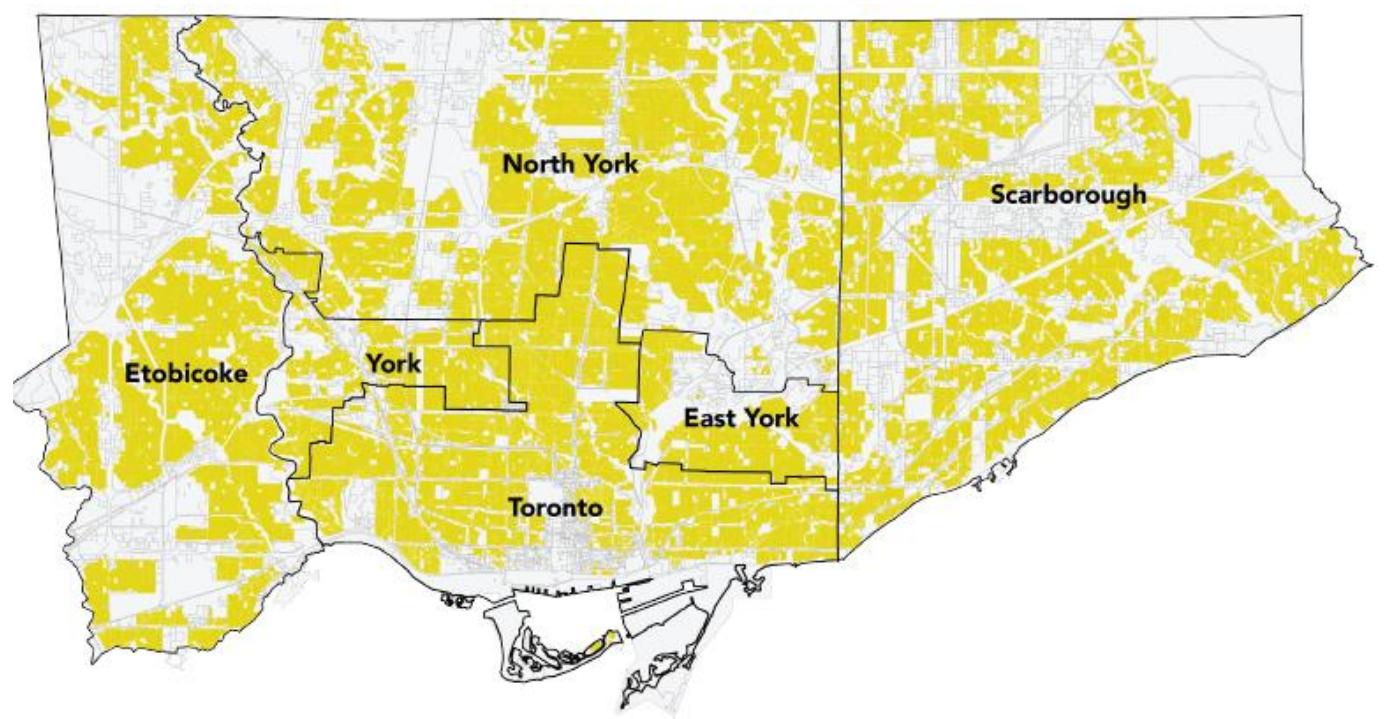


Hence promoting 'gentle density' is recommended as a solution to increasing the housing stock within the City and reduces the pressure on vacancy rates. Gentle density also referred to as missing middle housing is a term used to describe mid to low rise, as well as attached, low rise, ground oriented housing that can accommodate higher density than a detached house such as a duplex, triplex, townhouse, and stacked townhouse. As such if a duplex per hectare was added in areas that are zoned detached could accommodate an additional 45,000 people, while maintaining the low-rise character of neighbourhoods. Increasing housing stock may allow homeownership prices to decrease making it more affordable. Introducing gentle density in the appropriate areas is beneficial to the City because it utilizes existing services such as parks, libraries, transportation, etc. without having to raise new funding for capital expenditures. Another advantage of gentle density is that its helps boost the local economy by attracting new economic opportunities to the area and promote economic diversity to neighbourhoods. It also adds to creating healthy neighbourhoods, by decreasing auto dependency and increasing access to transit. Another major benefit for the city form integrating gentle density is an increase in municipal tax base. More housing developed within a neighbourhood may lead to an increase in property value, which would result in an increase in the property assessment value leading to higher municipal revenues in tax base. it is estimated that if 100,000 average sized households were added in the City of Toronto over a five year period, tax pressures would be alleviated by 10 per cent (Charlotte Balluch et al., 2018).

Figure 44: Examples of Different Types of Homes. 'Missing Middle' Housing Can Come In The Form of Midrise Buildings, Stacked Townhouses, Townhouses, and Semi-detached Houses, and Can be for Sale or for Rent.

Sources: Increasing Housing Supply In Ontario, Ministry of Municipal Affairs and Housing.
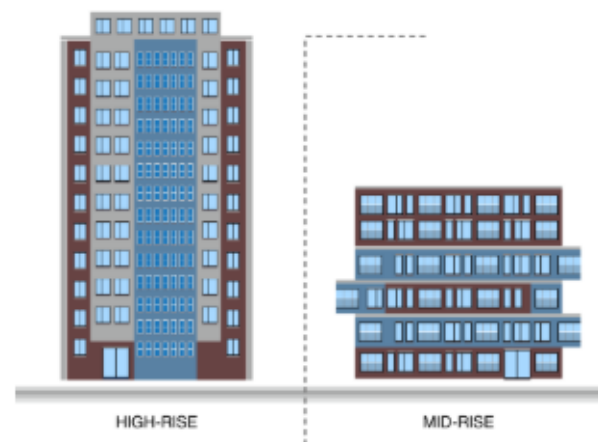

MISSING MIDDLE HOUSING

Another form of gently density but in an invisible form is permitting for the provision of second units. This is an option that has been suggested by the Ontario Long Term Affordable Housing Strategy Plan. Second units are self-contained residential units in which food preparation and 
sanitary facilities are provided. They are typically located with detached, semidetached or townhouse units. since November 2018, the City of Toronto has begun in the process of amending the Official Plan to allow for second units as the current policy does not reference or set out specific policies or provisions for second units (City of Toronto, 2006). Allowing second units will enable the general economic nature of neighborhoods across the city as homeowners will be able to earn extra income to help them afford the cost of the home. On the other hand, Renters will benefit from the increased supply and wider choice of location. This will also utilize the existing services and infrastructure so no funding for new services will be required. Secondary suits, a type of second units have been permitted since 2000; however under the City of Toronto Zoning By-law 569-2013, secondary units are only permitted after 5 years from the construction of the primary residence. The By-law does not permit secondary units in all townhouse tenure (City of Toronto, 2006). According to the survey, small landlords were finding it difficult to maintain their ability to remain within the housing market. Potential amendments to the Residential Tenancies Act 2006 (RTA) are also recommended to make it easier for landlords, while maintaining fairness to tenants against evictions poorly maintained rental housing and rent increase. The act sets rules to govern the amount of rents that landlord can charge for rental units. In the City of Toronto the landlord may only be permitted to increase rent if 12 months have elapsed. Rent increase is calculated based on the Ontario Consumer Price Index (CPI) as calculated on a monthly basis by Statistics Canada, but cannot exceed 2.5 per cent. In 2018 the recorded average increase was at 1.8 per cent (Social Justice Tribunals Ontario, 2019).

In general terms rent control aimed to help tenants by making housing affordable, it has made developers shy away from building new supply due to the economic feasibility of purpose built rentals. However the rule of rent control applying to all units including those privately owned was revoked by the Conservative Party in November 2018 to be limited only to existing supply but not to new development. This means that developers have incentives to build new supply as there is no cap on rent but it it also means that home rental pricing will still remain high until significant supply in the long run is achieved to offset the high price. As a long term strategy, holding of on rent control to increase supply is good, but it is recommended that the rate of supply is monitored and evaluated, as well as boosted using incentives streamlining the planning process to decrease the time frame. 


\subsubsection{RE-ASSESSING DEVELOPMENT COSTS INCREASES AFFECT DEVELOPMENT PACE AND WORKING THROUGH PUBLIC PRIVATE PARTNERSHIPS TO INCREASE SUPPLY}

Apart from increased construction cost and lack of housing supply, there is a lack of serviced land for development within the city, which has resulted in an increase in the price of land. This increase in price is reflected in the market price of units. Other costs associated with development imposed by governments such as municipal and educational development charges (DC), building and approval fees as well as Federal and provincial taxes make it difficult for developers to develop. By November of 2018, the City of Toronto had increased development charges by approximately 34 per cent, which is expected to result in approximately double the revenues by an increase of $\$ 240$ million in annual DC revenues by 2020 (City of Toronto, 2018b). Although many of the public services are funded by such charges and fees, however they often get passed on to the consumer rather than the developer. in addition to increased charges, the increased price of land has made the capital investment in certain typologies unattractive and sometimes financially unfeasible. Recommendations for this issue would be for City to work with private developers by utilizing Public Lands and entering into a public private partnership or by entering into a land lease, donating the land, or subsidizing the land by selling it at below market value. This would help alleviate some of the land cost pressures. Another way is to list all available developable vacant land within the City and to test their applicable planning policies to achieve the highest and best use of these sites. 
APPENDICIES

\section{APPENDIX A: WARD 9 OWNERSHIP ANALYSIS}

\begin{tabular}{|c|c|c|c|c|c|c|c|c|}
\hline & $\begin{array}{l}\text { Affordable } \\
\text { Purchase } \\
\text { Price }\end{array}$ & Detached & Semi detached & $\begin{array}{l}\text { Condominium } \\
\text { Townhouse }\end{array}$ & $\begin{array}{l}\text { Condominium } \\
\text { apartment }\end{array}$ & $\begin{array}{l}\text { Row/Town } \\
\text { house }\end{array}$ & Co-apartment & $\begin{array}{l}\text { Co-ownership } \\
\text { apartment }\end{array}$ \\
\hline TREB Total & & $\$ 945,580$ & $\$ 755,707$ & $\$ 567,290$ & $\$ 554,497$ & $\$ 679,164$ & $\$ 736,875$ & $\$ 471,667$ \\
\hline $\begin{array}{l}\text { City of } \\
\text { Toronto Total }\end{array}$ & 362,100 & $\$ 1,145,892$ & $\$ 939,859$ & $\$ 652,787$ & $\$ 594,381$ & $\$ 860,920$ & $\$ 889,167$ & $\$ 471,667$ \\
\hline Toronto West & 362,100 & $\$ 1,002,126$ & $\$ 831,798$ & $\$ 581,058$ & $\$ 485,890$ & $\$ 745,883$ & $\$ 270,000$ & - \\
\hline Toronto W01 & 362,100 & $\$ 1,429,250$ & $\$ 1,063,000$ & $\$ 672,000$ & $\$ 647,631$ & $\$ 1,050,000$ & - & - \\
\hline Toronto W02 & 362,100 & $\$ 1,139,167$ & $\$ 997,778$ & $\$ 681,250$ & $\$ 655,000$ & $\$ 866,500$ & - & - \\
\hline Toronto W03 & 362,100 & $\$ 727,308$ & $\$ 838,585$ & $\$ 614,667$ & $\$ 432,800$ & - & - & - \\
\hline Toronto W04 & 362,100 & $\$ 782,983$ & $\$ 808,000$ & $\$ 540,250$ & $\$ 401,919$ & $\$ 600,000$ & - & - \\
\hline Toronto W05 & 362,100 & $\$ 779,500$ & $\$ 680,375$ & $\$ 482,150$ & $\$ 306,798$ & $\$ 667,500$ & - & - \\
\hline Toronto W06 & 362,100 & $\$ 886,310$ & $\$ 1,259,350$ & $\$ 708,288$ & $\$ 566,972$ & $\$ 850,000$ & $\$ 270,000$ & - \\
\hline Toronto W07 & 362,100 & $\$ 1,180,100$ & - & - & $\$ 1,700,000$ & $\$ 955,000$ & - & - \\
\hline Toronto W08 & 362,100 & $\$ 1,361,787$ & $\$ 725,000$ & $\$ 484,267$ & $\$ 503,289$ & $\$ 917,000$ & - & - \\
\hline Toronto W09 & 362,100 & $\$ 1,261,250$ & $\$ 835,000$ & $\$ 627,780$ & $\$ 440,958$ & $\$ 665,633$ & - & - \\
\hline Toronto W10 & 362,100 & $\$ 686,291$ & $\$ 720,000$ & $\$ 454,000$ & $\$ 347,579$ & $\$ 719,000$ & - & - \\
\hline $\begin{array}{l}\text { Toronto } \\
\text { Central }\end{array}$ & 362,100 & $\$ 1,808,074$ & $\$ 1,189,483$ & $\$ 833,800$ & $\$ 695,790$ & $\$ 1,217,042$ & $\$ 1,198,750$ & $\$ 471,667$ \\
\hline Toronto C01 & 362,100 & $\$ 1,975,296$ & $\$ 1,340,600$ & $\$ 969,663$ & $\$ 730,564$ & $\$ 1,257,813$ & - & - \\
\hline Toronto C02 & 362,100 & $\$ 1,400,000$ & $\$ 1,145,000$ & $\$ 1,097,000$ & $\$ 1,318,999$ & - & - & - \\
\hline Toronto $\mathrm{C03}$ & 362,100 & $\$ 1,704,700$ & $\$ 1,104,333$ & - & $\$ 1,236,584$ & - & - & $\$ 390,000$ \\
\hline Toronto C04 & 362,100 & $\$ 1,835,333$ & - & $\$ 679,000$ & $\$ 665,482$ & - & - & - \\
\hline Toronto C06 & 362,100 & $\$ 1,179,500$ & - & - & $\$ 539,042$ & - & - & - \\
\hline Toronto C07 & 362,100 & $\$ 1,516,170$ & $\$ 751,000$ & $\$ 572,500$ & $\$ 609,597$ & - & - & - \\
\hline Toronto C08 & 362,100 & - & $\$ 1,559,333$ & $\$ 815,000$ & $\$ 606,765$ & $\$ 1,330,000$ & - & $\$ 320,000$ \\
\hline Toronto C09 & 362,100 & $\$ 2,550,375$ & $\$ 805,000$ & - & $\$ 1,033,750$ & - & $\$ 1,198,750$ & $\$ 705,000$ \\
\hline Toronto C10 & 362,100 & $\$ 1,561,800$ & $\$ 2,400,000$ & $\$ 662,500$ & $\$ 740,250$ & $\$ 1,225,000$ & - & - \\
\hline Toronto C11 & 362,100 & $\$ 1,912,348$ & - & $\$ 427,500$ & $\$ 458,200$ & - & - & - \\
\hline Toronto C12 & 362,100 & $\$ 3,619,800$ & - & $\$ 1,136,000$ & $\$ 730,000$ & - & - & - \\
\hline Toronto $\mathrm{C} 13$ & 362,100 & $\$ 2,157,667$ & $\$ 778,000$ & - & $\$ 566,500$ & $\$ 738,000$ & - & - \\
\hline Toronto C14 & 362,100 & $\$ 1,699,833$ & - & $\$ 811,000$ & $\$ 606,957$ & $\$ 1,249,000$ & - & - \\
\hline Toronto C15 & 362,100 & $\$ 1,155,472$ & $\$ 841,275$ & $\$ 623,578$ & $\$ 559,931$ & - & - & - \\
\hline Toronto East & 362,100 & $\$ 886,624$ & $\$ 914,754$ & $\$ 560,788$ & $\$ 428,075$ & $\$ 738,542$ & - & - \\
\hline Toronto E01 & 362,100 & $\$ 1,153,667$ & $\$ 1,064,160$ & $\$ 806,500$ & $\$ 647,175$ & $\$ 940,400$ & - & - \\
\hline Toronto E02 & 362,100 & $\$ 1,232,278$ & $\$ 1,158,486$ & $\$ 792,000$ & $\$ 950,000$ & - & - & - \\
\hline Toronto E03 & 362,100 & $\$ 1,017,386$ & $\$ 903,000$ & - & $\$ 480,708$ & - & - & - \\
\hline
\end{tabular}




\begin{tabular}{|c|c|c|c|c|c|c|c|c|}
\hline Toronto E04 & 362,100 & $\$ 755,472$ & $\$ 619,333$ & $\$ 603,917$ & $\$ 367,685$ & $\$ 681,000$ & - & - \\
\hline Toronto E05 & 362,100 & $\$ 873,831$ & $\$ 655,000$ & $\$ 560,000$ & $\$ 428,148$ & $\$ 805,000$ & - & - \\
\hline Toronto E06 & 362,100 & $\$ 826,765$ & - & - & $\$ 636,100$ & - & - & - \\
\hline Toronto E07 & 362,100 & $\$ 856,033$ & $\$ 723,500$ & $\$ 584,667$ & $\$ 376,876$ & - & - & - \\
\hline Toronto E08 & 362,100 & $\$ 891,091$ & - & $\$ 517,750$ & $\$ 398,437$ & $\$ 777,500$ & - & - \\
\hline Toronto E09 & 362,100 & $\$ 745,845$ & $\$ 657,333$ & $\$ 486,000$ & $\$ 421,281$ & - & - & - \\
\hline Toronto E10 & 362,100 & $\$ 800,989$ & $\$ 651,967$ & $\$ 446,600$ & $\$ 313,850$ & $\$ 652,833$ & - & - \\
\hline Toronto E11 & 362,100 & $\$ 792,375$ & $\$ 730,000$ & $\$ 483,583$ & $\$ 337,773$ & $\$ 582,250$ & - & - \\
\hline
\end{tabular}

\section{APPENDIX B: WARD 9 RENTAL ANALYSIS}

\begin{tabular}{|c|c|c|c|c|c|}
\hline & $\begin{array}{l}\text { Affordable Purchase } \\
\text { Price }\end{array}$ & Bachelor & One Bedroom & Two Bedroom & Three Bedroom \\
\hline TREB Total & & $\$ 1,821$ & $\$ 2,143$ & $\$ 2,774$ & $\$ 3,366$ \\
\hline City of Toronto Total & 2,020 & $\$ 1,838$ & $\$ 2,196$ & $\$ 2,944$ & $\$ 3,679$ \\
\hline Toronto West & 2,020 & $\$ 1,550$ & $\$ 2,023$ & $\$ 2,603$ & $\$ 2,981$ \\
\hline Toronto W01 & 2,020 & $\$ 1,450$ & $\$ 2,121$ & $\$ 2,780$ & $\$ 4,350$ \\
\hline Toronto W02 & 2,020 & - & $\$ 2,162$ & $\$ 2,887$ & - \\
\hline Toronto W03 & 2,020 & - & $\$ 1,900$ & - & $\$ 2,700$ \\
\hline Toronto W04 & 2,020 & $\$ 1,617$ & $\$ 1,882$ & $\$ 2,279$ & $\$ 3,350$ \\
\hline Toronto W05 & 2,020 & - & $\$ 1,957$ & $\$ 2,055$ & $\$ 2,000$ \\
\hline Toronto W06 & 2,020 & - & $\$ 2,093$ & $\$ 2,885$ & - \\
\hline Toronto W07 & 2,020 & - & $\$ 2,442$ & $\$ 3,050$ & - \\
\hline Toronto W08 & 2,020 & - & $\$ 1,957$ & $\$ 2,427$ & $\$ 2,625$ \\
\hline Toronto W09 & 2,020 & - & $\$ 1,750$ & $\$ 2,675$ & - \\
\hline Toronto W10 & 2,020 & - & $\$ 1,777$ & $\$ 2,131$ & $\$ 1,850$ \\
\hline Toronto Central & 2,020 & $\$ 1,857$ & $\$ 2,241$ & $\$ 3,080$ & $\$ 3,910$ \\
\hline Toronto C01 & 2,020 & $\$ 1,877$ & $\$ 2,319$ & $\$ 3,312$ & $\$ 4,330$ \\
\hline Toronto C02 & 2,020 & $\$ 1,913$ & $\$ 2,508$ & $\$ 4,063$ & $\$ 5,486$ \\
\hline Toronto $\mathrm{C03}$ & 2,020 & $\$ 1,650$ & $\$ 2,131$ & $\$ 2,848$ & $\$ 2,500$ \\
\hline Toronto C04 & 2,020 & - & $\$ 2,028$ & $\$ 2,600$ & $\$ 2,948$ \\
\hline Toronto C06 & 2,020 & - & $\$ 1,965$ & $\$ 2,369$ & $\$ 3,100$ \\
\hline Toronto C07 & 2,020 & - & $\$ 2,176$ & $\$ 2,812$ & $\$ 3,242$ \\
\hline Toronto C08 & 2,020 & $\$ 1,866$ & $\$ 2,238$ & $\$ 3,111$ & $\$ 4,669$ \\
\hline Toronto C09 & 2,020 & - & $\$ 2,302$ & $\$ 4,141$ & $\$ 4,600$ \\
\hline Toronto C10 & 2,020 & $\$ 1,700$ & $\$ 2,209$ & $\$ 2,989$ & - \\
\hline Toronto C11 & 2,020 & - & $\$ 1,833$ & $\$ 2,683$ & $\$ 2,325$ \\
\hline Toronto C12 & 2,020 & - & $\$ 2,350$ & $\$ 3,404$ & $\$ 3,150$ \\
\hline Toronto $\mathrm{C} 13$ & 2,020 & $\$ 1,690$ & $\$ 1,996$ & $\$ 2,404$ & - \\
\hline Toronto C14 & 2,020 & $\$ 1,800$ & $\$ 2,124$ & $\$ 2,717$ & $\$ 3,017$ \\
\hline Toronto C15 & 2,020 & $\$ 1,676$ & $\$ 2,031$ & $\$ 2,618$ & $\$ 3,113$ \\
\hline
\end{tabular}




\begin{tabular}{|c|c|c|c|c|c|}
\hline Toronto East & 2,020 & $\$ 1,536$ & $\$ 1,954$ & $\$ 2,203$ & $\$ 2,635$ \\
\hline Toronto E01 & 2,020 & - & $\$ 2,271$ & $\$ 2,835$ & $\$ 5,000$ \\
\hline Toronto E02 & 2,020 & $\$ 1,498$ & $\$ 2,266$ & $\$ 2,750$ & - \\
\hline Toronto E03 & 2,020 & - & $\$ 1,769$ & $\$ 2,125$ & - \\
\hline Toronto E04 & 2,020 & - & $\$ 1,874$ & $\$ 1,978$ & $\$ 2,200$ \\
\hline Toronto E05 & 2,020 & - & $\$ 1,803$ & $\$ 2,262$ & $\$ 2,395$ \\
\hline Toronto E06 & 2,020 & $\$ 1,400$ & $\$ 1,850$ & $\$ 2,017$ & $\$ 3,800$ \\
\hline Toronto E07 & 2,020 & - & $\$ 1,799$ & $\$ 2,089$ & $\$ 2,150$ \\
\hline Toronto E08 & 2,020 & - & $\$ 1,817$ & $\$ 2,088$ & $\$ 2,083$ \\
\hline Toronto E09 & 2,020 & $\$ 1,618$ & $\$ 1,923$ & $\$ 2,207$ & - \\
\hline Toronto E10 & 2,020 & - & - & - & - \\
\hline Toronto E11 & 2,020 & - & $\$ 1,675$ & $\$ 1,925$ & - \\
\hline
\end{tabular}

\section{APPENDIX C: WARD 10 OWNERSHIP ANALYSIS}

\begin{tabular}{|c|c|c|c|c|c|c|c|c|}
\hline & $\begin{array}{l}\text { Affordable Purchase } \\
\text { Price }\end{array}$ & Detached & $\begin{array}{l}\text { Semi } \\
\text { detached }\end{array}$ & $\begin{array}{l}\text { Condominium } \\
\text { Townhouse }\end{array}$ & $\begin{array}{l}\text { Condominium } \\
\text { apartment }\end{array}$ & $\begin{array}{l}\text { Row/Town } \\
\text { house }\end{array}$ & Co-apartment & $\begin{array}{l}\text { Co-ownership } \\
\text { apartment }\end{array}$ \\
\hline TREB Total & & $\$ 945,580$ & $\$ 755,707$ & $\$ 567,290$ & $\$ 554,497$ & $\$ 679,164$ & $\$ 736,875$ & $\$ 471,667$ \\
\hline City of Toronto Total & 461,800 & $\$ 1,145,892$ & $\$ 939,859$ & $\$ 652,787$ & $\$ 594,381$ & $\$ 860,920$ & $\$ 889,167$ & $\$ 471,667$ \\
\hline Toronto West & 461,800 & $\$ 1,002,126$ & $\$ 831,798$ & $\$ 581,058$ & $\$ 485,890$ & $\$ 745,883$ & $\$ 270,000$ & - \\
\hline Toronto W01 & 461,800 & $\$ 1,429,250$ & $\$ 1,063,000$ & $\$ 672,000$ & $\$ 647,631$ & $\$ 1,050,000$ & - & - \\
\hline Toronto W02 & 461,800 & $\$ 1,139,167$ & $\$ 997,778$ & $\$ 681,250$ & $\$ 655,000$ & $\$ 866,500$ & - & - \\
\hline Toronto W03 & 461,800 & $\$ 727,308$ & $\$ 838,585$ & $\$ 614,667$ & $\$ 432,800$ & - & - & - \\
\hline Toronto W04 & 461,800 & $\$ 782,983$ & $\$ 808,000$ & $\$ 540,250$ & $\$ 401,919$ & $\$ 600,000$ & - & - \\
\hline Toronto W05 & 461,800 & $\$ 779,500$ & $\$ 680,375$ & $\$ 482,150$ & $\$ 306,798$ & $\$ 667,500$ & - & - \\
\hline Toronto W06 & 461,800 & $\$ 886,310$ & $\$ 1,259,350$ & $\$ 708,288$ & $\$ 566,972$ & $\$ 850,000$ & $\$ 270,000$ & - \\
\hline Toronto W07 & 461,800 & $\$ 1,180,100$ & - & - & $\$ 1,700,000$ & $\$ 955,000$ & - & - \\
\hline Toronto W08 & 461,800 & $\$ 1,361,787$ & $\$ 725,000$ & $\$ 484,267$ & $\$ 503,289$ & $\$ 917,000$ & - & - \\
\hline Toronto W09 & 461,800 & $\$ 1,261,250$ & $\$ 835,000$ & $\$ 627,780$ & $\$ 440,958$ & $\$ 665,633$ & - & - \\
\hline Toronto W10 & 461,800 & $\$ 686,291$ & $\$ 720,000$ & $\$ 454,000$ & $\$ 347,579$ & $\$ 719,000$ & - & - \\
\hline Toronto Central & 461,800 & $\$ 1,808,074$ & $\$ 1,189,483$ & $\$ 833,800$ & $\$ 695,790$ & $\$ 1,217,042$ & $\$ 1,198,750$ & $\$ 471,667$ \\
\hline Toronto C01 & 461,800 & $\$ 1,975,296$ & $\$ 1,340,600$ & $\$ 969,663$ & $\$ 730,564$ & $\$ 1,257,813$ & - & - \\
\hline Toronto C02 & 461,800 & $\$ 1,400,000$ & $\$ 1,145,000$ & $\$ 1,097,000$ & $\$ 1,318,999$ & - & - & - \\
\hline Toronto C03 & 461,800 & $\$ 1,704,700$ & $\$ 1,104,333$ & - & $\$ 1,236,584$ & - & - & $\$ 390,000$ \\
\hline Toronto C04 & 461,800 & $\$ 1,835,333$ & - & $\$ 679,000$ & $\$ 665,482$ & - & - & - \\
\hline Toronto C06 & 461,800 & $\$ 1,179,500$ & - & - & $\$ 539,042$ & - & - & - \\
\hline Toronto C07 & 461,800 & $\$ 1,516,170$ & $\$ 751,000$ & $\$ 572,500$ & $\$ 609,597$ & - & - & - \\
\hline Toronto C08 & 461,800 & - & $\$ 1,559,333$ & $\$ 815,000$ & $\$ 606,765$ & $\$ 1,330,000$ & - & $\$ 320,000$ \\
\hline Toronto C09 & 461,800 & $\$ 2,550,375$ & $\$ 805,000$ & - & $\$ 1,033,750$ & - & $\$ 1,198,750$ & $\$ 705,000$ \\
\hline Toronto C10 & 461,800 & $\$ 1,561,800$ & $\$ 2,400,000$ & $\$ 662,500$ & $\$ 740,250$ & $\$ 1,225,000$ & - & - \\
\hline Toronto C11 & 461,800 & $\$ 1,912,348$ & - & $\$ 427,500$ & $\$ 458,200$ & - & - & - \\
\hline
\end{tabular}




\begin{tabular}{|c|c|c|c|c|c|c|c|c|}
\hline Toronto C12 & 461,800 & $\$ 3,619,800$ & - & $\$ 1,136,000$ & $\$ 730,000$ & - & - & - \\
\hline Toronto C13 & 461,800 & $\$ 2,157,667$ & $\$ 778,000$ & - & $\$ 566,500$ & $\$ 738,000$ & - & - \\
\hline Toronto C14 & 461,800 & $\$ 1,699,833$ & - & $\$ 811,000$ & $\$ 606,957$ & $\$ 1,249,000$ & - & - \\
\hline Toronto C15 & 461,800 & $\$ 1,155,472$ & $\$ 841,275$ & $\$ 623,578$ & $\$ 559,931$ & - & - & - \\
\hline Toronto East & 461,800 & $\$ 886,624$ & $\$ 914,754$ & $\$ 560,788$ & $\$ 428,075$ & $\$ 738,542$ & - & - \\
\hline Toronto E01 & 461,800 & $\$ 1,153,667$ & $\$ 1,064,160$ & $\$ 806,500$ & $\$ 647,175$ & $\$ 940,400$ & - & - \\
\hline Toronto E02 & 461,800 & $\$ 1,232,278$ & $\$ 1,158,486$ & $\$ 792,000$ & $\$ 950,000$ & - & - & - \\
\hline Toronto E03 & 461,800 & $\$ 1,017,386$ & $\$ 903,000$ & - & $\$ 480,708$ & - & - & - \\
\hline Toronto E04 & 461,800 & $\$ 755,472$ & $\$ 619,333$ & $\$ 603,917$ & $\$ 367,685$ & $\$ 681,000$ & - & - \\
\hline Toronto E05 & 461,800 & $\$ 873,831$ & $\$ 655,000$ & $\$ 560,000$ & $\$ 428,148$ & $\$ 805,000$ & - & - \\
\hline Toronto E06 & 461,800 & $\$ 826,765$ & - & - & $\$ 636,100$ & - & - & - \\
\hline Toronto E07 & 461,800 & $\$ 856,033$ & $\$ 723,500$ & $\$ 584,667$ & $\$ 376,876$ & - & - & - \\
\hline Toronto E08 & 461,800 & $\$ 891,091$ & - & $\$ 517,750$ & $\$ 398,437$ & $\$ 777,500$ & - & - \\
\hline Toronto E09 & 461,800 & $\$ 745,845$ & $\$ 657,333$ & $\$ 486,000$ & $\$ 421,281$ & - & - & - \\
\hline Toronto E10 & 461,800 & $\$ 800,989$ & $\$ 651,967$ & $\$ 446,600$ & $\$ 313,850$ & $\$ 652,833$ & - & - \\
\hline Toronto E11 & 461,800 & $\$ 792,375$ & $\$ 730,000$ & $\$ 483,583$ & $\$ 337,773$ & $\$ 582,250$ & - & - \\
\hline
\end{tabular}

\section{APPENDIX D: WARD 10 RENTAL ANALYSIS}

\begin{tabular}{|c|c|c|c|c|c|}
\hline & $\begin{array}{l}\text { Affordable Purchase } \\
\text { Price }\end{array}$ & Bachelor & One Bedroom & Two Bedroom & Three Bedroom \\
\hline TREB Total & & $\$ 1,821$ & $\$ 2,143$ & $\$ 2,774$ & $\$ 3,366$ \\
\hline City of Toronto Total & 2,576 & $\$ 1,838$ & $\$ 2,196$ & $\$ 2,944$ & $\$ 3,679$ \\
\hline Toronto West & 2,576 & $\$ 1,550$ & $\$ 2,023$ & $\$ 2,603$ & $\$ 2,981$ \\
\hline Toronto W01 & 2,576 & $\$ 1,450$ & $\$ 2,121$ & $\$ 2,780$ & $\$ 4,350$ \\
\hline Toronto W02 & 2,576 & - & $\$ 2,162$ & $\$ 2,887$ & - \\
\hline Toronto W03 & 2,576 & - & $\$ 1,900$ & - & $\$ 2,700$ \\
\hline Toronto W04 & 2,576 & $\$ 1,617$ & $\$ 1,882$ & $\$ 2,279$ & $\$ 3,350$ \\
\hline Toronto W05 & 2,576 & - & $\$ 1,957$ & $\$ 2,055$ & $\$ 2,000$ \\
\hline Toronto W06 & 2,576 & - & $\$ 2,093$ & $\$ 2,885$ & - \\
\hline Toronto W07 & 2,576 & - & $\$ 2,442$ & $\$ 3,050$ & - \\
\hline Toronto W08 & 2,576 & - & $\$ 1,957$ & $\$ 2,427$ & $\$ 2,625$ \\
\hline Toronto W09 & 2,576 & - & $\$ 1,750$ & $\$ 2,675$ & - \\
\hline Toronto W10 & 2,576 & - & $\$ 1,777$ & $\$ 2,131$ & $\$ 1,850$ \\
\hline Toronto Central & 2,576 & $\$ 1,857$ & $\$ 2,241$ & $\$ 3,080$ & $\$ 3,910$ \\
\hline Toronto C01 & 2,576 & $\$ 1,877$ & $\$ 2,319$ & $\$ 3,312$ & $\$ 4,330$ \\
\hline Toronto C02 & 2,576 & $\$ 1,913$ & $\$ 2,508$ & $\$ 4,063$ & $\$ 5,486$ \\
\hline Toronto C03 & 2,576 & $\$ 1,650$ & $\$ 2,131$ & $\$ 2,848$ & $\$ 2,500$ \\
\hline Toronto C04 & 2,576 & - & $\$ 2,028$ & $\$ 2,600$ & $\$ 2,948$ \\
\hline Toronto C06 & 2,576 & - & $\$ 1,965$ & $\$ 2,369$ & $\$ 3,100$ \\
\hline Toronto C07 & 2,576 & - & $\$ 2,176$ & $\$ 2,812$ & $\$ 3,242$ \\
\hline
\end{tabular}




\begin{tabular}{|c|c|c|c|c|c|}
\hline Toronto C08 & 2,576 & $\$ 1,866$ & $\$ 2,238$ & $\$ 3,111$ & $\$ 4,669$ \\
\hline Toronto C09 & 2,576 & - & $\$ 2,302$ & $\$ 4,141$ & $\$ 4,600$ \\
\hline Toronto C10 & 2,576 & $\$ 1,700$ & $\$ 2,209$ & $\$ 2,989$ & - \\
\hline Toronto C11 & 2,576 & - & $\$ 1,833$ & $\$ 2,683$ & $\$ 2,325$ \\
\hline Toronto $\mathrm{C} 12$ & 2,576 & - & $\$ 2,350$ & $\$ 3,404$ & $\$ 3,150$ \\
\hline Toronto $\mathrm{C} 13$ & 2,576 & $\$ 1,690$ & $\$ 1,996$ & $\$ 2,404$ & - \\
\hline Toronto C14 & 2,576 & $\$ 1,800$ & $\$ 2,124$ & $\$ 2,717$ & $\$ 3,017$ \\
\hline Toronto C15 & 2,576 & $\$ 1,676$ & $\$ 2,031$ & $\$ 2,618$ & $\$ 3,113$ \\
\hline Toronto East & 2,576 & $\$ 1,536$ & $\$ 1,954$ & $\$ 2,203$ & $\$ 2,635$ \\
\hline Toronto E01 & 2,576 & - & $\$ 2,271$ & $\$ 2,835$ & $\$ 5,000$ \\
\hline Toronto E02 & 2,576 & $\$ 1,498$ & $\$ 2,266$ & $\$ 2,750$ & - \\
\hline Toronto E03 & 2,576 & - & $\$ 1,769$ & $\$ 2,125$ & - \\
\hline Toronto E04 & 2,576 & - & $\$ 1,874$ & $\$ 1,978$ & $\$ 2,200$ \\
\hline Toronto E05 & 2,576 & - & $\$ 1,803$ & $\$ 2,262$ & $\$ 2,395$ \\
\hline Toronto E06 & 2,576 & $\$ 1,400$ & $\$ 1,850$ & $\$ 2,017$ & $\$ 3,800$ \\
\hline Toronto E07 & 2,576 & - & $\$ 1,799$ & $\$ 2,089$ & $\$ 2,150$ \\
\hline Toronto E08 & 2,576 & - & $\$ 1,817$ & $\$ 2,088$ & $\$ 2,083$ \\
\hline Toronto E09 & 2,576 & $\$ 1,618$ & $\$ 1,923$ & $\$ 2,207$ & - \\
\hline Toronto E10 & 2,576 & - & - & - & - \\
\hline Toronto E11 & 2,576 & - & $\$ 1,675$ & $\$ 1,925$ & - \\
\hline
\end{tabular}

\section{APPENDIX E: WARD 11 OWNERSHIP ANALYSIS}

\begin{tabular}{|c|c|c|c|c|c|c|c|c|}
\hline & $\begin{array}{l}\text { Affordable } \\
\text { Purchase } \\
\text { Price }\end{array}$ & Detached & $\begin{array}{l}\text { Semi } \\
\text { detached }\end{array}$ & $\begin{array}{l}\text { Condominium } \\
\text { Townhouse }\end{array}$ & $\begin{array}{l}\text { Condominium } \\
\text { apartment }\end{array}$ & $\begin{array}{l}\text { Row/Town } \\
\text { house }\end{array}$ & $\begin{array}{l}\text { Co- } \\
\text { apartment }\end{array}$ & $\begin{array}{l}\text { Co- } \\
\text { ownership } \\
\text { apartment }\end{array}$ \\
\hline TREB Total & & $\$ 945,580$ & $\$ 755,707$ & $\$ 567,290$ & $\$ 554,497$ & $\$ 679,164$ & $\$ 736,875$ & $\$ 471,667$ \\
\hline City of Toronto Total & 765,800 & $\$ 1,145,892$ & $\$ 939,859$ & $\$ 652,787$ & $\$ 594,381$ & $\$ 860,920$ & $\$ 889,167$ & $\$ 471,667$ \\
\hline Toronto West & 765,800 & $\$ 1,002,126$ & $\$ 831,798$ & $\$ 581,058$ & $\$ 485,890$ & $\$ 745,883$ & $\$ 270,000$ & - \\
\hline Toronto W01 & 765,800 & $\$ 1,429,250$ & $\$ 1,063,000$ & $\$ 672,000$ & $\$ 647,631$ & $\$ 1,050,000$ & - & - \\
\hline Toronto W02 & 765,800 & $\$ 1,139,167$ & $\$ 997,778$ & $\$ 681,250$ & $\$ 655,000$ & $\$ 866,500$ & F- & - \\
\hline Toronto W03 & 765,800 & $\$ 727,308$ & $\$ 838,585$ & $\$ 614,667$ & $\$ 432,800$ & & - & - \\
\hline Toronto W04 & 765,800 & $\$ 782,983$ & $\$ 808,000$ & $\$ 540,250$ & $\$ 401,919$ & $\$ 600,000$ & - & - \\
\hline Toronto W05 & 765,800 & $\$ 779,500$ & $\$ 680,375$ & $\$ 482,150$ & $\$ 306,798$ & $\$ 667,500$ & - & - \\
\hline Toronto W06 & 765,800 & $\$ 886,310$ & $\$ 1,259,350$ & $\$ 708,288$ & $\$ 566,972$ & $\$ 850,000$ & $\$ 270,000$ & - \\
\hline Toronto W07 & 765,800 & $\$ 1,180,100$ & & - & $\$ 1,700,000$ & $\$ 955,000$ & - & - \\
\hline Toronto W08 & 765,800 & $\$ 1,361,787$ & $\$ 725,000$ & $\$ 484,267$ & $\$ 503,289$ & $\$ 917,000$ & - & - \\
\hline Toronto W09 & 765,800 & $\$ 1,261,250$ & $\$ 835,000$ & $\$ 627,780$ & $\$ 440,958$ & $\$ 665,633$ & - & - \\
\hline Toronto W10 & 765,800 & $\$ 686,291$ & $\$ 720,000$ & $\$ 454,000$ & $\$ 347,579$ & $\$ 719,000$ & - & - \\
\hline Toronto Central & 765,800 & $\$ 1,808,074$ & $\$ 1,189,483$ & $\$ 833,800$ & $\$ 695,790$ & $\$ 1,217,042$ & $\$ 1,198,750$ & $\$ 471,667$ \\
\hline Toronto C01 & 765,800 & $\$ 1,975,296$ & $\$ 1,340,600$ & $\$ 969,663$ & $\$ 730,564$ & $\$ 1,257,813$ & F & \\
\hline
\end{tabular}




\begin{tabular}{|c|c|c|c|c|c|c|c|c|}
\hline Toronto C02 & 765,800 & $\$ 1,400,000$ & $\$ 1,145,000$ & $\$ 1,097,000$ & $\$ 1,318,999$ & - & - & - \\
\hline Toronto C03 & 765,800 & $\$ 1,704,700$ & $\$ 1,104,333$ & - & $\$ 1,236,584$ & - & - & $\$ 390,000$ \\
\hline Toronto C04 & 765,800 & $\$ 1,835,333$ & - & $\$ 679,000$ & $\$ 665,482$ & - & - & - \\
\hline Toronto C06 & 765,800 & $\$ 1,179,500$ & - & - & $\$ 539,042$ & - & - & - \\
\hline Toronto C07 & 765,800 & $\$ 1,516,170$ & $\$ 751,000$ & $\$ 572,500$ & $\$ 609,597$ & - & - & - \\
\hline Toronto C08 & 765,800 & - & $\$ 1,559,333$ & $\$ 815,000$ & $\$ 606,765$ & $\$ 1,330,000$ & - & $\$ 320,000$ \\
\hline Toronto C09 & 765,800 & $\$ 2,550,375$ & $\$ 805,000$ & - & $\$ 1,033,750$ & - & $\$ 1,198,750$ & $\$ 705,000$ \\
\hline Toronto C10 & 765,800 & $\$ 1,561,800$ & $\$ 2,400,000$ & $\$ 662,500$ & $\$ 740,250$ & $\$ 1,225,000$ & - & - \\
\hline Toronto C11 & 765,800 & $\$ 1,912,348$ & - & $\$ 427,500$ & $\$ 458,200$ & - & - & - \\
\hline Toronto C12 & 765,800 & $\$ 3,619,800$ & - & $\$ 1,136,000$ & $\$ 730,000$ & - & - & - \\
\hline Toronto C13 & 765,800 & $\$ 2,157,667$ & $\$ 778,000$ & - & $\$ 566,500$ & $\$ 738,000$ & - & - \\
\hline Toronto C14 & 765,800 & $\$ 1,699,833$ & - & $\$ 811,000$ & $\$ 606,957$ & $\$ 1,249,000$ & - & - \\
\hline Toronto C15 & 765,800 & $\$ 1,155,472$ & $\$ 841,275$ & $\$ 623,578$ & $\$ 559,931$ & - & - & - \\
\hline Toronto East & 765,800 & $\$ 886,624$ & $\$ 914,754$ & $\$ 560,788$ & $\$ 428,075$ & $\$ 738,542$ & - & - \\
\hline Toronto E01 & 765,800 & $\$ 1,153,667$ & $\$ 1,064,160$ & $\$ 806,500$ & $\$ 647,175$ & $\$ 940,400$ & - & - \\
\hline Toronto E02 & 765,800 & $\$ 1,232,278$ & $\$ 1,158,486$ & $\$ 792,000$ & $\$ 950,000$ & - & - & - \\
\hline Toronto E03 & 765,800 & $\$ 1,017,386$ & $\$ 903,000$ & - & $\$ 480,708$ & - & - & - \\
\hline Toronto E04 & 765,800 & $\$ 755,472$ & $\$ 619,333$ & $\$ 603,917$ & $\$ 367,685$ & $\$ 681,000$ & - & - \\
\hline Toronto E05 & 765,800 & $\$ 873,831$ & $\$ 655,000$ & $\$ 560,000$ & $\$ 428,148$ & $\$ 805,000$ & - & - \\
\hline Toronto E06 & 765,800 & $\$ 826,765$ & - & - & $\$ 636,100$ & - & - & - \\
\hline Toronto E07 & 765,800 & $\$ 856,033$ & $\$ 723,500$ & $\$ 584,667$ & $\$ 376,876$ & - & - & - \\
\hline Toronto E08 & 765,800 & $\$ 891,091$ & - & $\$ 517,750$ & $\$ 398,437$ & $\$ 777,500$ & - & - \\
\hline Toronto E09 & 765,800 & $\$ 745,845$ & $\$ 657,333$ & $\$ 486,000$ & $\$ 421,281$ & - & - & - \\
\hline Toronto E10 & 765,800 & $\$ 800,989$ & $\$ 651,967$ & $\$ 446,600$ & $\$ 313,850$ & $\$ 652,833$ & - & - \\
\hline Toronto E11 & 765,800 & $\$ 792,375$ & $\$ 730,000$ & $\$ 483,583$ & $\$ 337,773$ & $\$ 582,250$ & - & - \\
\hline
\end{tabular}

\section{APPENDIX F: WARD 11 RENTAL ANALYSIS}

\begin{tabular}{|c|c|c|c|c|c|}
\hline & $\begin{array}{l}\text { Affordable Purchase } \\
\text { Price }\end{array}$ & Bachelor & One Bedroom & Two Bedroom & Three Bedroom \\
\hline TREB Total & & $\$ 1,821$ & $\$ 2,143$ & $\$ 2,774$ & $\$ 3,366$ \\
\hline City of Toronto Total & 4,271 & $\$ 1,838$ & $\$ 2,196$ & $\$ 2,944$ & $\$ 3,679$ \\
\hline Toronto West & 4,271 & $\$ 1,550$ & $\$ 2,023$ & $\$ 2,603$ & $\$ 2,981$ \\
\hline Toronto W01 & 4,271 & $\$ 1,450$ & $\$ 2,121$ & $\$ 2,780$ & $\$ 4,350$ \\
\hline Toronto W02 & 4,271 & - & $\$ 2,162$ & $\$ 2,887$ & - \\
\hline Toronto W03 & 4,271 & - & $\$ 1,900$ & - & $\$ 2,700$ \\
\hline Toronto W04 & 4,271 & $\$ 1,617$ & $\$ 1,882$ & $\$ 2,279$ & $\$ 3,350$ \\
\hline Toronto W05 & 4,271 & - & $\$ 1,957$ & $\$ 2,055$ & $\$ 2,000$ \\
\hline Toronto W06 & 4,271 & - & $\$ 2,093$ & $\$ 2,885$ & - \\
\hline Toronto W07 & 4,271 & - & $\$ 2,442$ & $\$ 3,050$ & - \\
\hline Toronto W08 & 4,271 & - & $\$ 1,957$ & $\$ 2,427$ & $\$ 2,625$ \\
\hline
\end{tabular}




\begin{tabular}{|c|c|c|c|c|c|}
\hline Toronto W09 & 4,271 & - & $\$ 1,750$ & $\$ 2,675$ & - \\
\hline Toronto W10 & 4,271 & - & $\$ 1,777$ & $\$ 2,131$ & $\$ 1,850$ \\
\hline Toronto Central & 4,271 & $\$ 1,857$ & $\$ 2,241$ & $\$ 3,080$ & $\$ 3,910$ \\
\hline Toronto C01 & 4,271 & $\$ 1,877$ & $\$ 2,319$ & $\$ 3,312$ & $\$ 4,330$ \\
\hline Toronto C02 & 4,271 & $\$ 1,913$ & $\$ 2,508$ & $\$ 4,063$ & $\$ 5,486$ \\
\hline Toronto C03 & 4,271 & $\$ 1,650$ & $\$ 2,131$ & $\$ 2,848$ & $\$ 2,500$ \\
\hline Toronto C04 & 4,271 & - & $\$ 2,028$ & $\$ 2,600$ & $\$ 2,948$ \\
\hline Toronto C06 & 4,271 & - & $\$ 1,965$ & $\$ 2,369$ & $\$ 3,100$ \\
\hline Toronto C07 & 4,271 & - & $\$ 2,176$ & $\$ 2,812$ & $\$ 3,242$ \\
\hline Toronto C08 & 4,271 & $\$ 1,866$ & $\$ 2,238$ & $\$ 3,111$ & $\$ 4,669$ \\
\hline Toronto C09 & 4,271 & - & $\$ 2,302$ & $\$ 4,141$ & $\$ 4,600$ \\
\hline Toronto C10 & 4,271 & $\$ 1,700$ & $\$ 2,209$ & $\$ 2,989$ & - \\
\hline Toronto C11 & 4,271 & - & $\$ 1,833$ & $\$ 2,683$ & $\$ 2,325$ \\
\hline Toronto C12 & 4,271 & - & $\$ 2,350$ & $\$ 3,404$ & $\$ 3,150$ \\
\hline Toronto C13 & 4,271 & $\$ 1,690$ & $\$ 1,996$ & $\$ 2,404$ & - \\
\hline Toronto C14 & 4,271 & $\$ 1,800$ & $\$ 2,124$ & $\$ 2,717$ & $\$ 3,017$ \\
\hline Toronto C15 & 4,271 & $\$ 1,676$ & $\$ 2,031$ & $\$ 2,618$ & $\$ 3,113$ \\
\hline Toronto East & 4,271 & $\$ 1,536$ & $\$ 1,954$ & $\$ 2,203$ & $\$ 2,635$ \\
\hline Toronto E01 & 4,271 & - & $\$ 2,271$ & $\$ 2,835$ & $\$ 5,000$ \\
\hline Toronto E02 & 4,271 & $\$ 1,498$ & $\$ 2,266$ & $\$ 2,750$ & - \\
\hline Toronto E03 & 4,271 & - & $\$ 1,769$ & $\$ 2,125$ & - \\
\hline Toronto E04 & 4,271 & - & $\$ 1,874$ & $\$ 1,978$ & $\$ 2,200$ \\
\hline Toronto E05 & 4,271 & - & $\$ 1,803$ & $\$ 2,262$ & $\$ 2,395$ \\
\hline Toronto E06 & 4,271 & $\$ 1,400$ & $\$ 1,850$ & $\$ 2,017$ & $\$ 3,800$ \\
\hline Toronto E07 & 4,271 & - & $\$ 1,799$ & $\$ 2,089$ & $\$ 2,150$ \\
\hline Toronto E08 & 4,271 & - & $\$ 1,817$ & $\$ 2,088$ & $\$ 2,083$ \\
\hline Toronto E09 & 4,271 & $\$ 1,618$ & $\$ 1,923$ & $\$ 2,207$ & - \\
\hline Toronto E10 & 4,271 & - & - & - & - \\
\hline Toronto E11 & 4,271 & - & $\$ 1,675$ & $\$ 1,925$ & - \\
\hline
\end{tabular}

\section{APPENDIX G: WARD 13 OWNERSHIP ANALYSIS}

\begin{tabular}{|c|c|c|c|c|c|c|c|c|}
\hline & $\begin{array}{l}\text { Affordable Purchase } \\
\text { Price }\end{array}$ & Detached & $\begin{array}{l}\text { Semi } \\
\text { detached }\end{array}$ & $\begin{array}{l}\text { Condominium } \\
\text { Townhouse }\end{array}$ & $\begin{array}{l}\text { Condominium } \\
\text { apartment }\end{array}$ & $\begin{array}{l}\text { Row/Town } \\
\text { house }\end{array}$ & Co-apartment & $\begin{array}{l}\text { Co-ownership } \\
\text { apartment }\end{array}$ \\
\hline TREB Total & & $\$ 945,580$ & $\$ 755,707$ & $\$ 567,290$ & $\$ 554,497$ & $\$ 679,164$ & $\$ 736,875$ & $\$ 471,667$ \\
\hline City of Toronto Total & 337,900 & $\$ 1,145,892$ & $\$ 939,859$ & $\$ 652,787$ & $\$ 594,381$ & $\$ 860,920$ & $\$ 889,167$ & $\$ 471,667$ \\
\hline Toronto West & 337,900 & $\$ 1,002,126$ & $\$ 831,798$ & $\$ 581,058$ & $\$ 485,890$ & $\$ 745,883$ & $\$ 270,000$ & - \\
\hline Toronto W01 & 337,900 & $\$ 1,429,250$ & $\$ 1,063,000$ & $\$ 672,000$ & $\$ 647,631$ & $\$ 1,050,000$ & - & - \\
\hline Toronto W02 & 337,900 & $\$ 1,139,167$ & $\$ 997,778$ & $\$ 681,250$ & $\$ 655,000$ & $\$ 866,500$ & - & - \\
\hline Toronto W03 & 337,900 & $\$ 727,308$ & $\$ 838,585$ & $\$ 614,667$ & $\$ 432,800$ & - & - & - \\
\hline
\end{tabular}




\begin{tabular}{|c|c|c|c|c|c|c|c|c|}
\hline Toronto W04 & 337,900 & $\$ 782,983$ & $\$ 808,000$ & $\$ 540,250$ & $\$ 401,919$ & $\$ 600,000$ & - & - \\
\hline Toronto W05 & 337,900 & $\$ 779,500$ & $\$ 680,375$ & $\$ 482,150$ & $\$ 306,798$ & $\$ 667,500$ & - & - \\
\hline Toronto W06 & 337,900 & $\$ 886,310$ & $\$ 1,259,350$ & $\$ 708,288$ & $\$ 566,972$ & $\$ 850,000$ & $\$ 270,000$ & - \\
\hline Toronto W07 & 337,900 & $\$ 1,180,100$ & - & - & $\$ 1,700,000$ & $\$ 955,000$ & - & - \\
\hline Toronto W08 & 337,900 & $\$ 1,361,787$ & $\$ 725,000$ & $\$ 484,267$ & $\$ 503,289$ & $\$ 917,000$ & - & - \\
\hline Toronto W09 & 337,900 & $\$ 1,261,250$ & $\$ 835,000$ & $\$ 627,780$ & $\$ 440,958$ & $\$ 665,633$ & - & - \\
\hline Toronto W10 & 337,900 & $\$ 686,291$ & $\$ 720,000$ & $\$ 454,000$ & $\$ 347,579$ & $\$ 719,000$ & - & - \\
\hline Toronto Central & 337,900 & $\$ 1,808,074$ & $\$ 1,189,483$ & $\$ 833,800$ & $\$ 695,790$ & $\$ 1,217,042$ & $\$ 1,198,750$ & $\$ 471,667$ \\
\hline Toronto C01 & 337,900 & $\$ 1,975,296$ & $\$ 1,340,600$ & $\$ 969,663$ & $\$ 730,564$ & $\$ 1,257,813$ & - & - \\
\hline Toronto C02 & 337,900 & $\$ 1,400,000$ & $\$ 1,145,000$ & $\$ 1,097,000$ & $\$ 1,318,999$ & - & - & - \\
\hline Toronto C03 & 337,900 & $\$ 1,704,700$ & $\$ 1,104,333$ & - & $\$ 1,236,584$ & - & - & $\$ 390,000$ \\
\hline Toronto C04 & 337,900 & $\$ 1,835,333$ & - & $\$ 679,000$ & $\$ 665,482$ & - & - & - \\
\hline Toronto C06 & 337,900 & $\$ 1,179,500$ & - & - & $\$ 539,042$ & - & - & - \\
\hline Toronto C07 & 337,900 & $\$ 1,516,170$ & $\$ 751,000$ & $\$ 572,500$ & $\$ 609,597$ & - & - & - \\
\hline Toronto C08 & 337,900 & - & $\$ 1,559,333$ & $\$ 815,000$ & $\$ 606,765$ & $\$ 1,330,000$ & - & $\$ 320,000$ \\
\hline Toronto C09 & 337,900 & $\$ 2,550,375$ & $\$ 805,000$ & - & $\$ 1,033,750$ & - & $\$ 1,198,750$ & $\$ 705,000$ \\
\hline Toronto C10 & 337,900 & $\$ 1,561,800$ & $\$ 2,400,000$ & $\$ 662,500$ & $\$ 740,250$ & $\$ 1,225,000$ & - & - \\
\hline Toronto C11 & 337,900 & $\$ 1,912,348$ & - & $\$ 427,500$ & $\$ 458,200$ & - & - & - \\
\hline Toronto C12 & 337,900 & $\$ 3,619,800$ & - & $\$ 1,136,000$ & $\$ 730,000$ & - & - & - \\
\hline Toronto C13 & 337,900 & $\$ 2,157,667$ & $\$ 778,000$ & - & $\$ 566,500$ & $\$ 738,000$ & - & - \\
\hline Toronto C14 & 337,900 & $\$ 1,699,833$ & - & $\$ 811,000$ & $\$ 606,957$ & $\$ 1,249,000$ & - & - \\
\hline Toronto C15 & 337,900 & $\$ 1,155,472$ & $\$ 841,275$ & $\$ 623,578$ & $\$ 559,931$ & - & - & - \\
\hline Toronto East & 337,900 & $\$ 886,624$ & $\$ 914,754$ & $\$ 560,788$ & $\$ 428,075$ & $\$ 738,542$ & - & - \\
\hline Toronto E01 & 337,900 & $\$ 1,153,667$ & $\$ 1,064,160$ & $\$ 806,500$ & $\$ 647,175$ & $\$ 940,400$ & - & - \\
\hline Toronto E02 & 337,900 & $\$ 1,232,278$ & $\$ 1,158,486$ & $\$ 792,000$ & $\$ 950,000$ & - & - & - \\
\hline Toronto E03 & 337,900 & $\$ 1,017,386$ & $\$ 903,000$ & - & $\$ 480,708$ & - & - & - \\
\hline Toronto E04 & 337,900 & $\$ 755,472$ & $\$ 619,333$ & $\$ 603,917$ & $\$ 367,685$ & $\$ 681,000$ & - & - \\
\hline Toronto E05 & 337,900 & $\$ 873,831$ & $\$ 655,000$ & $\$ 560,000$ & $\$ 428,148$ & $\$ 805,000$ & - & - \\
\hline Toronto E06 & 337,900 & $\$ 826,765$ & - & - & $\$ 636,100$ & - & - & - \\
\hline Toronto E07 & 337,900 & $\$ 856,033$ & $\$ 723,500$ & $\$ 584,667$ & $\$ 376,876$ & - & - & - \\
\hline Toronto E08 & 337,900 & $\$ 891,091$ & - & $\$ 517,750$ & $\$ 398,437$ & $\$ 777,500$ & - & - \\
\hline Toronto E09 & 337,900 & $\$ 745,845$ & $\$ 657,333$ & $\$ 486,000$ & $\$ 421,281$ & - & - & - \\
\hline Toronto E10 & 337,900 & $\$ 800,989$ & $\$ 651,967$ & $\$ 446,600$ & $\$ 313,850$ & $\$ 652,833$ & - & - \\
\hline Toronto E11 & 337,900 & $\$ 792,375$ & $\$ 730,000$ & $\$ 483,583$ & $\$ 337,773$ & $\$ 582,250$ & - & - \\
\hline
\end{tabular}

\section{APPENDIX H: WARD 13 RENTAL ANALYSIS}

\begin{tabular}{|c|c|c|c|c|c|}
\hline & $\begin{array}{l}\text { Affordable Purchase } \\
\text { Price }\end{array}$ & Bachelor & One Bedroom & Two Bedroom & Three Bedroom \\
\hline TREB Total & & $\$ 1,821$ & $\$ 2,143$ & $\$ 2,774$ & $\$ 3,366$ \\
\hline City of Toronto Total & 1,885 & $\$ 1,838$ & $\$ 2,196$ & $\$ 2,944$ & $\$ 3,679$ \\
\hline Toronto West & 1,885 & $\$ 1,550$ & $\$ 2,023$ & $\$ 2,603$ & $\$ 2,981$ \\
\hline
\end{tabular}




\begin{tabular}{|c|c|c|c|c|c|}
\hline Toronto W01 & 1,885 & $\$ 1,450$ & $\$ 2,121$ & $\$ 2,780$ & $\$ 4,350$ \\
\hline Toronto W02 & 1,885 & - & $\$ 2,162$ & $\$ 2,887$ & - \\
\hline Toronto W03 & 1,885 & - & $\$ 1,900$ & - & $\$ 2,700$ \\
\hline Toronto W04 & 1,885 & $\$ 1,617$ & $\$ 1,882$ & $\$ 2,279$ & $\$ 3,350$ \\
\hline Toronto W05 & 1,885 & - & $\$ 1,957$ & $\$ 2,055$ & $\$ 2,000$ \\
\hline Toronto W06 & 1,885 & - & $\$ 2,093$ & $\$ 2,885$ & - \\
\hline Toronto W07 & 1,885 & - & $\$ 2,442$ & $\$ 3,050$ & - \\
\hline Toronto W08 & 1,885 & - & $\$ 1,957$ & $\$ 2,427$ & $\$ 2,625$ \\
\hline Toronto W09 & 1,885 & - & $\$ 1,750$ & $\$ 2,675$ & - \\
\hline Toronto W10 & 1,885 & - & $\$ 1,777$ & $\$ 2,131$ & $\$ 1,850$ \\
\hline Toronto Central & 1,885 & $\$ 1,857$ & $\$ 2,241$ & $\$ 3,080$ & $\$ 3,910$ \\
\hline Toronto C01 & 1,885 & $\$ 1,877$ & $\$ 2,319$ & $\$ 3,312$ & $\$ 4,330$ \\
\hline Toronto C02 & 1,885 & $\$ 1,913$ & $\$ 2,508$ & $\$ 4,063$ & $\$ 5,486$ \\
\hline Toronto C03 & 1,885 & $\$ 1,650$ & $\$ 2,131$ & $\$ 2,848$ & $\$ 2,500$ \\
\hline Toronto C04 & 1,885 & - & $\$ 2,028$ & $\$ 2,600$ & $\$ 2,948$ \\
\hline Toronto C06 & 1,885 & - & $\$ 1,965$ & $\$ 2,369$ & $\$ 3,100$ \\
\hline Toronto C07 & 1,885 & - & $\$ 2,176$ & $\$ 2,812$ & $\$ 3,242$ \\
\hline Toronto C08 & 1,885 & $\$ 1,866$ & $\$ 2,238$ & $\$ 3,111$ & $\$ 4,669$ \\
\hline Toronto C09 & 1,885 & - & $\$ 2,302$ & $\$ 4,141$ & $\$ 4,600$ \\
\hline Toronto C10 & 1,885 & $\$ 1,700$ & $\$ 2,209$ & $\$ 2,989$ & - \\
\hline Toronto C11 & 1,885 & - & $\$ 1,833$ & $\$ 2,683$ & $\$ 2,325$ \\
\hline Toronto C12 & 1,885 & - & $\$ 2,350$ & $\$ 3,404$ & $\$ 3,150$ \\
\hline Toronto $\mathrm{C} 13$ & 1,885 & $\$ 1,690$ & $\$ 1,996$ & $\$ 2,404$ & - \\
\hline Toronto C14 & 1,885 & $\$ 1,800$ & $\$ 2,124$ & $\$ 2,717$ & $\$ 3,017$ \\
\hline Toronto C15 & 1,885 & $\$ 1,676$ & $\$ 2,031$ & $\$ 2,618$ & $\$ 3,113$ \\
\hline Toronto East & 1,885 & $\$ 1,536$ & $\$ 1,954$ & $\$ 2,203$ & $\$ 2,635$ \\
\hline Toronto E01 & 1,885 & - & $\$ 2,271$ & $\$ 2,835$ & $\$ 5,000$ \\
\hline Toronto E02 & 1,885 & $\$ 1,498$ & $\$ 2,266$ & $\$ 2,750$ & - \\
\hline Toronto E03 & 1,885 & - & $\$ 1,769$ & $\$ 2,125$ & - \\
\hline Toronto E04 & 1,885 & - & $\$ 1,874$ & $\$ 1,978$ & $\$ 2,200$ \\
\hline Toronto E05 & 1,885 & - & $\$ 1,803$ & $\$ 2,262$ & $\$ 2,395$ \\
\hline Toronto E06 & 1,885 & $\$ 1,400$ & $\$ 1,850$ & $\$ 2,017$ & $\$ 3,800$ \\
\hline Toronto E07 & 1,885 & - & $\$ 1,799$ & $\$ 2,089$ & $\$ 2,150$ \\
\hline Toronto E08 & 1,885 & - & $\$ 1,817$ & $\$ 2,088$ & $\$ 2,083$ \\
\hline Toronto E09 & 1,885 & $\$ 1,618$ & $\$ 1,923$ & $\$ 2,207$ & - \\
\hline Toronto E10 & 1,885 & - & - & - & - \\
\hline Toronto E11 & 1,885 & - & $\$ 1,675$ & $\$ 1,925$ & - \\
\hline
\end{tabular}


APPENDIX I: WARD 18 OWNERSHIP ANALYSIS

\begin{tabular}{|c|c|c|c|c|c|c|c|c|}
\hline & $\begin{array}{l}\text { Affordable } \\
\text { Purchase } \\
\text { Price }\end{array}$ & Detached & $\begin{array}{l}\text { Semi } \\
\text { detached }\end{array}$ & $\begin{array}{l}\text { Condominium } \\
\text { Townhouse }\end{array}$ & $\begin{array}{l}\text { Condominium } \\
\text { apartment }\end{array}$ & $\begin{array}{l}\text { Row/Town } \\
\text { house }\end{array}$ & $\begin{array}{l}\text { Co-apar } \\
\text { tment }\end{array}$ & $\begin{array}{l}\text { Co- } \\
\text { ownership } \\
\text { apartment }\end{array}$ \\
\hline TREB Total & & $\$ 945,580$ & $\$ 755,707$ & $\$ 567,290$ & $\$ 554,497$ & $\$ 679,164$ & $\$ 736,875$ & $\$ 471,667$ \\
\hline City of Toronto Total & 391,800 & $\$ 1,145,892$ & $\$ 939,859$ & $\$ 652,787$ & $\$ 594,381$ & $\$ 860,920$ & $\$ 889,167$ & $\$ 471,667$ \\
\hline Toronto West & 391,800 & $\$ 1,002,126$ & $\$ 831,798$ & $\$ 581,058$ & $\$ 485,890$ & $\$ 745,883$ & $\$ 270,000$ & - \\
\hline Toronto W01 & 391,800 & $\$ 1,429,250$ & $\$ 1,063,000$ & $\$ 672,000$ & $\$ 647,631$ & $\$ 1,050,000$ & - & - \\
\hline Toronto W02 & 391,800 & $\$ 1,139,167$ & $\$ 997,778$ & $\$ 681,250$ & $\$ 655,000$ & $\$ 866,500$ & - & - \\
\hline Toronto W03 & 391,800 & $\$ 727,308$ & $\$ 838,585$ & $\$ 614,667$ & $\$ 432,800$ & - & - & - \\
\hline Toronto W04 & 391,800 & $\$ 782,983$ & $\$ 808,000$ & $\$ 540,250$ & $\$ 401,919$ & $\$ 600,000$ & - & - \\
\hline Toronto W05 & 391,800 & $\$ 779,500$ & $\$ 680,375$ & $\$ 482,150$ & $\$ 306,798$ & $\$ 667,500$ & - & - \\
\hline Toronto W06 & 391,800 & $\$ 886,310$ & $\$ 1,259,350$ & $\$ 708,288$ & $\$ 566,972$ & $\$ 850,000$ & $\$ 270,000$ & - \\
\hline Toronto W07 & 391,800 & $\$ 1,180,100$ & - & - & $\$ 1,700,000$ & $\$ 955,000$ & - & - \\
\hline Toronto W08 & 391,800 & $\$ 1,361,787$ & $\$ 725,000$ & $\$ 484,267$ & $\$ 503,289$ & $\$ 917,000$ & - & - \\
\hline Toronto W09 & 391,800 & $\$ 1,261,250$ & $\$ 835,000$ & $\$ 627,780$ & $\$ 440,958$ & $\$ 665,633$ & - & - \\
\hline Toronto W10 & 391,800 & $\$ 686,291$ & $\$ 720,000$ & $\$ 454,000$ & $\$ 347,579$ & $\$ 719,000$ & - & - \\
\hline Toronto Central & 391,800 & $\$ 1,808,074$ & $\$ 1,189,483$ & $\$ 833,800$ & $\$ 695,790$ & $\$ 1,217,042$ & $\$ 1,198,750$ & $\$ 471,667$ \\
\hline Toronto C01 & 391,800 & $\$ 1,975,296$ & $\$ 1,340,600$ & $\$ 969,663$ & $\$ 730,564$ & $\$ 1,257,813$ & - & - \\
\hline Toronto C02 & 391,800 & $\$ 1,400,000$ & $\$ 1,145,000$ & $\$ 1,097,000$ & $\$ 1,318,999$ & - & - & - \\
\hline Toronto C03 & 391,800 & $\$ 1,704,700$ & $\$ 1,104,333$ & - & $\$ 1,236,584$ & - & - & $\$ 390,000$ \\
\hline Toronto C04 & 391,800 & $\$ 1,835,333$ & - & $\$ 679,000$ & $\$ 665,482$ & - & - & - \\
\hline Toronto C06 & 391,800 & $\$ 1,179,500$ & - & - & $\$ 539,042$ & - & - & - \\
\hline Toronto C07 & 391,800 & $\$ 1,516,170$ & $\$ 751,000$ & $\$ 572,500$ & $\$ 609,597$ & - & - & - \\
\hline Toronto C08 & 391,800 & - & $\$ 1,559,333$ & $\$ 815,000$ & $\$ 606,765$ & $\$ 1,330,000$ & - & $\$ 320,000$ \\
\hline Toronto C09 & 391,800 & $\$ 2,550,375$ & $\$ 805,000$ & - & $\$ 1,033,750$ & - & $\$ 1,198,750$ & $\$ 705,000$ \\
\hline Toronto C10 & 391,800 & $\$ 1,561,800$ & $\$ 2,400,000$ & $\$ 662,500$ & $\$ 740,250$ & $\$ 1,225,000$ & - & - \\
\hline Toronto C11 & 391,800 & $\$ 1,912,348$ & - & $\$ 427,500$ & $\$ 458,200$ & - & - & - \\
\hline Toronto C12 & 391,800 & $\$ 3,619,800$ & - & $\$ 1,136,000$ & $\$ 730,000$ & - & - & - \\
\hline Toronto C13 & 391,800 & $\$ 2,157,667$ & $\$ 778,000$ & - & $\$ 566,500$ & $\$ 738,000$ & - & - \\
\hline Toronto C14 & 391,800 & $\$ 1,699,833$ & - & $\$ 811,000$ & $\$ 606,957$ & $\$ 1,249,000$ & - & - \\
\hline Toronto C15 & 391,800 & $\$ 1,155,472$ & $\$ 841,275$ & $\$ 623,578$ & $\$ 559,931$ & - & - & - \\
\hline Toronto East & 391,800 & $\$ 886,624$ & $\$ 914,754$ & $\$ 560,788$ & $\$ 428,075$ & $\$ 738,542$ & - & - \\
\hline Toronto E01 & 391,800 & $\$ 1,153,667$ & $\$ 1,064,160$ & $\$ 806,500$ & $\$ 647,175$ & $\$ 940,400$ & - & - \\
\hline Toronto E02 & 391,800 & $\$ 1,232,278$ & $\$ 1,158,486$ & $\$ 792,000$ & $\$ 950,000$ & - & - & - \\
\hline Toronto E03 & 391,800 & $\$ 1,017,386$ & $\$ 903,000$ & - & $\$ 480,708$ & - & - & - \\
\hline Toronto E04 & 391,800 & $\$ 755,472$ & $\$ 619,333$ & $\$ 603,917$ & $\$ 367,685$ & $\$ 681,000$ & - & - \\
\hline Toronto E05 & 391,800 & $\$ 873,831$ & $\$ 655,000$ & $\$ 560,000$ & $\$ 428,148$ & $\$ 805,000$ & - & - \\
\hline Toronto E06 & 391,800 & $\$ 826,765$ & - & - & $\$ 636,100$ & - & - & - \\
\hline Toronto E07 & 391,800 & $\$ 856,033$ & $\$ 723,500$ & $\$ 584,667$ & $\$ 376,876$ & - & - & - \\
\hline Toronto E08 & 391,800 & $\$ 891,091$ & - & $\$ 517,750$ & $\$ 398,437$ & $\$ 777,500$ & - & - \\
\hline Toronto E09 & 391,800 & $\$ 745,845$ & $\$ 657,333$ & $\$ 486,000$ & $\$ 421,281$ & - & - & - \\
\hline Toronto E10 & 391,800 & $\$ 800,989$ & $\$ 651,967$ & $\$ 446,600$ & $\$ 313,850$ & $\$ 652,833$ & - & - \\
\hline
\end{tabular}


APPENDIX J: WARD 18 - RENTAL ANALYSIIS

\begin{tabular}{|c|c|c|c|c|c|}
\hline & $\begin{array}{l}\text { Affordable Purchase } \\
\text { Price }\end{array}$ & Bachelor & One Bedroom & Two Bedroom & Three Bedroom \\
\hline TREB Total & & $\$ 1,821$ & $\$ 2,143$ & $\$ 2,774$ & $\$ 3,366$ \\
\hline City of Toronto Total & 2,185 & $\$ 1,838$ & $\$ 2,196$ & $\$ 2,944$ & $\$ 3,679$ \\
\hline Toronto West & 2,185 & $\$ 1,550$ & $\$ 2,023$ & $\$ 2,603$ & $\$ 2,981$ \\
\hline Toronto W01 & 2,185 & $\$ 1,450$ & $\$ 2,121$ & $\$ 2,780$ & $\$ 4,350$ \\
\hline Toronto W02 & 2,185 & - & $\$ 2,162$ & $\$ 2,887$ & - \\
\hline Toronto W03 & 2,185 & - & $\$ 1,900$ & - & $\$ 2,700$ \\
\hline Toronto W04 & 2,185 & $\$ 1,617$ & $\$ 1,882$ & $\$ 2,279$ & $\$ 3,350$ \\
\hline Toronto W05 & 2,185 & - & $\$ 1,957$ & $\$ 2,055$ & $\$ 2,000$ \\
\hline Toronto W06 & 2,185 & - & $\$ 2,093$ & $\$ 2,885$ & - \\
\hline Toronto W07 & 2,185 & - & $\$ 2,442$ & $\$ 3,050$ & - \\
\hline Toronto W08 & 2,185 & - & $\$ 1,957$ & $\$ 2,427$ & $\$ 2,625$ \\
\hline Toronto W09 & 2,185 & - & $\$ 1,750$ & $\$ 2,675$ & - \\
\hline Toronto W10 & 2,185 & - & $\$ 1,777$ & $\$ 2,131$ & $\$ 1,850$ \\
\hline Toronto Central & 2,185 & $\$ 1,857$ & $\$ 2,241$ & $\$ 3,080$ & $\$ 3,910$ \\
\hline Toronto C01 & 2,185 & $\$ 1,877$ & $\$ 2,319$ & $\$ 3,312$ & $\$ 4,330$ \\
\hline Toronto C02 & 2,185 & $\$ 1,913$ & $\$ 2,508$ & $\$ 4,063$ & $\$ 5,486$ \\
\hline Toronto C03 & 2,185 & $\$ 1,650$ & $\$ 2,131$ & $\$ 2,848$ & $\$ 2,500$ \\
\hline Toronto C04 & 2,185 & - & $\$ 2,028$ & $\$ 2,600$ & $\$ 2,948$ \\
\hline Toronto C06 & 2,185 & - & $\$ 1,965$ & $\$ 2,369$ & $\$ 3,100$ \\
\hline Toronto C07 & 2,185 & - & $\$ 2,176$ & $\$ 2,812$ & $\$ 3,242$ \\
\hline Toronto C08 & 2,185 & $\$ 1,866$ & $\$ 2,238$ & $\$ 3,111$ & $\$ 4,669$ \\
\hline Toronto C09 & 2,185 & - & $\$ 2,302$ & $\$ 4,141$ & $\$ 4,600$ \\
\hline Toronto C10 & 2,185 & $\$ 1,700$ & $\$ 2,209$ & $\$ 2,989$ & - \\
\hline Toronto C11 & 2,185 & - & $\$ 1,833$ & $\$ 2,683$ & $\$ 2,325$ \\
\hline Toronto C12 & 2,185 & - & $\$ 2,350$ & $\$ 3,404$ & $\$ 3,150$ \\
\hline Toronto C13 & 2,185 & $\$ 1,690$ & $\$ 1,996$ & $\$ 2,404$ & - \\
\hline Toronto C14 & 2,185 & $\$ 1,800$ & $\$ 2,124$ & $\$ 2,717$ & $\$ 3,017$ \\
\hline Toronto C15 & 2,185 & $\$ 1,676$ & $\$ 2,031$ & $\$ 2,618$ & $\$ 3,113$ \\
\hline Toronto East & 2,185 & $\$ 1,536$ & $\$ 1,954$ & $\$ 2,203$ & $\$ 2,635$ \\
\hline Toronto E01 & 2,185 & - & $\$ 2,271$ & $\$ 2,835$ & $\$ 5,000$ \\
\hline Toronto E02 & 2,185 & $\$ 1,498$ & $\$ 2,266$ & $\$ 2,750$ & - \\
\hline Toronto E03 & 2,185 & - & $\$ 1,769$ & $\$ 2,125$ & - \\
\hline Toronto E04 & 2,185 & - & $\$ 1,874$ & $\$ 1,978$ & $\$ 2,200$ \\
\hline Toronto E05 & 2,185 & - & $\$ 1,803$ & $\$ 2,262$ & $\$ 2,395$ \\
\hline
\end{tabular}




\begin{tabular}{|l|l|l|l|l|l|}
\hline Toronto E06 & $\mathbf{2 , 1 8 5}$ & $\$ 1,400$ & $\$ 1,850$ & $\$ 2,017$ & $\$ 3,800$ \\
\hline Toronto E07 & $\mathbf{2 , 1 8 5}$ & - & $\$ 1,799$ & $\$ 2,089$ & $\$ 2,150$ \\
\hline Toronto E08 & $\mathbf{2 , 1 8 5}$ & - & $\$ 1,817$ & $\$ 2,088$ & $\$ 2,083$ \\
\hline Toronto E09 & $\mathbf{2 , 1 8 5}$ & $\$ 1,618$ & $\$ 1,923$ & $\$ 2,207$ & - \\
\hline Toronto E10 & $\mathbf{2 , 1 8 5}$ & - & - & - & - \\
\hline Toronto E11 & $\mathbf{2 , 1 8 5}$ & - & $\$ 1,675$ & $\$ 1,925$ & - \\
\hline
\end{tabular}




\section{BIBLIOGRAPHY}

Aird Berlis. (2017). The Development Approval Process Housing Matters. Retrieved from http://torontohousingmatters.com/slides/aug2017pepino.pdf

Ann Mcafee. (2006). Canada Mortgage and Housing Corporation | The Canadian Encyclopedia. Retrieved from https://www.thecanadianencyclopedia.ca/en/article/canada-mortgage-andhousing-corporation

Bank of Canada. (2019). Daily Digest - Bank of Canada. Retrieved from https://www.bankofcanada.ca/rates/daily-digest/

Bank of Montreal (BMO). (2018). New Mortgage Rules | Mortgages | BMO. Retrieved from https://www.bmo.com/main/personal/mortgages/new-mortgage-rules-stress-test/

Bertaud, A. (2018). Rating Middle-Income Housing Affordability. 15 th Annual Demographia International Housing Affordability Survey. Retrieved from http://www.demographia.com/dhi.pdf

BlackRock Asset Management Canada Limited. (2014). BlackRock Survey: Canadians Prioritize Long-Term Financial Goals, but Their Short-Term Actions Are a Barrier to Reaching Them. Retrieved from http://www.marketwired.com/press-release/blackrock-survey-canadiansprioritize-long-term-financial-goals-but-their-short-term-1962637.htm

Cai, Z. (2017). ANALYZING MEASUREMENTS OF HOUSING AFFORDABILITY. Retrieved from https://search-proquest-com.ezproxy.lib.ryerson.ca/docview/1939076512?pqorigsite $=$ summon

Cambridge Dictionary. (n.d.). AFFORDABILITY | meaning in the Cambridge English Dictionary. Retrieved from https://dictionary.cambridge.org/dictionary/english/affordability

Canada Mortgage and Housing Corporation. (2016). Rental Market Report-Greater Toronto Area-Date Released-2016. Retrieved from www.cmhc.ca/housingmarketinformation.

Canada Mortgage and Housing Corporation. (2017). Rental Market Report-Greater Toronto Area-Date. Retrieved from www.cmhc.ca/housingmarketinformation.

Canada Mortgage and Housing Corporation. (2019). Housing Market Information Portal. Retrieved from https://www03.cmhc-schl.gc.ca/hmip-pimh/en\#Profile/2270/3/Toronto

Canada Mortgage and Housing Corporation (CMHC). (2018a). About Affordable Housing in Canada. Retrieved from https://www.cmhc-schl.gc.ca/en/developing-andrenovating/develop-new-affordable-housing/programs-and-information/about-affordablehousing-in-canada

Canada Mortgage and Housing Corporation (CMHC). (2018b). CMHC Third Quarter 2018 Quarterly Financial Report | CMHC. Retrieved from https://www.cmhc-schl.gc.ca/en/medianewsroom/news-releases/2018/cmhc-continues-to-deliver-for-canadians

Canada Mortgage and Housing Corporation (CMHC). (2018c). Housing Market Information Portal. Retrieved from https://www03.cmhc-schl.gc.ca/hmippimh/en/TableMapChart/Table?Tableld=1.1.4.6\&Geographyld=2270\&GeographyTypeld=3 \&DisplayAs=Table\&GeograghyName=Toronto\#All 
Canada Mortgage and Housing Corporation (CMHC). (2019). CMHC's Story. Retrieved from https://www.cmhc-schl.gc.ca/en/about-cmhc/cmhcs-story

Canada Without Poverty. (2019). The Right to Housing | Canada Without Poverty. Retrieved from http://www.cwp-csp.ca/poverty/a-human-rights-violation/the-right-to-housing/

Canadian Mortgage and Housing Corporation (CMHC). (2019). Housing Market Assessment (HMA). Retrieved from https://www03.cmhc-schl.gc.ca/hmippimh/en/TableMapChart/HMAMethodology

Charlotte Balluch, Alexis Beale, Jessica Brodeur, Tessa Chapman, Davin McCully, Michael Niezgoda, ... Vickey Simovic. (2018). Diversifying Density: Re-Thinking Toronto's Yellowbelt.

Christopher Pollon, C. C. and C. W. (2017). The Big Give: How Owners Got Rich, and Renters Didn't | The Tyee. Retrieved from https://thetyee.ca/News/2017/02/22/The-Big-Give/

City of Toronto. (2006). Toronto Official Plan Office Consolidation - June 2015. Retrieved from https://www.toronto.ca/wp-content/uploads/2017/11/99b3-cp-official-plan-volume-1consolidation.pdf

City of Toronto. (2017a). 2016 Census Backgrounder Income 201709 14. Retrieved from http://www12.statcan.gc.ca/census-recensement/2016/ref/dict/

City of Toronto. (2017b). Toronto Housing Charter Opportunity for All. Retrieved from https:/www.toronto.ca/wp-content/uploads/2017/11/8eca-2016-TOHousingCharter.pdf

City of Toronto. (2018a). 2018 RENTAL HOUSING MARKET CONDITIONS IN TORONTO. Retrieved from https://www.toronto.ca/legdocs/mmis/2018/td/bgrd/backgroundfile112710.pdf

City of Toronto. (2018b). Fact Sheet: 2018 Development Charges Bylaw Review. Retrieved from https://www.toronto.ca/wp-content/uploads/2018/04/8e62-DC-Review-Fact-SheetApril-27.pdf

City of Toronto. (2019a). Current City of Toronto Average Market Rents \&amp; Utility Allowances. Retrieved from https://www.toronto.ca/community-people/communitypartners/social-housing-providers/affordable-housing-operators/current-city-of-torontoaverage-market-rents-and-utility-allowances/

City of Toronto. (2019b). Official Plan and Zoning By-law Amendment. Retrieved from https://www.toronto.ca/city-government/planning-development/application-formsfees/building-toronto-together-a-development-guide/official-plan-and-zoning-by-lawamendment/

City of Toronto. (2019c). Property Tax Calculator. Retrieved from https://www.toronto.ca/services-payments/property-taxes-utilities/property-tax/property-taxcalculator/property-tax-calculator/

City of Toronto. (2019d). Ward Profiles. Retrieved from https://www.toronto.ca/citygovernment/data-research-maps/neighbourhoods-communities/ward-profiles/

Clayton, F. A. (2015). Demographic Update-Millennials in the Greater Golden Horseshoe in Mid 2015. Retrieved from www.ryerson.ca/cur 
Clayton, F., Petramala, D., Researcher, M. A. S., \& Amborski, D. (2018). Action Plan for Improving Housing Affordability in the Greater Golden Horseshoe Policy Commentary. Retrieved from https://www.cmhc-schl.gc.ca/odpub/pdf/69262.pdf?fr=1522467180028.

Cohrs, A. (2014). Involving private sector developers: building affordable rental housing in the City of Toronto | Digital Repository. Retrieved from https://digital.library.ryerson.ca/islandora/object/RULA:2809

David F Clapham, William Clark, and K. G. (2012). The SAGE Handbook of Housing Studies. Retrieved from https://ebookcentral-proquestcom.ezproxy.lib.ryerson.ca/lib/ryerson/detail.action?docID=1000645

David Hulchanski, J. (2003). What Factors Shape Canadian Housing Policy? The Intergovernmental Role in Canada's Housing System. Retrieved from https://homelesshub.ca/sites/default/files/4kfk3iwr.pdf

Government of Canada. (2018). Canada's National Housing Strategy A place to call home 2 NATIONAL HOUSING STRATEGY. Retrieved from https://www.placetocallhome.ca/pdfs/Canada-National-Housing-Strategy.pdf

Hogue, R. (2019). FOCUS ON CANADA'S HOUSING MARKET. Retrieved from http://www.rbc.com/economics/economic-reports/pdf/canadianhousing/Home_Ownership_Feb2019.pdf

Hou, F. (2010). Analytical Studies Branch Research Paper Series Homeownership over the Life Course of Canadians: Evidence from Canadian Censuses of Population. Retrieved from https://www150.statcan.gc.ca/n1/pub/11f0019m/2010325/part-partie1-eng.htm\#archived

Janet Mcfarland. (2017). Census 2016: Toronto housing affordability now worse than Vancouver - The Globe and Mail. Retrieved from https://www.theglobeandmail.com/report-onbusiness/census-2016-residents-in-toronto-area-struggle-the-most-with-homeaffordability/article36717906/

Julie Mah. (2009). Can Inclusionary Zoning Help Address the Shortage of Affordable Housing in Toronto? Retrieved from https://books-scholarsportalinfo.ezproxy.lib.ryerson.ca/uri/ebooks/ebooks0/gibson_cppc/2010-08-06/5/10360673

Loans Canada. (2019). How To Stress Test Your Mortgage 2018 | Loans Canada. Retrieved from https://loanscanada.ca/mortgage/stress-test-mortgage-2018/

Melanie D. Jewkes and Lucy M. Delgadillo. (2010). Housing Affordability Measures Multiple indices for measuring housing affordability exist. Retrieved from https://afcpe.org/assets/pdf/volume_21_issue_1/jewkes_delgadillo.pdf

Merriam Webster. (n.d.). Affordability | Definition of Affordability by Merriam-Webster. Retrieved from https://www.merriam-webster.com/dictionary/affordability

Ministry of Finance. (2017a). Newsroom : Ontario's Fair Housing Plan. Retrieved from https://news.ontario.ca/mof/en/2017/04/ontarios-fair-housing-plan.html

Ministry of Finance. (2017b). Ontario Population Projections Update. Retrieved from https://www.fin.gov.on.ca/en/economy/demographics/projections/

Ministry of Municipal Affairs and Housing. (2014). Provincial Policy Statement, 2014. Retrieved 
from http://www.mah.gov.on.ca/Page10679.aspx

Ministry of Municipal Affairs and Housing. (2017). Places to Grow - Growth Plan 2017. Retrieved from

http://placestogrow.ca/index.php?option=com_content\&task=view\&id=430\&ltemid=14

NBLC. (2016). Understanding the Cost of Incentives City of Mississauga Affordable Housing Program NBLC. Retrieved from https://www7.mississauga.ca/documents/pb/main/2016/appendixoneOct2016.pdf

Nepstic. (2018). Best Cities for Millennials 2018 | Nestpick World Ranking. Retrieved from https://www.nestpick.com/millennial-city-ranking-2018/

Office of the United Nations High Commissioner for Human Rights. (2014). The Right to Adequate Housing. Retrieved from https://www.ohchr.org/Documents/Publications/FS21_rev_1_Housing_en.pdf

Official Data Foundation. (2019). CA $\$ 1$ in $1984 \rightarrow 2018$ | Canada Inflation Calculator. Retrieved from http://www.in2013dollars.com/1984-CAD-in-2018?amount=1

Ontario Real Estate Association (OREA). (2019). Insights Real Estate in Ontario. Retrieved March 23, 2019, from https://www.orea.com/Resources-and-Forms/Research-andData/Insights-Real-Estate-in-Ontario

Ormiston, J. L. (2014). AFFORDABLE HOMEOWNERSHIP: SOLUTIONS FOR ALLEVIATING MISSISSAUGA'S AFFORDABLE HOUSING ISSUE. Retrieved from https://digital.library.ryerson.ca/islandora/object/RULA\%3A6455/datastream/OBJ/view

Oxford Dictionaries. (n.d.). affordability | Definition of affordability in English by Oxford Dictionaries. Retrieved from https://en.oxforddictionaries.com/definition/affordability

Parliament of Canada. (n.d.). Private Member's Bill C-400 (41-1) - First Reading - Secure, Adequate, Accessible and Affordable Housing Act - Parliament of Canada. Retrieved from http://www.parl.ca/DocumentViewer/en/41-1/bill/C-400/first-reading/page-33\#3

Peter Zimonjic. (2017). Liberals detail \$40B for 10-year national housing strategy, introduce Canada Housing Benefit | CBC News. Retrieved from https://www.cbc.ca/news/politics/housing-national-benefit-1.4413615

Petramala, D., Researcher, M. S., Clayton, F., Butler, A., Mackaay, A., Quigg, A., \& Quigg, E. (2018). Centre for Urban Research and Land Development Millennials in the Greater Toronto and Hamilton Area: A Generation Stuck in Apartments? Retrieved from https://www.ryerson.ca/content/dam/cur/pdfs/policycommentaries/CUR_Research_Report_ Millennial_Housing_GTHA_May_22.pdf

Real Estate Association (CREA). (2019). National Statistics. Retrieved March 23, 2019, from http://creastats.crea.ca/natl/

Social Justice Tribunals Ontario. (2019). LTB | 2019 Rent Increase Guideline. Retrieved March 30, 2019, from http://www.sjto.gov.on.ca/documents/tb/Brochures/2019 Rent Increase Guideline (EN).html

Statistics Canada. (2017). Statistics Canada: Canada's national statistical agency. Retrieved from https://www150.statcan.gc.ca/t1/tbl1/en/cv.action?pid=1110019301 
Stone, M. E. (2004). Shelter Poverty: The Chronic Crisis of Housing Affordability Part of the Housing Law Commons, and the Social Welfare Commons. Retrieved from http://scholarworks.umb.edu/nejpphttp://scholarworks.umb.edu/nejpp/vol20/iss1/16

Stone, M. E. (2006). From the SelectedWorks of Michael E. Stone What is Housing Affordability? The Case for the Residual Income Approach What Is Housing Affordability? The Case for the Residual Income Approach. Retrieved from http://works.bepress.com/michael_stone/5/

Toronto Real Estate Board (TREB). (2018). TREB Market Watch December 2018. Retrieved from http://www.trebhome.com/files/market-stats/market-watch/mw1812.pdf

Toronto Real Estate Board (TREB). (2019). TREB's fourth annual Market Year in Review Outlook Report. Retrieved from

http://communications3.torontomls.net/auth2/mediafiles/Market-Year-in-Review/pdf/2019YearlnReview_interactive_2Col.pdf

Toronto Region Board of Trade. (2018). THE CURRENT STATE OF HOUSING IN THE REGION. Retrieved from https://www.bot.com/Portals/0/Agenda For Growth_Housing Policy Playbook_FINAL_HR.pdf

United Nations Human Rights. (1966). OHCHR | International Covenant on Economic, Social and Cultural Rights. Retrieved from https://www.ohchr.org/en/professionalinterest/pages/cescr.aspx

United Nations Human Rights. (2019a). OHCHR | Special Rapporteur on adequate housing as a component of the right to an adequate standard of living, and on the right to nondiscrimination in this context. Retrieved from https://www.ohchr.org/EN/lssues/Housing/Pages/Housinglndex.aspx

United Nations Human Rights. (2019b). OHCHR | The Right to Adequate Housing Toolkit. Retrieved from https://www.ohchr.org/EN/lssues/Housing/toolkit/Pages/RighttoAdequateHousingToolkit.as $\mathrm{px}$

Webster, M. (n.d.). Housing | Definition of Housing by Merriam-Webster. Retrieved from https://www.merriam-webster.com/dictionary/housing

Wright, C., \& Hogue, R. (2018). HOUSING TRENDS AND AFFORDABILITY. Retrieved from http://www.rbc.com/economics/economic-reports/pdf/canadian-housing/house-dec2018.pdf

Young, R., \& Leuprecht, C. (2006). Municipal-Federal-Provincial Relations in Canada Edited by The State of the Federation 2004 ii Canadian Cataloguing in Publication Data. Retrieved from https://www.queensu.ca/iigr/sites/webpublish.queensu.ca.iigrwww/files/files/pub/archive/SO TF/StateFed04.pdf 


\section{GLOSSARY}

Rental housing is a building or related group of buildings containing one or more rented residential units, including vacant units that have been used for rented residential purposes, and units that are being or have last been used for rented residential purposes in equity cooperative or co-ownership housing, but does not include condominium-registered or life-lease units.

Affordable rental housing and affordable rents means housing where the total monthly shelter cost (gross monthly rent including utilities - heat, hydro and hot water - but excluding parking and cable television charges) is at or below one times the average City of Toronto rent, by unit type (number of Bedrooms), as reported annually by the Canada Mortgage and Housing Corporation.

Affordable ownership housing is housing which is priced at or below an amount where the total monthly shelter cost (mortgage principal and interest - based on a 25-year amortization, 10 percent down payment and the chartered bank administered mortgage rate for a conventional 5year mortgage as reported by the Bank of Canada at the time of application - plus property taxes calculated on a monthly basis) equals the average City of Toronto rent, by unit type, as reported annually by the Canada Mortgage and Housing Corporation. Affordable ownership price includes GST and any other mandatory costs associated with purchasing the unit.

Mid-range rents are the total monthly shelter costs which exceed affordable rents but fall below one and one-half times the average City of Toronto rent, by unit type, as reported annually by Canada Mortgage and Housing Corporation.

Social housing refers to rental housing units which are owned by a non-profit housing corporation, including housing provided by nonprofit housing co-operatives to their members, and which are produced or funded under government programs providing comprehensive funding or financing arrangements, whether or not in partnership with municipal government. 
